MILESTONES $1830-1930$ 


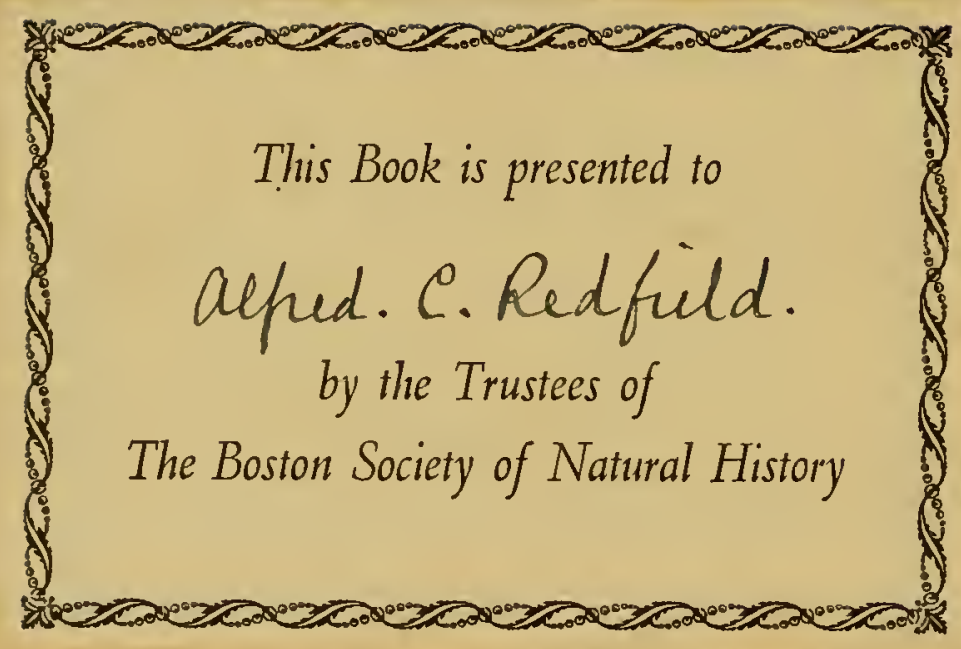




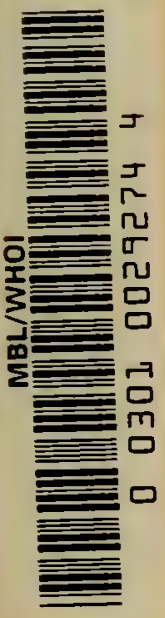





\section{THE BOSTON SOCIETY OF NATURAL HISTORY}


. 


\section{THE BOSTON SOCIETY OF NATURAL HISTORY

$$
\text { I830-1930 }
$$

The course of nature is the art of God.

EDWARD YOUNG
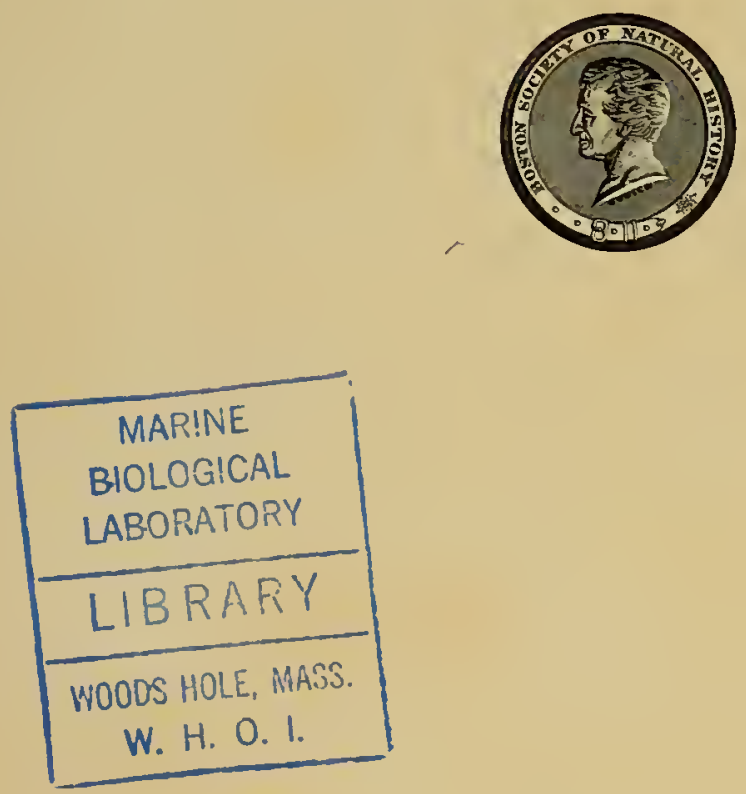

\section{BOSTON \\ Printed for the Society}

I 930 



\section{The Seal of the Society}

From the minutes of the meeting of the Boston Society of Natural History, held on November 3, 1841: VOTED, that the Society adopt as their corporate seal the one now presented, consisting of the profile of the head of Curier with the name of Curier beneath, surrounded by a belt containing the inscription of "Boston Society of Natural History," and that the custody thereof be committed to the Corresponding Secretary. 


\section{TO THE READER}

We trust that this simple story of a typical New England institution may cause you to share our pride in its past and our enthusiasm for its future.

The cost of this edition is borne by a few members of our Society.

\section{CHARLES H. TAYLOR}

Presidemt

February 9, 1930 


\section{TABLE OF CONTENTS}

I. Milestones 3

II. The Museum as it stands To-day $\quad 67$

III. Plans for the Future $\quad$ II3

This book is edited by Captain Percy R. Creed 


\section{LIST OF ILLUSTRATIONS}

Thomas Nuttall 2

Clarter 5

Benjamin D. Greene 9

George B. Emerson $\quad$ I2

Amos Bimey $\quad 15$

Augustus A. Gould $\quad 16$

Joln Collins Warren 19

Alexander von Himboldt 20

D. Hunuplireys Storer 23

Jeffries Wyman $\quad 27$

Louis Agassiz 28

Frederick W. Putnam II

Thomas T. Bonvé $\quad 32$

Samuel H. Scudder $\quad 37$

Alexander Agassiz $\quad 39$

Nathaniel E. Aturood 40

Thomas M. Brewer 43

Alphens Hyatt 44

Charles T. Jackson $\quad 47$

George Lincoln Goodale $\quad 48$

William Harmon Niles $\quad 5$ I

Charles Sedguick Minot $\quad 5^{2}$ 
Xii

Illustrations

Edward S. Morse

Jolm James Audubon

Plan showing Location of Musenm

A Corner of the Musenm Library

The Front Hall \& Main Staircase of Museum

72

Glover M. Allen

W. Cameron Forbes

Edw'ard Wigglesworth

$8_{5}$

View of the Main Gallery of Musemm

86

Charles W. Jolunson

Thomas Barbour

"Bald Eagle," selected as model by Audubon

IOI

"American Oyster Catcher," presented by Daniel Webster

102

Eggs, found and given by H. D. Thorean

107

Charles H. Taylor

108

The New Building

II 2

William J. Walker 


\section{I MILESTONES}




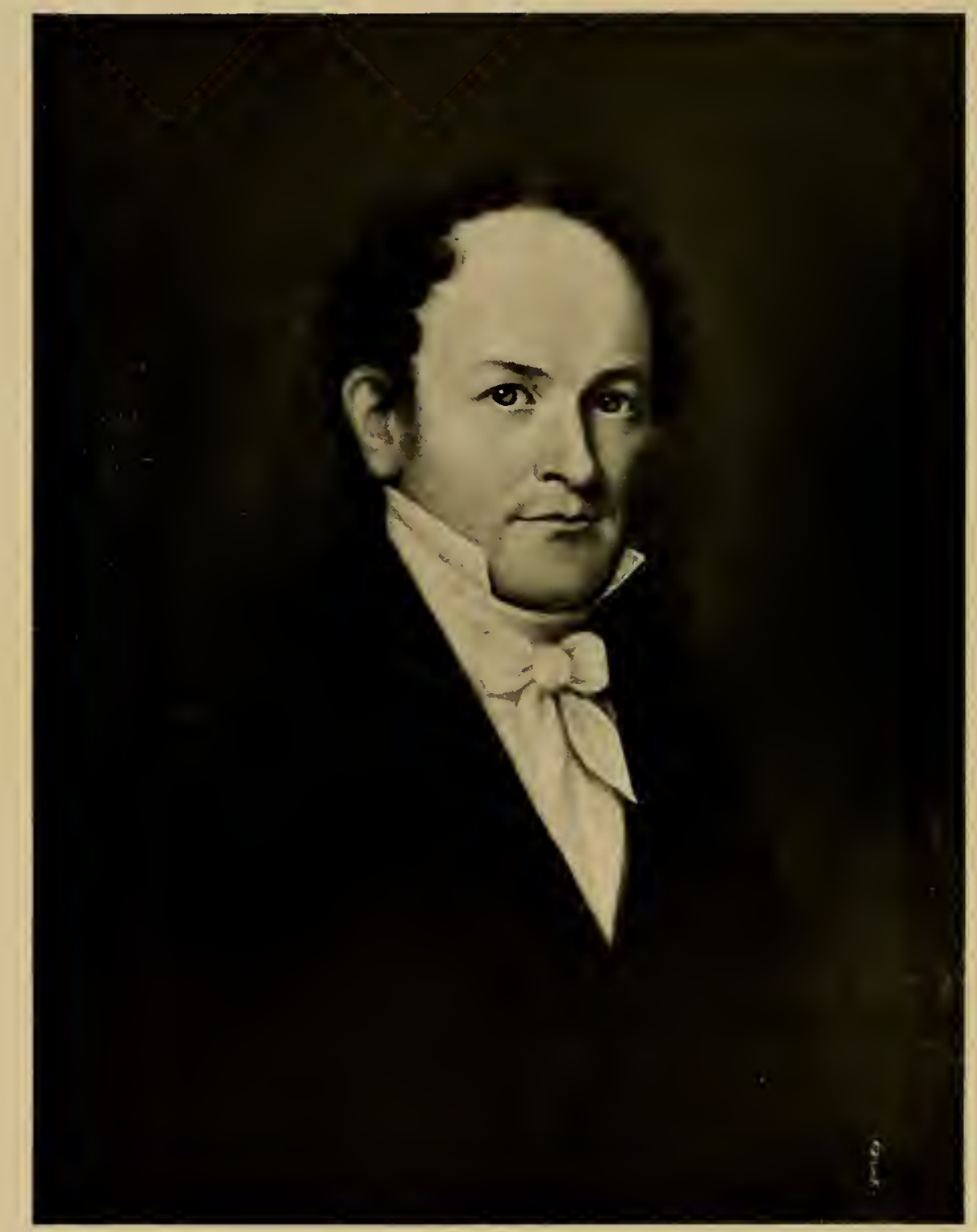

THOMAS NUTTALL

I $7^{86-1859 .}$ Original Mcmber.

Elected first president, May 13, 1830. Declined office because he regarded himself as only a transient resident (home was in England). 


\title{
THE BOSTON SOCIETY OF NATURAL HISTORY
}

\author{
I $830-1930$
}

\section{MILESTONES}

$\mathrm{O}_{\mathrm{r}}^{\mathrm{N}}$ N February 9, 1930, the Boston Society of Natural History passes its hundredth milestone along the road of years.

$$
\text { I } \delta_{30}
$$

THE first meeting of the Society was held at the house of Dr. 1 Walter Channing on February 9, 1830, and a committee was appointed. The members of the first committee are entitled to honorable mention and to our gratitude. Dr. Channing was made chairman and MIr. Simon E. Greene, secretary. They had for their colleagues Dr. George Hayward, Dr. John Ware, Mr. Edward Brooks, Dr. Amos Binney, and Mr. George B. Emerson.

Here is the personnel of the first office-bearers of the Society:

Thomas Nuttall, Presidext

George Hayward, First Vice-Presidext

John Ware, Second Vice-President

Gamaliel Bradford, Correspondixg Secretart

Theophilus Parsons, Recording Secietary

Simon E. Greene, Treasurer

Seth Bass, Librarian

\section{Curators}

Francis Alger

Amos Binney, Jr.

Edward Brooks

Walter Channing
George B. Emerson

Francis C. Gray

Benjamin D. Greene

Joseph W. McKean 
It would seem as though it were ordained that an ideal may be brought to realization only through the agony and self-sacrifice of its pioneers.

To this rule the story of the Boston Society of Natural History forms no exception. Here is an account by one of its original members of the atmosphere and circumstances through which the Society had to fight its way.

"At the time of the establishment of the Society, there was not, I believe, in New England, an institution deroted to the study of Natural History. There was not a college in New England, excepting Yale, where philosophical geology of the modern school was taught. 'There was not a work extant by a New England author which presumed to group the geological structure of any portion of our territory of greater extent than a county. There was not in existence a bare catalogue, to say nothing of a general history, of the animals of Massachusetts, of any class. 'There was not within our borders a single miseum of Natural History founded according to the requirements and based npon the system of modern science, nor a single journal advocating exclusively its interests.

"We were dependent chiefly upon books and authors foreign to New England for our knowledge of our own Zoölogy. 'There was no one among us who had anything like a general knowledge of the birds which fly about us, of the fishes which fill our waters, or of the lower tribes of animals that swarm both in air and in sea.

"Some few individuals there were, distinguished by high attainments in particular branches and who formed honorable exceptions to the indifference which prevailed, but there was no concentration of opinion or of knowledge, and no means of knowing how much or how little was known. The Laborers in Natural History icorticd alone aithout aid or encouragement from othersengaged in the same 
foluapos.

fimmonimalite

$O z^{3}$

Hessactursetts

$\neg \hat{\imath}$

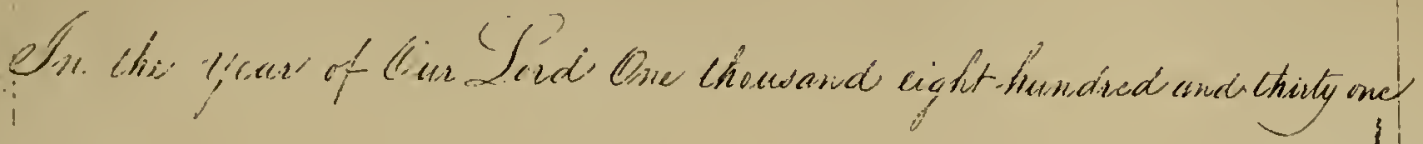

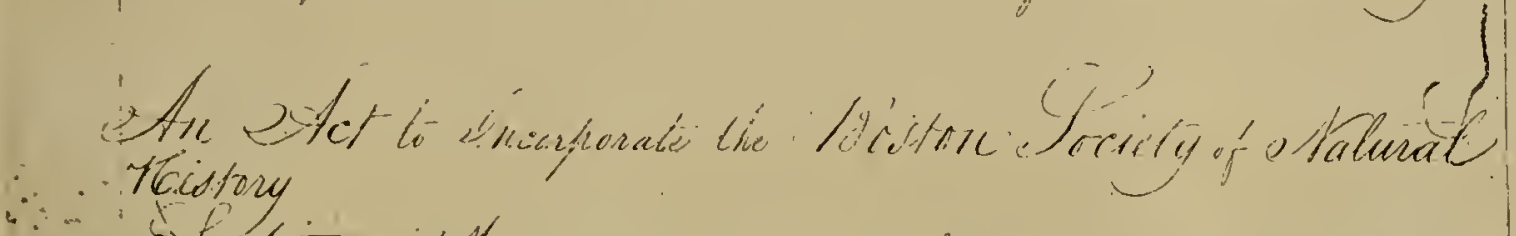

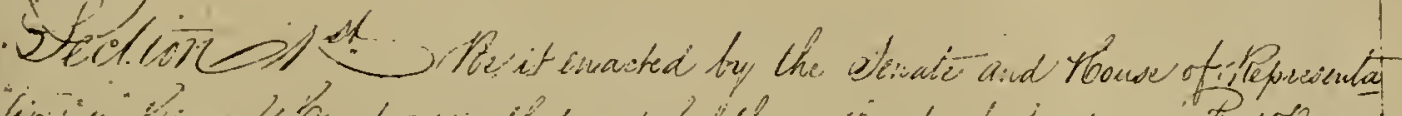

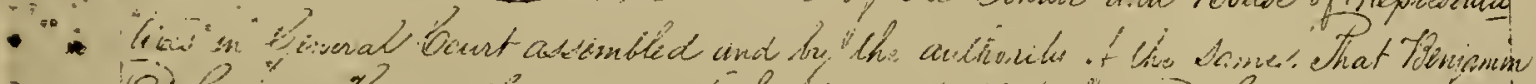

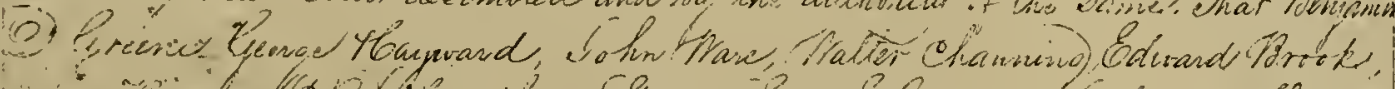

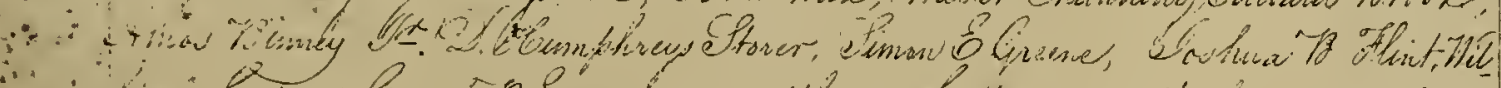

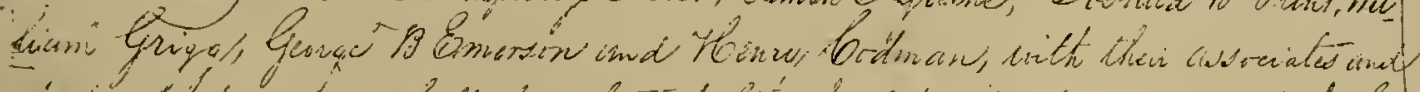

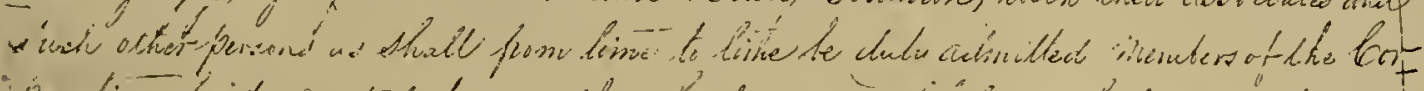

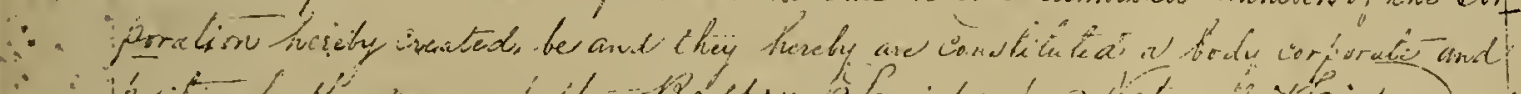

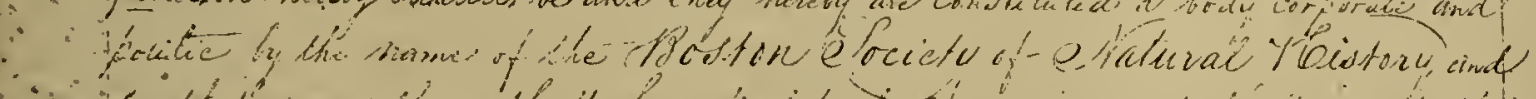

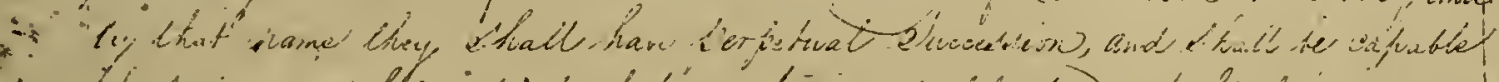

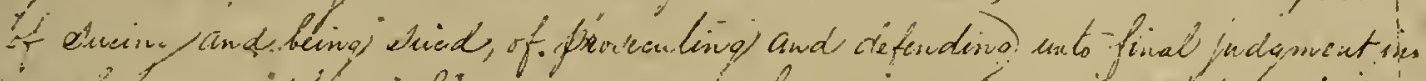

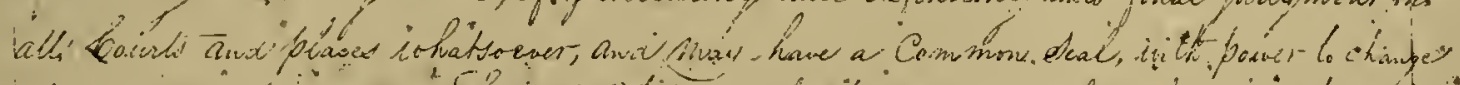

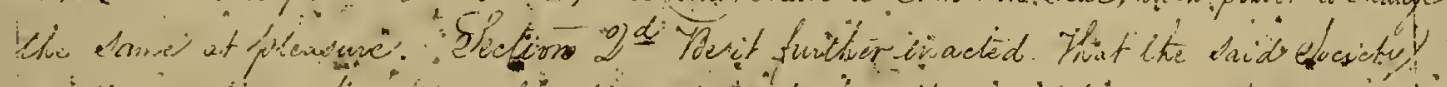

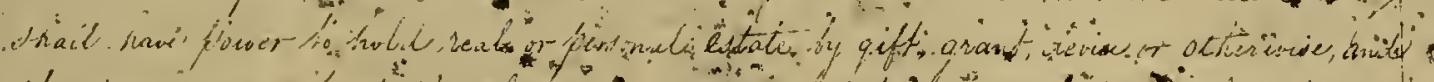

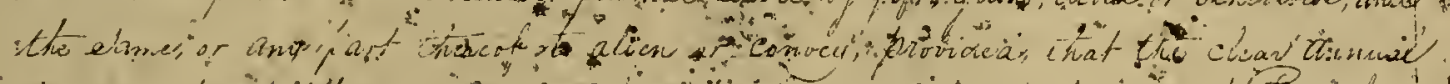

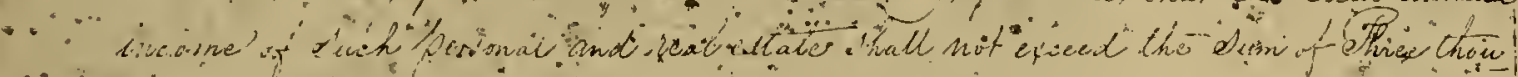

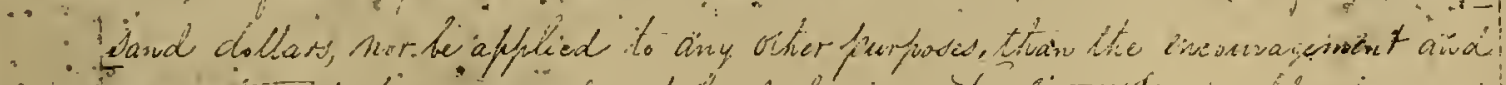

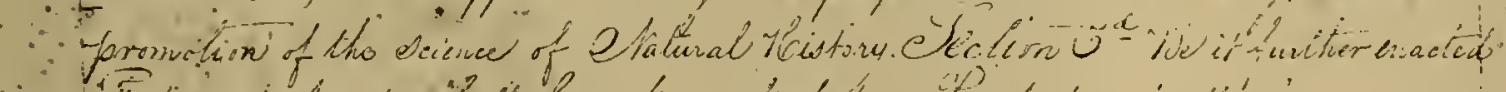

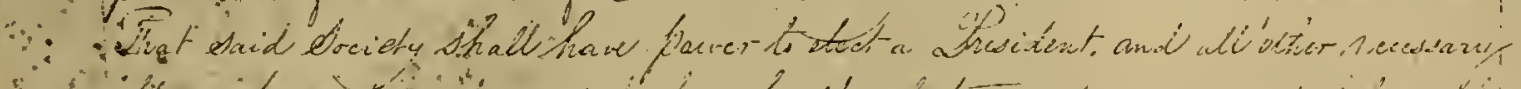

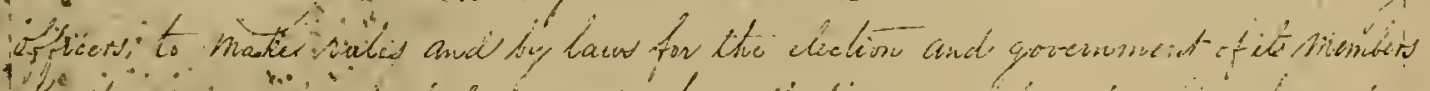

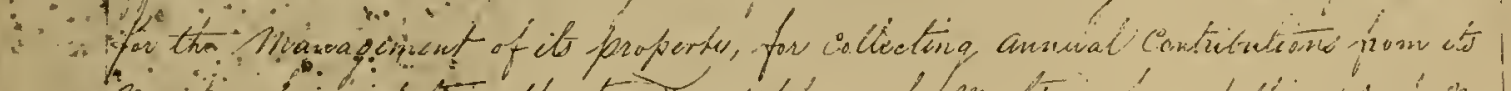

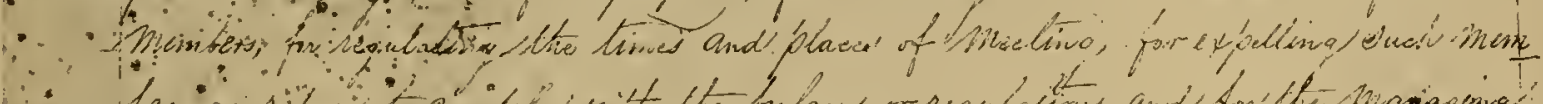

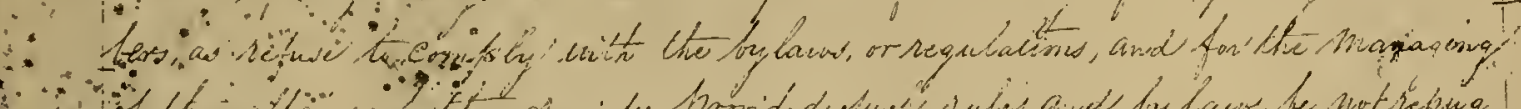

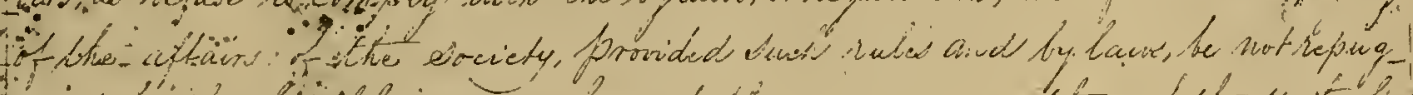

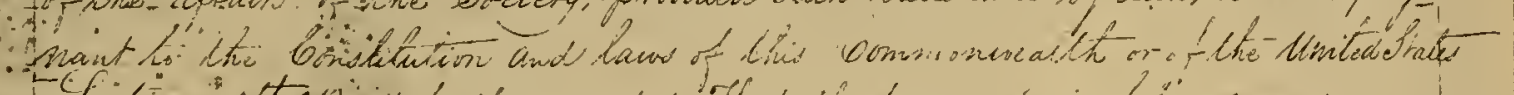

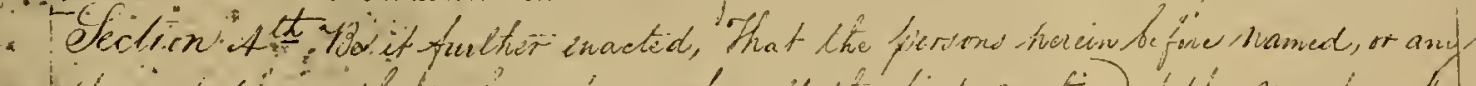

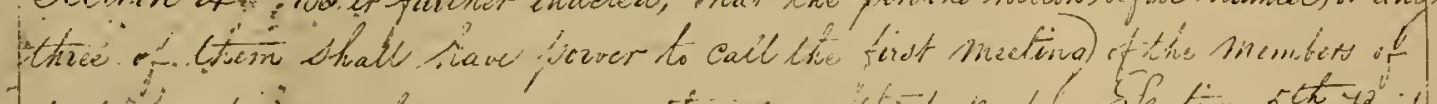

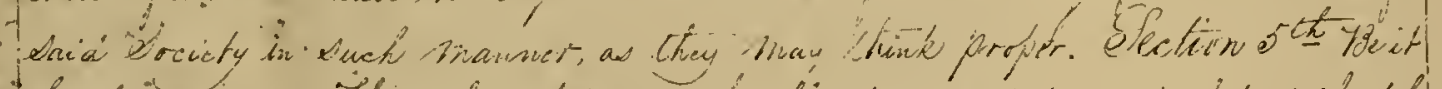

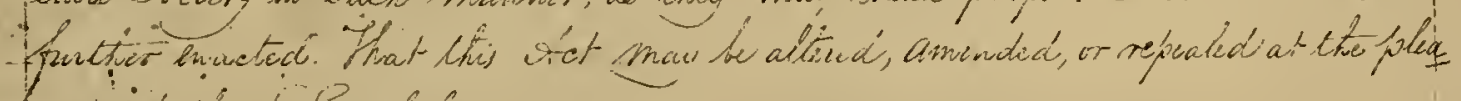

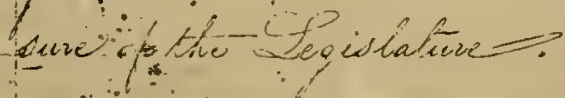

CHARTER OF THE BOSTON SOCIETY OF NATURAL HISTORY

Incorporated on the $25^{\text {th }}$ of February, i 83 I. 


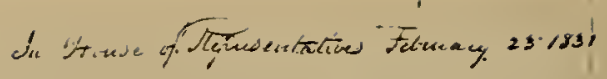

Posdex loto Lewe cax:

liy3.6abhow:

Areatio.

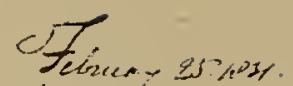

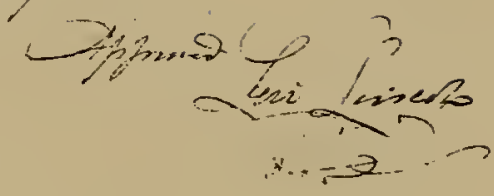

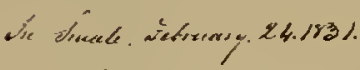

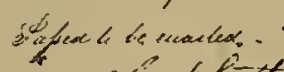

iam leftrop
Peritent 
pursuits, and without the approbation of the public mind, ichich regarded them as busy triflers."

The revolution in the public attitude and the absorbing interest of the present generation in "the course of Nature" are there for all to see. It is difficult for us to conceive the dispiriting conditions, so vividly described by our original member, the indifference and contempt which our naturalists had to face 100 years ago. Such, however, was the atmosphere in which the Boston Society of Natural History was born.

\section{The Third Milestone \\ I $\$ 33$}

TE problem of finance made an early demand on the attention scribed as "the hall over the Savings Bank in 'Tremont Street." A course of lectures for the winter 1833-34 was arranged and we are told that "the Committee considered it expedient to pay $\$ 15$ for each lecture." How far removed are we in these days from that scale of remuneration!

At one of the meetings of the Council of the Society in this year, the President, MIr. 13. D. Greene, expressed al strong desire that a fund of $\$ 5,000$ might be raised, the interest of which should be devoted to paying the rent bills incurred by the Society. He wished that we might feel independent and thought with such provision against indebtedness there would be no doubt of success. He then pledged himself ready to furnish $\$ 500$ for this object. Mr. Charles Amory likewise pledged himself to raise \$ 100 . "Nothing further," says the chronicler, "seems to have been done towards the creation of such a fund." Howerer, in spite of this lapse from generous grace, the faith and enthusiasm of its members kept the Society alive until 
an "angel" appeared on the scene. On a tablet in the vestibule of our Museum may be found the following inscription:

TO

AMIROSE. S. COURTIS

MIERCHANT OF BOSTON

WHOSE GENEROUS BEQUEST IN 1838 WAS

FOR TWENTY-FIVE YEAIS ITS CHIEF SUPPORT

THE BOSTON SOCIETY OF NATURAL, HISTORY

ON THE FIFTIETH ANNIVERSARY OF ITS FOUNDATION

GRATEFULLY INSCRIBES THIS TABLET

In his will he commended his bequest in the following terms:

"Finally, I request the recipients of the above bequeathed property to realize that no inconsiderable portion thereof has been gathered as the fruits of a laborious rocation, exercised through anxious days and sleepless nights; that it is given to them, in trust, nevertheless, to be expended so as to inure to the greatest advancement of sound education in the departments as above specified, and the public good. I request that its inrestment may be safely guarded; that its expenditure may be subject to the strictest economy; yet that it may be appropriated liberally where the objects aimed at justify an open hand, and camnot be afforded the cause of education and the public good at less expense."

Those who are familiar with the history of the Society will agree that the spirit of the touching request of its first great benefactor has governed the financial policy of the succeeding Trustees of the Society's funds. 


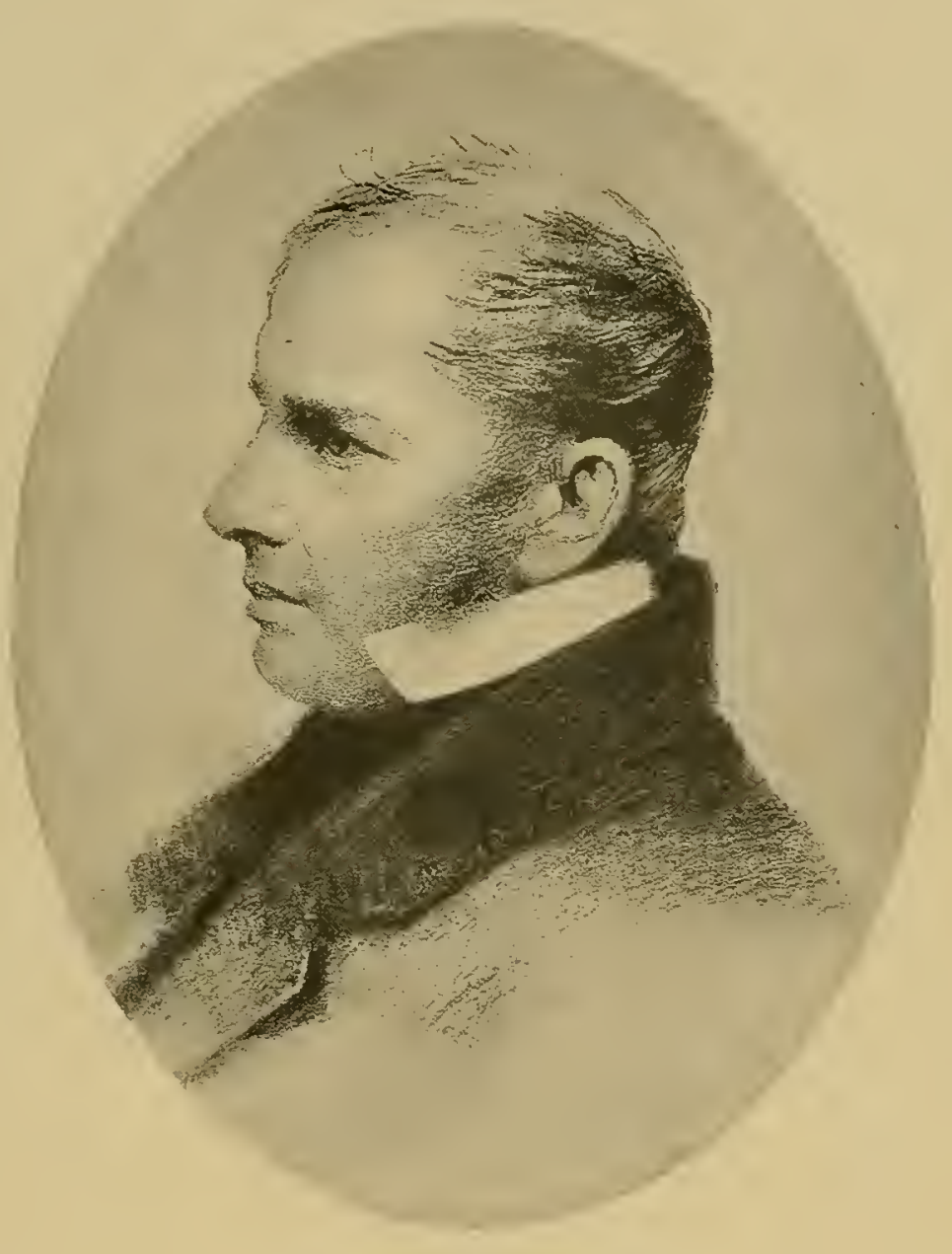

BENJAMIN D. GREENE
1793-1862. Original Member.

President, August 9, 1830, to May 3, 1837. Curator, May 13, 1830 , to September 2,1830 . His very complete herbarium and library were transferred to the Museum at his death. 


\section{The Seventh Milestone$$
\text { I } 837
$$

$\mathrm{N}$ this year our members came to the conclusion that a scientific I survey of the State of Massachusetts was "of the utmost desirability" and the President, Mr. George 13. Emerson, was deputed to memorialize the State Government on the subject. 'This he did, laying his memorial before Governor Everett "by whom it was most cordially and gracionsly received." In dne time the Govemor informed Mr. Emerson that the Legislature, both houses of which justly appreciated his memorial, had anthorized the Executive to appoint six proper persons to conduct the survey of the State and had passed an appropriation to corer the expenses thereof; and he requested that Mr. Emerson shonld suggest the names of such men as he thought competent for the work. The result was that the gentlemen appointed were almost entirelynamed by him. 'T'he Governor' desired that he should hold himself responsible for all the reports presented; but his friends in the Society, knowing his ability, were not satisficd except by his taking a more active part in the smrey; and he eventually divided the botany with Dr. Dewey, the doctor taking all other plants and Mr. Emerson the trees and shrubs. 'The report which he subseguently made to the I egislature was not only admirable in its scicntific features but was most charming from a literary point of view. It takes one ont with the writer into the fields and woods and makes the reader at once the interested student and the personal friend, so to speak, of the tree or shrub which the writer may be describing at the time. This report was made up from the observations and study of nine successive years, nearly three months of each of which he gave to the work, risiting all parts of the State in its prosecution. 


\section{Milestones}

Apart from these valuable serrices, Mr. Enerson who was, like Louis A gassiz, a noted Educator as well as Naturalist, prepared the well-known "Memorial of the American Institute of Instruction to the Massachusetts Legislature" and himself placed it in the hands of the Governor. 'The result of this course was the formation in April, 1837, of the Board of Education with Horace Mam, then President of the Senate, and a member of our Society, as its Secretary. The cause of Education took an new departure from this time forth, and the good effect of this action in which Mr. Emerson was prominent was incstimable. 'Thus, early in the history of the Society were the causes of Science and Education intimately associated in the persons and policies of its members.

As evidence of the position which the Society had won for itself fifty years ago stands the fact that instruction was given to a class of students from Boston University in Biology and Zoölogy: to a cliss of students from the Institute of Techology in Zoölogy and Paleontology: and to a special class of the teachers of the Public Schools in Zö̈logy. A part from these formal classes the laboratory room and its working collections were used by persons engaged in teaching or studying.

\section{The Eighteentlh Milestone$$
{ }_{1} \delta_{4} \delta
$$

$\Gamma_{\mathrm{N} A \text { pril, } 18+\tau, \mathrm{I}) \text { r. Samuel Cabot in behalf of a Committee to whom }}$ edifice for its purpose reported that the building in Mason Street known as the Massachusetts Medical College was for sale at a reasonable price and that after a thorough examination they judged it capable of being adapted perfectly to the wants of the Society. 'They, therefore, recommended its purchase and that the necessary 


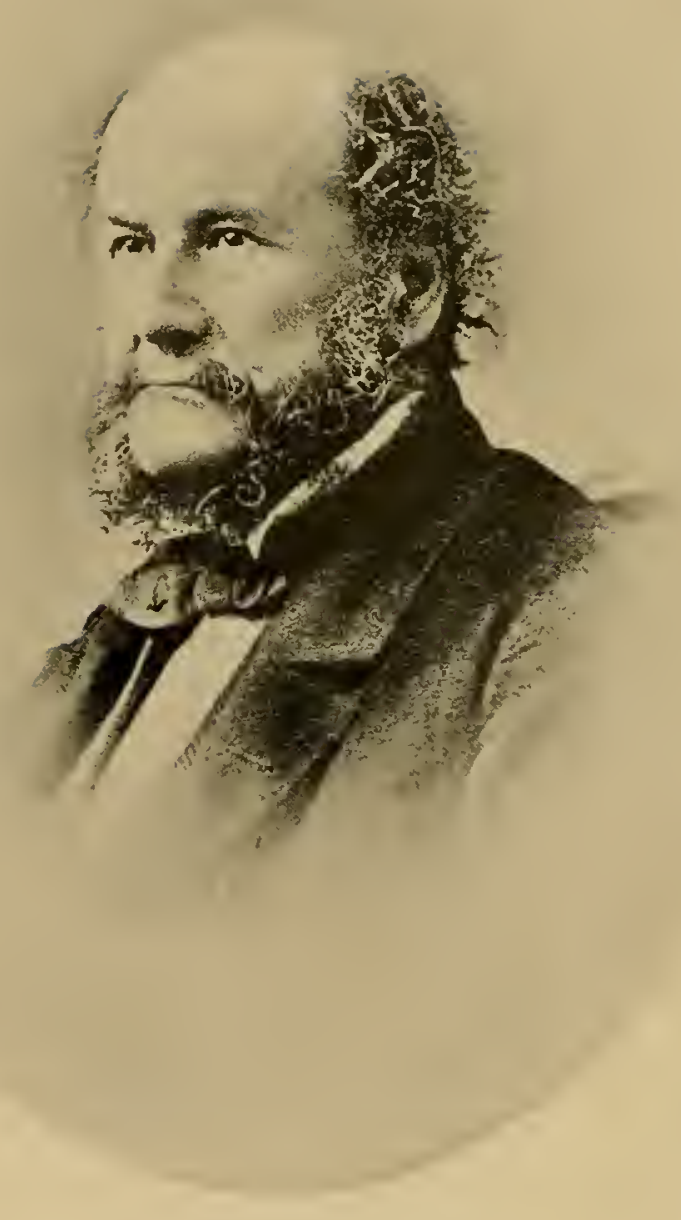

GEORGE B. EMERSON

1797-188 . Original Member.

President, May 3, 1837, to May 17, 1843. Curator, May 13, 1830, to May 3, 1837. 
alterations be made. Sufficient funds being available, this building was acquired, and on January 5,1848 , the Society met in its new home.

\section{The Thirtieth Milestone \\ I 860}

$\mathrm{B}^{\mathrm{r}}$ the year 1860 the Society had ontgrown its Mason Street

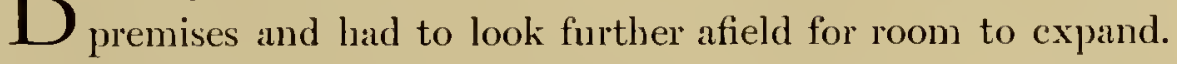
During the session of the Legislature in the winter of 1860-61 strenuous efforts were made by several members of the Society to obtain a grant of land from the State on which to build a Museum. These efforts proved successful and the site of the present building in Berkeley Street was given to the Society by the State, and for this gift the Society was as much indebted to Governor Andrew as to any other man.

Lonis Agassiz was also a redoubtable ally. He made a notable address in which he dwelt upon the desirableness of training the young, from their earliest years, to observe and study the works of God in Nature, urging this as among the best means of disciplining the intellectual powers, purifying the taste, and exalting the character. He insisted that the study of the plenomena of Nature was one of the most potent means of developing the human faculties, and that such education should be introduced into the schools as soon as practicable and made an indispensable part of all celucation. He insisted that the time when the importance of this view would be fully recognized was only so far remote as was necessary for the preparation of teachers capable of imparting this information. The whole force of his argument went to prove that such a Society as ours was of inestimable importance to aid teachers in their preparation. Agassiz felt with deep conviction that Natural 
History should be interwoven with the whole system of education and should become one of its essential features. He was not only a scientist of world-wide fame, but he was, equally, both by temperament and training an Educator. He said of himself:

"I have been a teacher since I was fifteen years of age. I am so now and I hope I shall continue to be all my life."

No man was better equipped to appreciate from practical experience the fundamental place of Natural History in Education. It is the earnest purpose of our Society to bring to fuller fruition the dreams and labors of Louis Agassiz by means of a bold programme designed to serve the cause of Education in New England.

The status in the public mind of the study of Natural History had by this time (1861) been raised from one of obscurity and derision to one of sympathetic interest, a progress which was largely due to the irresistible fascination with which Louis Agassiz and other naturalists of the day interpreted for laymen the fruits of their insatiable penetration into Nature's mysteries. 'The then President of the Society, Professor Wyman, thus outlined the Society's standing and functions:

"We have recently set forth our claim upon the community for patronage. It should be remembered that the public, though it does not formally set forth its claims upon us, has them, and with a deeper interest in the study of Nature than has been known before, judges us with a severer scrutiny and by a higher standard than at any previous period. So long as we make our collections useful and our studies conducive to the public good, and thus show ourselves faithful to our trusts, we are justified in the belief that we may confidently expect to receive hereafter every necessary support and encouragement."

'The impact of the Civil War on the Society is thus described by 


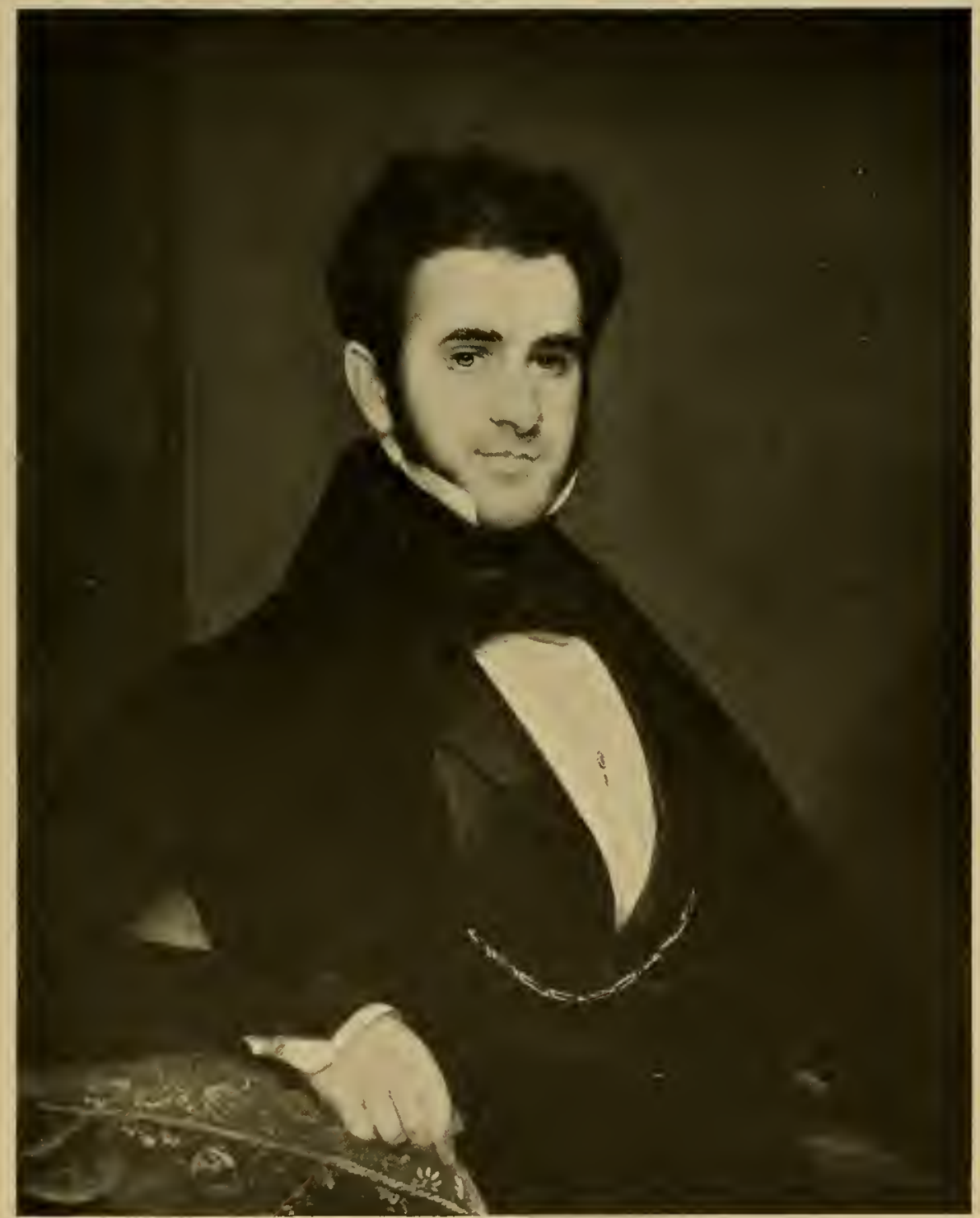

AMOS BINNEY

$$
\text { 1803-1847. Original Member. }
$$

President, May 17, 1843, to May 5, 1847. Curator, May 13, 1830, to May 2, 1832. Treasurer, May 2, 1832, to May 7, 1834. Second Vice-President, May 3, 1837, to May 5, 1841 . First Vice-President, May 5, 1841, to May 17, 1843. 


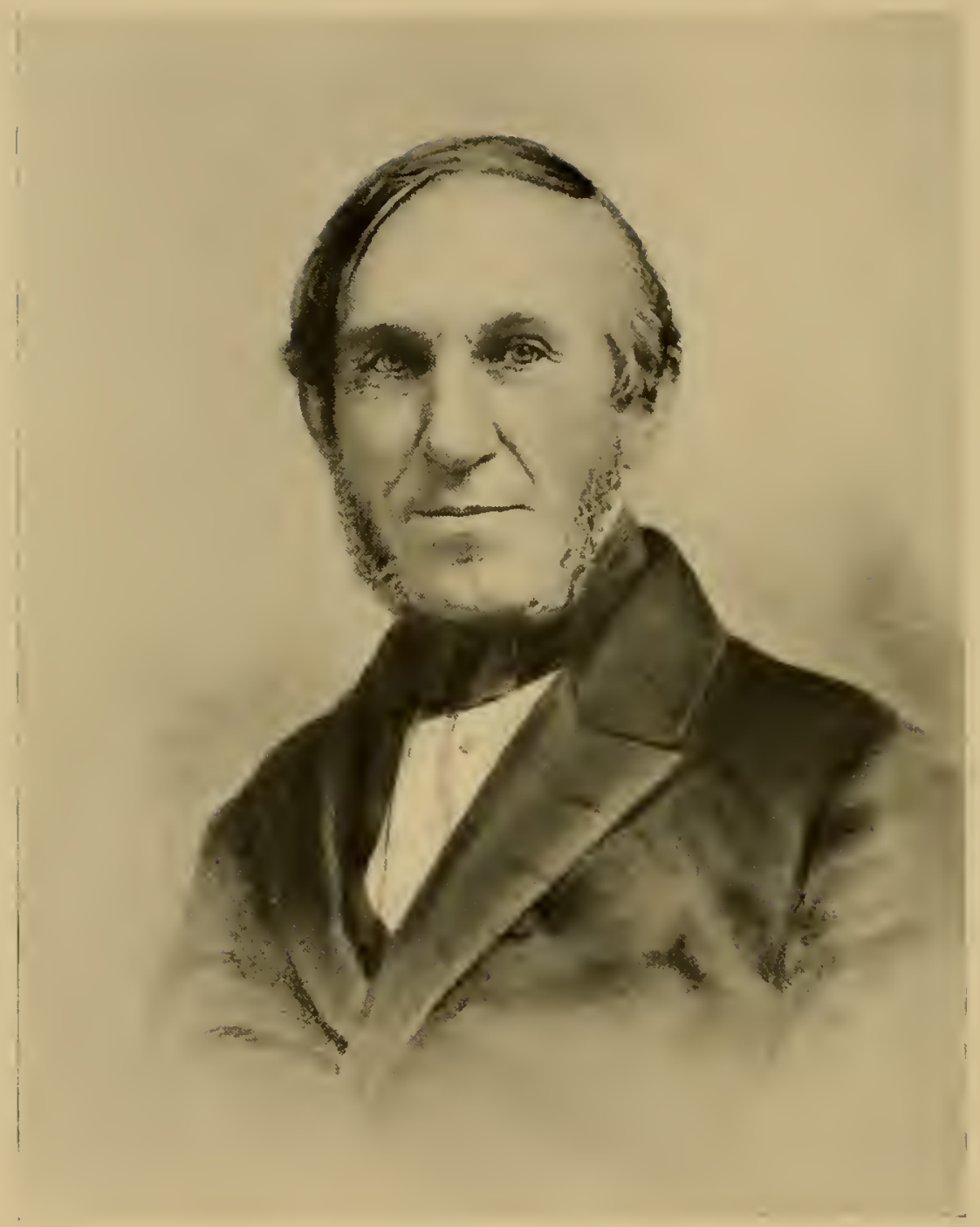

$$
\begin{aligned}
& \text { ALIGLISTLIS A. GOLLLD } \\
& \text { I } 805 \text {-1 } 866 \text {. Original Member. }
\end{aligned}
$$

Curator, May 4, 1831, to May 2, 183s. Recording Secretary, May 2, 1838 , to May 15, 1839. Curator of Conchology, May 5, 1841, to May 17, 1843. Second Vice-President, May 2, 1860, to September 15, 1866. 
President'Thomas 'I. Bouré: "'The country was involved in a war which. by rapidly wasting its resources, threatened alike its national prosperity and its progress in Art, Science, and Literature. 'There was sadness in the hearts of men and an undefined evil pervading their minds, tending to concentrateall thought upon the movements of armies and the tidings of conflict. 'Thank God there was an unfaltering faith in the final success of the struggle for the Nation's integrity which kept alive hope and encouraged exertion for all movements promising future good to the community. 'Thus it was that in the midst of a dreadful civil war, the Society was enabled, through the untiring derotions of its own members and by the exertions, contributions, and bequests of many friends, to erect the fine structure that now adorns the city, and to place therein the great collections of Natural History that now minister to the delight and the instruction of multitudes." Nor were the life and development of the Society maintained at the expense of the duty which its members owed to their conntry in the field, for ninety-eight of them served in the war, a large proportion of the Society's membership.

It is impossible within the compass at our disposal to indulge in a retrospect complete enough to outline the many activities of our members, so we must content ourselves with giving the names of those who took the most active part in the proceedings of the Society in the critical times between the thirtieth and fortieth Milestones (1860-70). Doctors: Jeffries Wyman, C. 'T. Jackson, B. Joy Jeffries, James C. White, Charles P'ickering, Augustus A. Gould, Hemy Bryant, Bert G. Wilder, C. F. Winslow, William Stimpson, 'Thomas M. Brewer, Herman A. Hazen, J. 13. S. Jackson, A lexinder Agassiz. Professors: I couis Agassiz, IVilliam B. Rogers, H. .J. Clarke. Mcssrs. S. H. Scudder, F. W. Putnam, A. E. Verrill, Horace Mann, C. 'T. Sprague, Charles Stodder, William 'T. B3righam, R. C. Green- 
leaf, N. S. Shaler, B. P.Mann, F. G.Sanborn, E. Bicknell, and C. S. Minot.

In this list the student of Natural History will recognize names which have earned immortal fame in the annals of their State and Country.

$$
\begin{gathered}
\text { The Thirty-Nintl Milestone } \\
\text { I } 869
\end{gathered}
$$

$\mathrm{O}$ $\mathrm{N}$ September 14, in this year, the centennial amniversary of the birth of Alexander von Humboldt was held under the auspices of our Society. 'The Rev. Robert C. Waterston, D.D., on this occasion presented the portrait of Humboldt, painted by the Boston artist, Mr. M. Wight, who wrote the following letter to the donor of the portrait which now hangs in our Museum. Humboldt declared the portrait by Wight to be the best ever painted of himself.

Rer. R. C. Waterston:

Dean Sin, You have requested me to give some account of Humboldt, whose portrait I had the honor to paint. I beg leave briefly to state that in 185.2 I saw him in Berlin. INe was at that time eighty-three years of age. 'The first interview was on the occasion of his sitting for the portrait in February of that year. I found him a man rather below the medium stature, dressed with the utmost simplicity, in black. His step was moderate, but firm and decided, with his head a little inclined forward. In conversation, his face woukl glow with enthusiasm and his small clear eyes sparkle with animation. He was apparently very tenacious of his time. There were five sittings. I found him always prompt to the minute. Knowing that he had received several decorations from crowned heads, I asked him if he wished me to represent any of them in his por- 


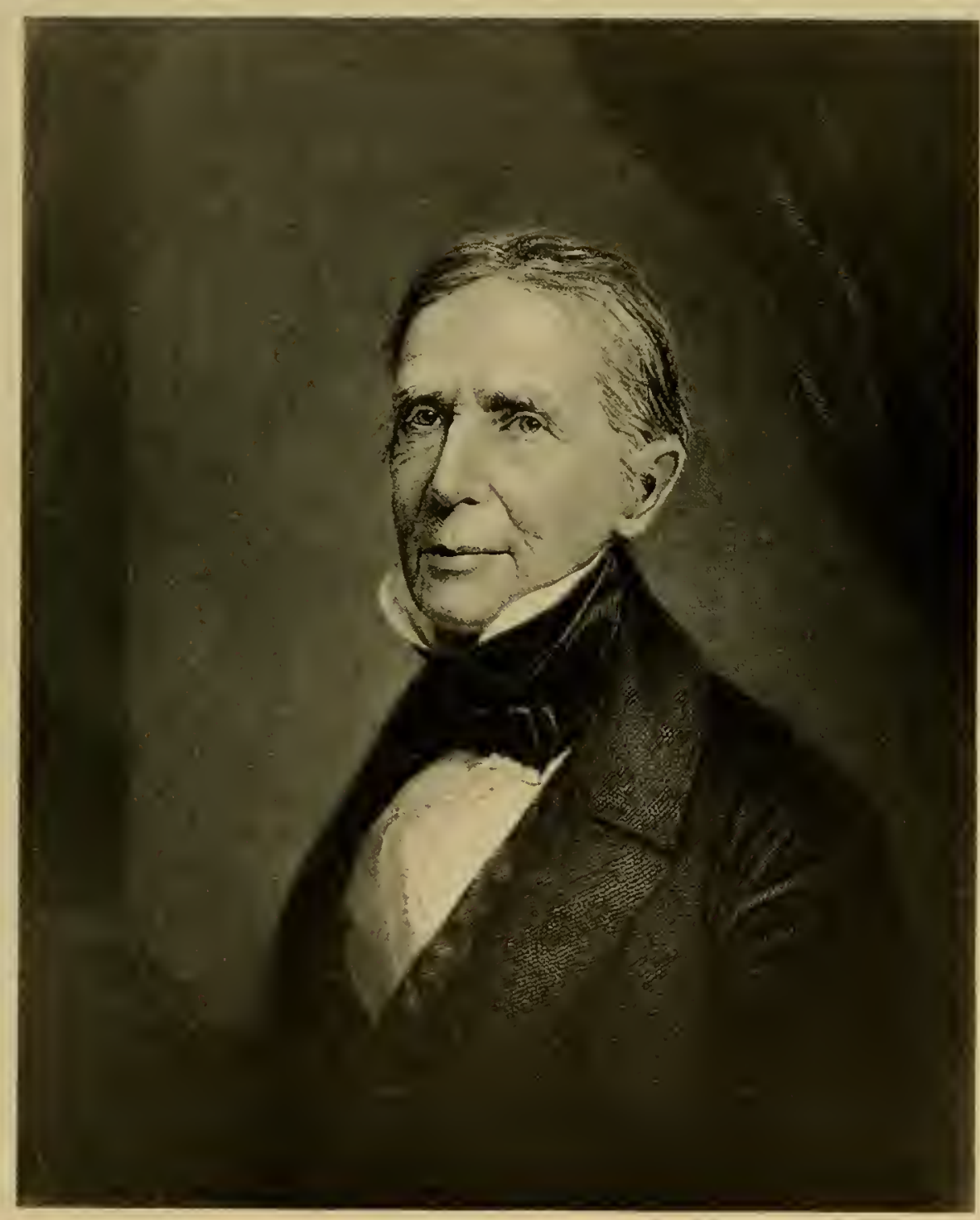

JOHN COLLINS WARREN

I 778-1 856. Member 1834 .

President, May 5, 184T, to May $\downarrow, 1856$. 


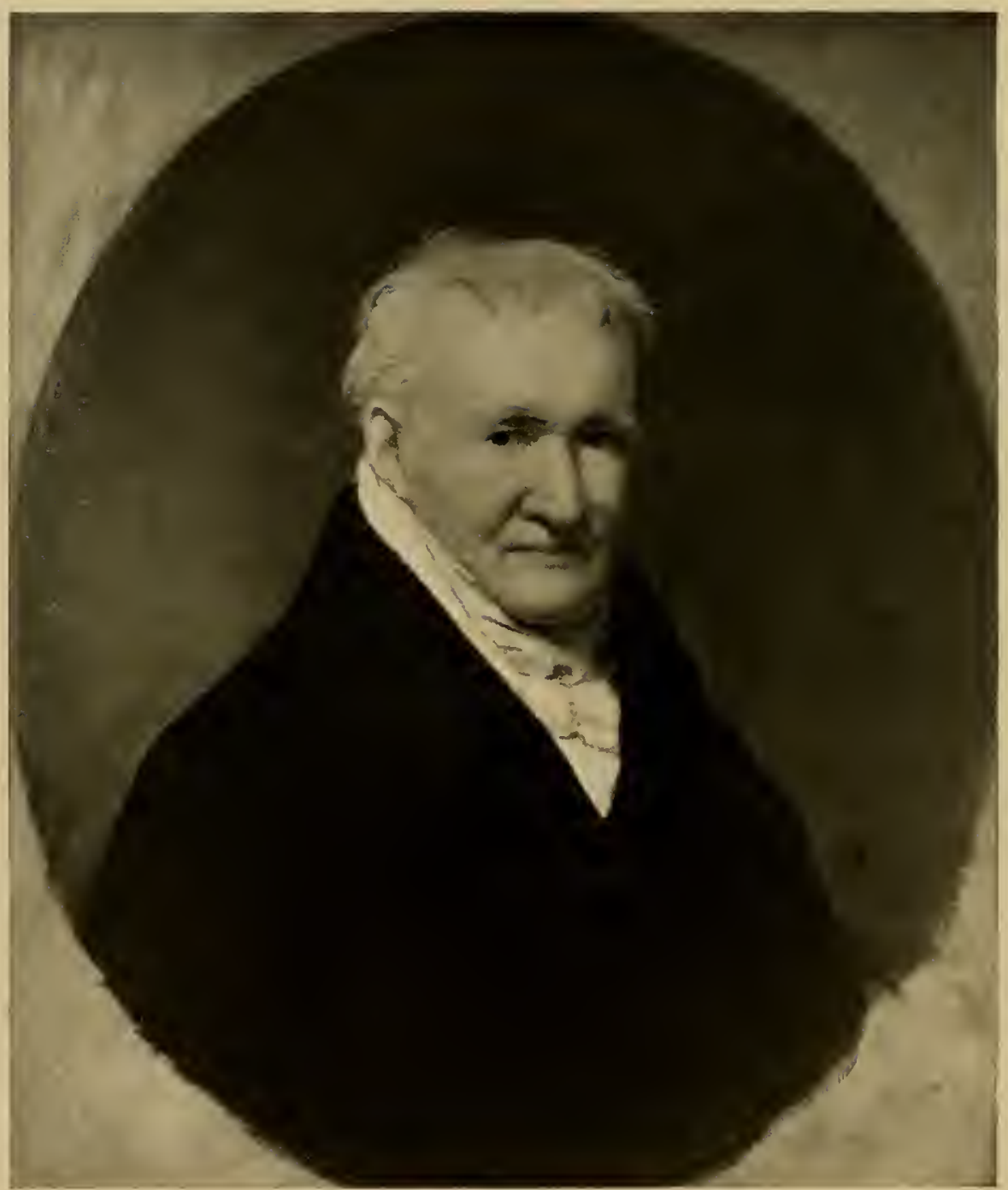

\section{ALEXANDER VON HLIMBOLDT Aged 8;.}

Painted in Berlin by Mr. Wight in 1852. Presented to the Society by the Rev. Robert C. Waterston on the occasion of Humboldt Centennial on September 14, 1869 , held under the auspices of the Society. 
trait; he replied that he preferred it should be painted without any ornament whatever. He spoke of his pleasant visit to the United States, and took great interest in the afficirs of our country. At his house he showed me several pencil drawings of mountain scenery made by his own hand, very carefully done, and as carefully preserved.

My studio was in Französisch Strasse. His residence was in another part of the city, where he lived in a plain, substantial building, in a quiet and unostentatious manner. As soon as it became known that a portrait was being painted of Humboldt, a lively interest was manifested upon the subject, particularly among the American residents and students, an unusually large number of whom were at that season in Berlin. On each sitting he was accompanied by a valet, who attended him upstairs, and either left or remained in the hall until the allotted time for sitting within expired, when Humboldt immediately arose, and, politely taking his leave, departed. An interesting conversation was kept up at intervals during the sittings, at two or three of which the Hon. 'Theo. S. Fay, our Chargé d'Affares in Prussia, was present. When the portrait of the great naturalist was completed, many persons, citizens and strangers, as well as artists, and among the latter Cornelius, famed for his magnificent cartoons and frescos in church, palace, and cathedral, and Rauch, the immortal sculptor and anthor of the statue of Frederick the Great, together with other personal friends of Humboldt, came to sce it. Before the portrait was sent to America it was exhibited to the citizens in the grand hall of the Art Union of Berlin.

It affords me great pleasure to place in your hands the original portrait of Humboldt, to be used on this occasion of the centennial celebration of his birth. 'The copy of the portrait which you desired 
is now completed. I consider it as faithful a likeness, in every respect, as the original.

Very respectfully, your obedient servant,

Boston, Sept. S, 1869

II. WIGHT

In his famous oration at the Humboldt centennial celebration Louis Agassiz made this eloquent plea for Higher Education:

"We have all a great task to perform. It should be our effort, as far as it lies in our power, to raise the standard of culture of our people as Humboldt has elevated that of the world. May the community at large feel with equal keemness the importance of each step now taken for the expansion in every direction of all the means of the highest culture. The physieal suffering of humunity, the rants of the poor, the creing of the lungry and nulied, appeal to the symputhy of everyone who has a human heart. But there are necessitics which only the destitute student linow's; there is a hunger and thirst which only the highest charity eren understund and reliever, and on this solemn oceasion let me say that coery dollar given for Higher Edueation, in athatever special department of hnowledge, is likely to hase a greater influence upon the future character of our nation then we'n the thousands and hundreds of thousands and millions which have abready been spent and ice are sluily spending to raise the many to national e'ase and comfort."

Agassiz spoke as one who had himself undergone " the necessities which only the destitute student knows, the hunger and thirst which only the highest charity can understand and relieve" for as a young man of twenty-four years of age in Paris he had come to the end of his resources and was faced with the abandonment of the Science which he loved so well. Humboldt happened to hear of the plight which meant such poignant grief to A gassiz, and with charac- 


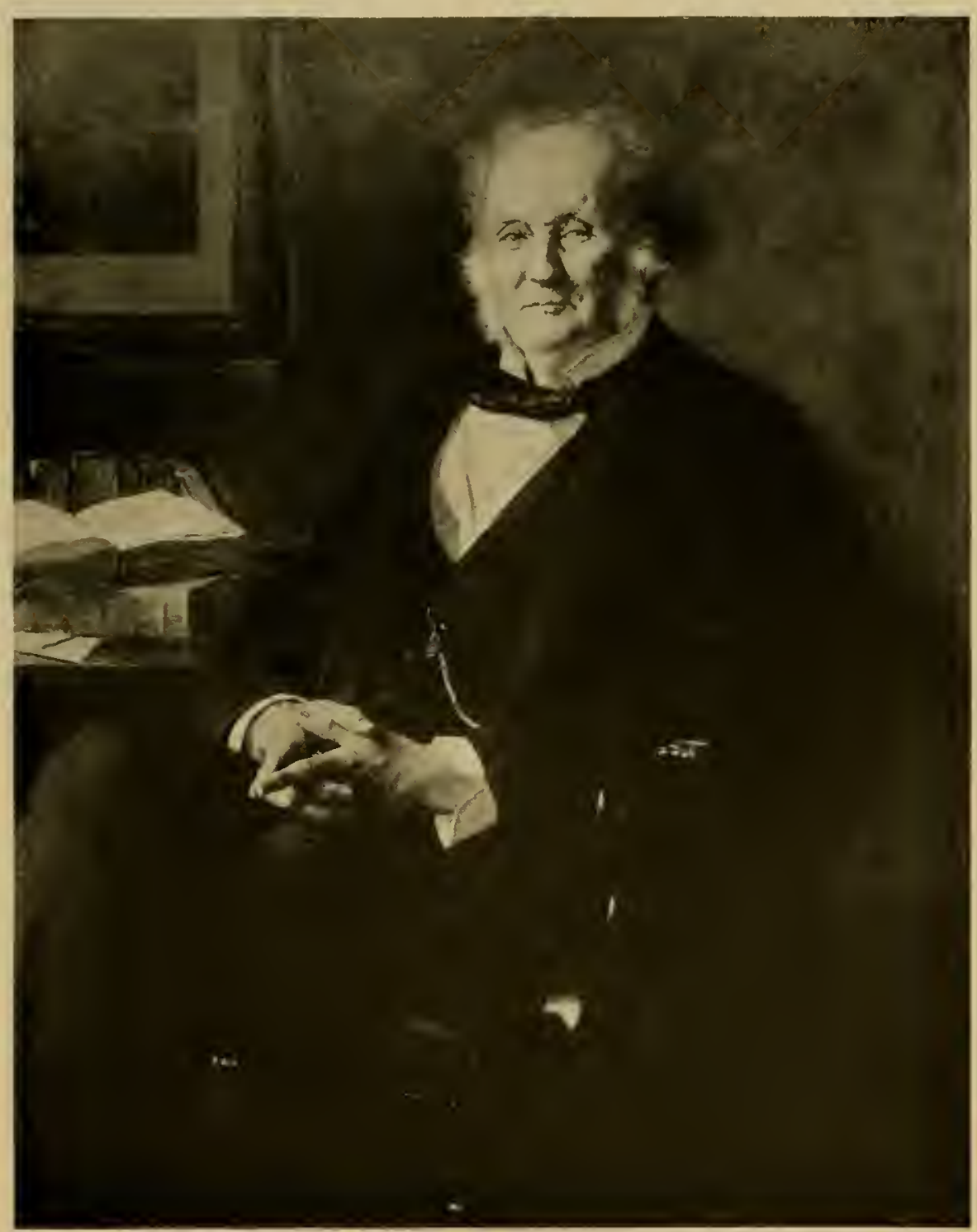

D. HUIMPHREYS STORER

I $804-189$ г. Original Member.

Recording Secretary, September 21, 1830, to Nay 4, 1836 . Curator of Ichthyology and Herpetology, May 2, 1838, to May 17, 1843. Second Vice-President, May 17, 1843, to May 2, 1860. 
teristic generosity came to the rescue with a loan but for which the genius of Agassiz might never have shone on America or the world.

Poems were written by Oliver Wendell Holmes and Julia Ward Howe for this occasion of which we give the concluding stanzas.

Bring the white blossoms of the waning year,

Heap with full hands the peaceful conqueror's shrine

Whose bloodless triumphs cost no sufferer's tear!

Hero of knowledge be our tribute thine!

$$
\text { [o. w. H. ] }
$$

Seer of the inward vein and outward blossom,

Master of laws that nurture and control,

He learns, dark Mother, in thy hidden bosom,

The unimagined secret of the soul.

$$
\text { [J. พ. н.] }
$$

\section{The Forty-First Milestone$$
I \& 7 I
$$

$\mathrm{T}$ this year an important change of policy was inaugurated, on which the present policy of the Society is based. Hitherto, the Society had established a museum, had founded a library; had held meetings, given lectures, and published scientific papers. What they did was in accordance with the best thought prevailing anywhere in such institutions as that of the Society. Members had, however, begun to feel the need for a more scientific and definite orientation of their activities - a compass-bearing by which they could steer their bark on the sea of human knowledge. It was decided to rearrange the contents of the Museum in a scientific method by which the exhibits would rest on a logical background of relationship. Within this reorganization was the decision to form separate New England collections in each department. So we owe 


\section{Milestones}

the origin of our present policy of concentration solely on New Englind's natural phenomena to the foresight and common sense of those who, sixty years ago, realized how they could best serve the people of New England and took practical steps to this end.

\section{The Forty-Third Milestone I $\$ 73$}

TOWARDS the end of this year our Society sustained a griev1 ous loss through the death of Louis Agassiz, who had been an honorary member of the Society from 1837 until his death. President 'Thomas ' $T$. Bouvé, speaking at a meeting of the Society on January 7,187 , shortly after his death, said of him:

"Since we last met, an event has occurred that has brought deep sorrow to our hearts, and indeed moves with grief those of the whole community; for whilst in the death of the great Naturalist we lave lost a distingnished honorary member, a pioneer in the paths we love to tread, one whose name deservedly ranks high among the most illustrious of those who have explored the world of matter and of life, the great body of the community has lost one whom it has long and justly regarded as preëminently the great teacher in Science, the man of all men, who inspired the love of knowledge and who was never weary in his efforts to impart the best he knew to every seeking soul.

"Truly, all alike, learned or unlearned, high in attainments and position, or humble seekers of truth, may well weep the loss of him whose presence alone was to everybody an inspiration.

"To those of us who have been in iny degree sharers in his labors or companions in literary or scientific circles, his loss is irreparable.

"The advent of Agassiz is to be considered a most important 
event in the Natural History of the country. The example of his character, his disinterestedness, hisconsecration to Science, his readiness to oblige even the lumblest and most modest, his superiority to self-interest, his sincerity and absence of all pretensions, his enthusiasm in all that is noble-all these recommended not only him but the Science he professed. Never was a life more richly filled with study, work, thought; and all was consecrated not to the benefit of himself but to the promotion of science for the good of his fellow-creatures."

\section{How Louis Agassiz came to America}

\section{[LETTER FROM SIR CHARIES LYELL TO MR. GEORGE TICKNOR]}

London, IIarch 1, 184.5

My desR Mr. Tickxor.

I am trying to negotiate with $\mathrm{Mr}$. Lowell for a course of lectures from the celebrated ornitlologist and Swiss naturalist and writer on glaciers for $18+5-46$, but perhaps all are filled up. Charles Buonaparte, Prince of Canino, has offered to take him to the United States. as lie visits it with his son this ycar. I am sure Mr. Iowell will do it if he can, as I have answered for his English being passable. You will be much pleased with Agassiz, and his risit will be most useful as it always is to us when he comes here. The British Association has thrice roted him sums of moncy to describe our fossils.*

Lines addressed to Agassiz on his fiftieth birthday by Longfellow:

It was fifty years ago

In the pleasant month of May,

In the beautiful Pays de Vaud,

A child in its cradle lạ.

* Life of Sir Charles Lyell, vol. ii, p. 91 . 


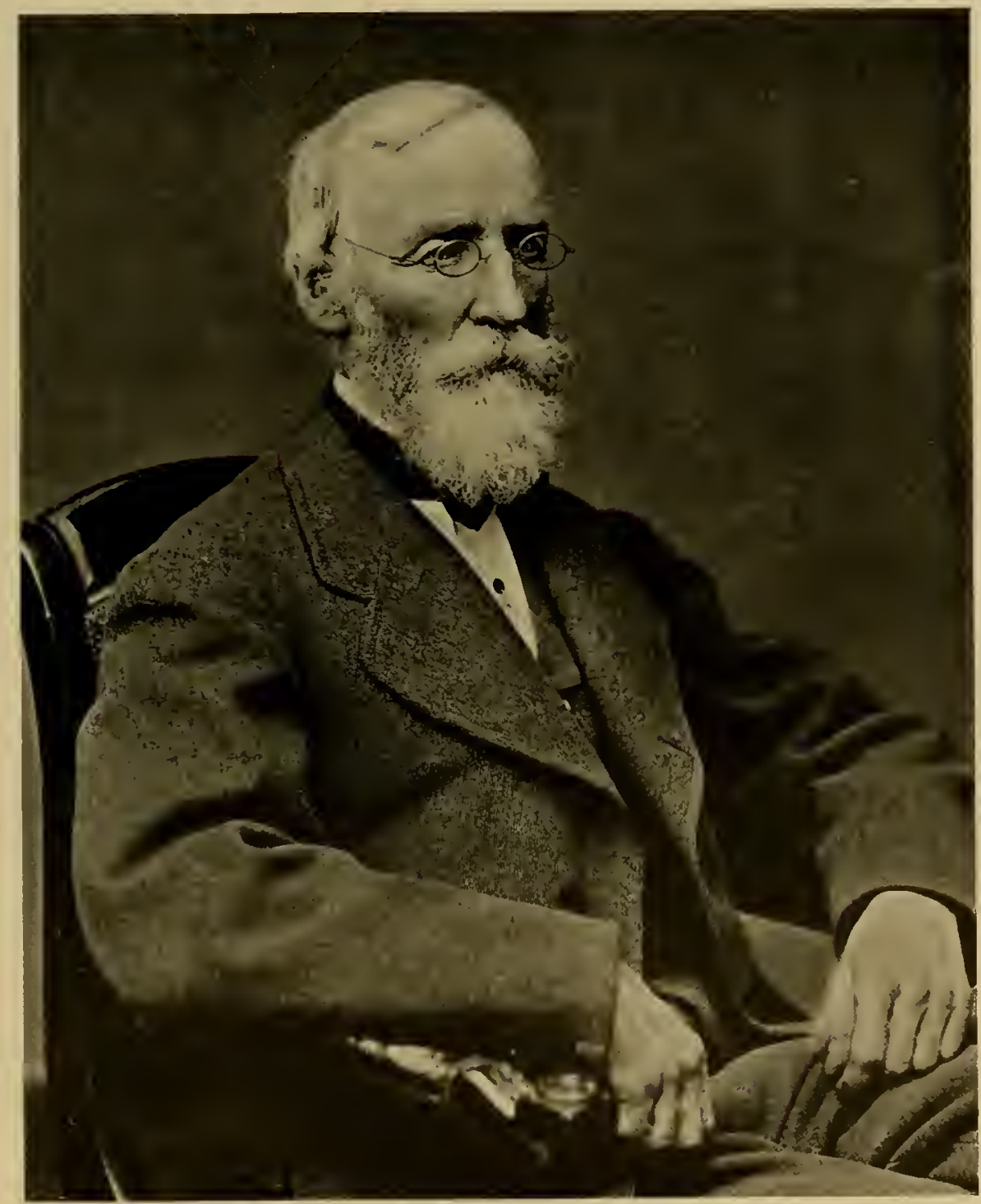

JEFFRIES WYMAN

I $814-1874$. Member 1837 .

President, June 18,1856, to May 4,1870 . Curator of Nammals, May 1, 1839, to May 6, 1848. Curator of Reptiles and Fishes, May 17,1843, to May 3, 1848. Curator of Reptiles, Nay 3, 1848, to May 7, 1851. Curator of Comparative Anatomy and Mammals, June $\tau, 1851$, to May 6 , is5\%. During his presidency, the present building was erected. 


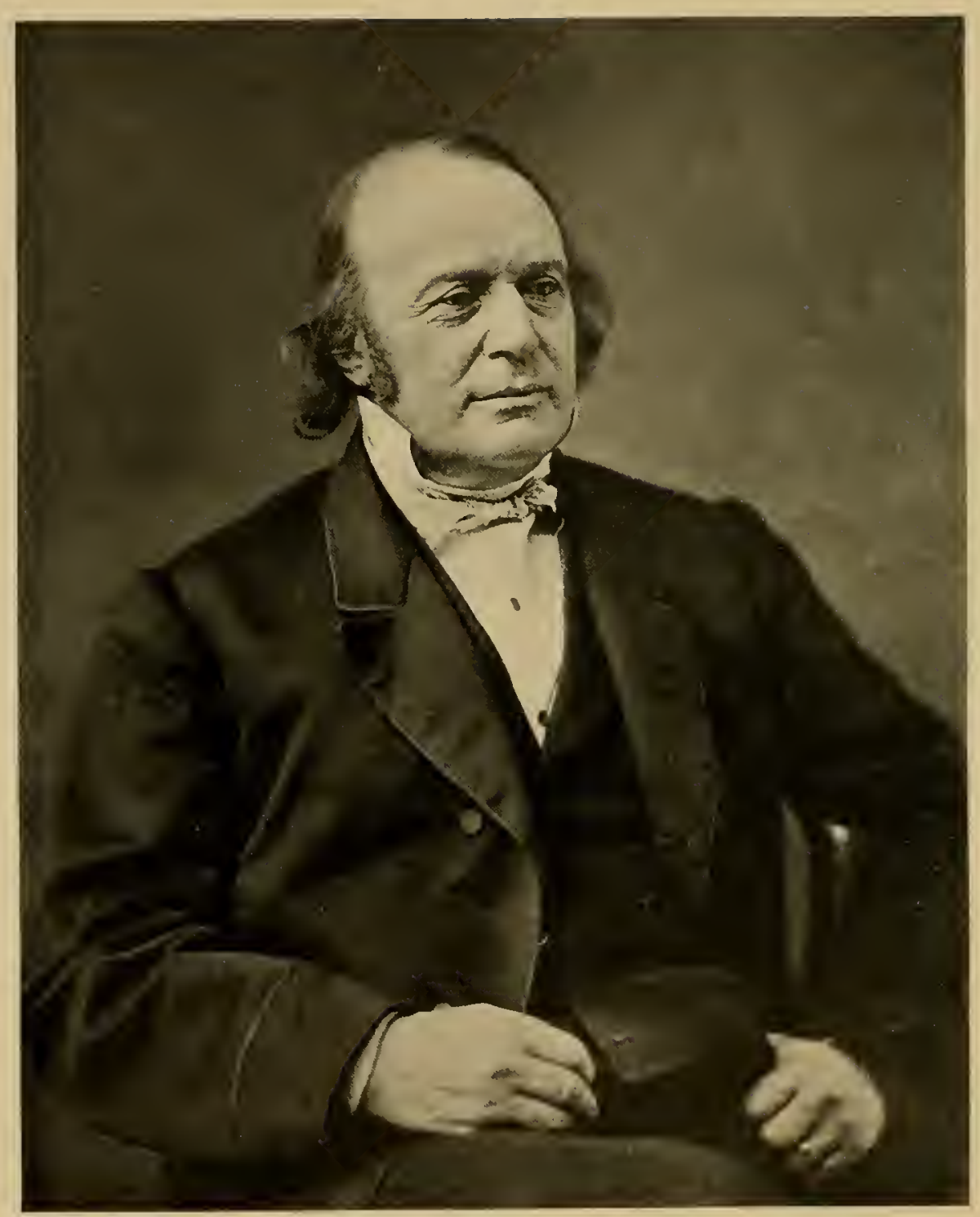

\section{LOLIIS AGASSIZ

$$
\text { I } 807-1873 \text {. }
$$

Elected Honorary Member of the B.S. N. H., August 16, 1837, while still in Neuchâtel, Switzerland. 
And Nature, the old nurse, took

'I'he child upon her' knee,

Saying: "Here is a story-book

'Thy Father has written for thee.

"Come, wander with me," she said,

"Into regions yet untrod

And read what is still unread

In the manuscripts of God."

And he wandered away and away

With Nature, the dear old nurse,

Who sang to him night and day

The rhymes of the universe.

And whenever the way seemed long,

Or his heart began to fail,

She would sing a more wonderful song,

Or tell a more marvellous tale.

\section{The Fiftieth Milestone I $\&$ So}

THE Semi-Centennial Celebration on April 28, 1880, was an 1 important erent, the record of which is a fascinating story worthy of the indomitable men upon whose sacrifices the Society was built, stone upon stone. They have earned imperishable fame though this consideration had no place in the single-minded devotion with which they served the cause of Science and Education. No true American can read the history of the first fifty years of our Society without a virid realization of the sterling character, great ability, and self-sacrificing spirit to which we owe so much. The story of the Boston Society of Natural History is the story of Massa- 
chusetts in miniature, for the Society attracted the allegiance of her noblest sons who represented the one true aristocracy - the aristocracy of spirit.

Among the distinguished company present on this occasion were His Excellency, Governor John D. Long; * President Charles W. Eliot of Harvard University; Professor Asa Gray, the illustrious botanist; Doctor Alexander Agassiz, Director of the Museum of Comparative Zoölogy; Count Louis François de Pourtalés; Dr. Samuel Eliot, Superintendent of the Public Schools; Miss Lucretia Crocker, Supervisor of the Public Schools; Dr. D. Humphreys Storer; Judge G. W. Warren; Hon. Josiah Quincy; Professor E. S. Morse; Colonel'Theodore Lyman; Dr.J. C. White; Professor F. IV. Putnam; Rev. Robert C. Waterston; Mr..Justin Winsor, Librarian at Harvard Unirersity; and Mr. Jolnn Cummings. The President of the Society, Mr. 'Thomas 'T. Bouvé, was in the chair.

The addresses of such speakers as Governor Iong, President Charles IV. Eliot, Doctor Alexander Agassiz, Rev. Robert C. Waterston, and Dr. Samuel Eliot were worthy of the occasion. In order to do them justice it is expedient to reproduce their own words whose value would be lost in compression or paraphrase.

ADIRESS HY IIS RXCEILENCY, GOVERNOR LONG

I remember that the seeds of your noble institution, like those of so many of the best fruits of New England, were sown not altogether by the scientists nor by any onc profession. but by common men who lifted up their eyes above the ordinary toil of life, and who for themselves and their fellow-men reached out to higher levels of knowledge and usefulness. I remember, too, that your first great cndowment came from a merchant-type of the unbroken

* Governor John D. Long was Secretary of the Navy under President MIcKinley, 1897-1902. 


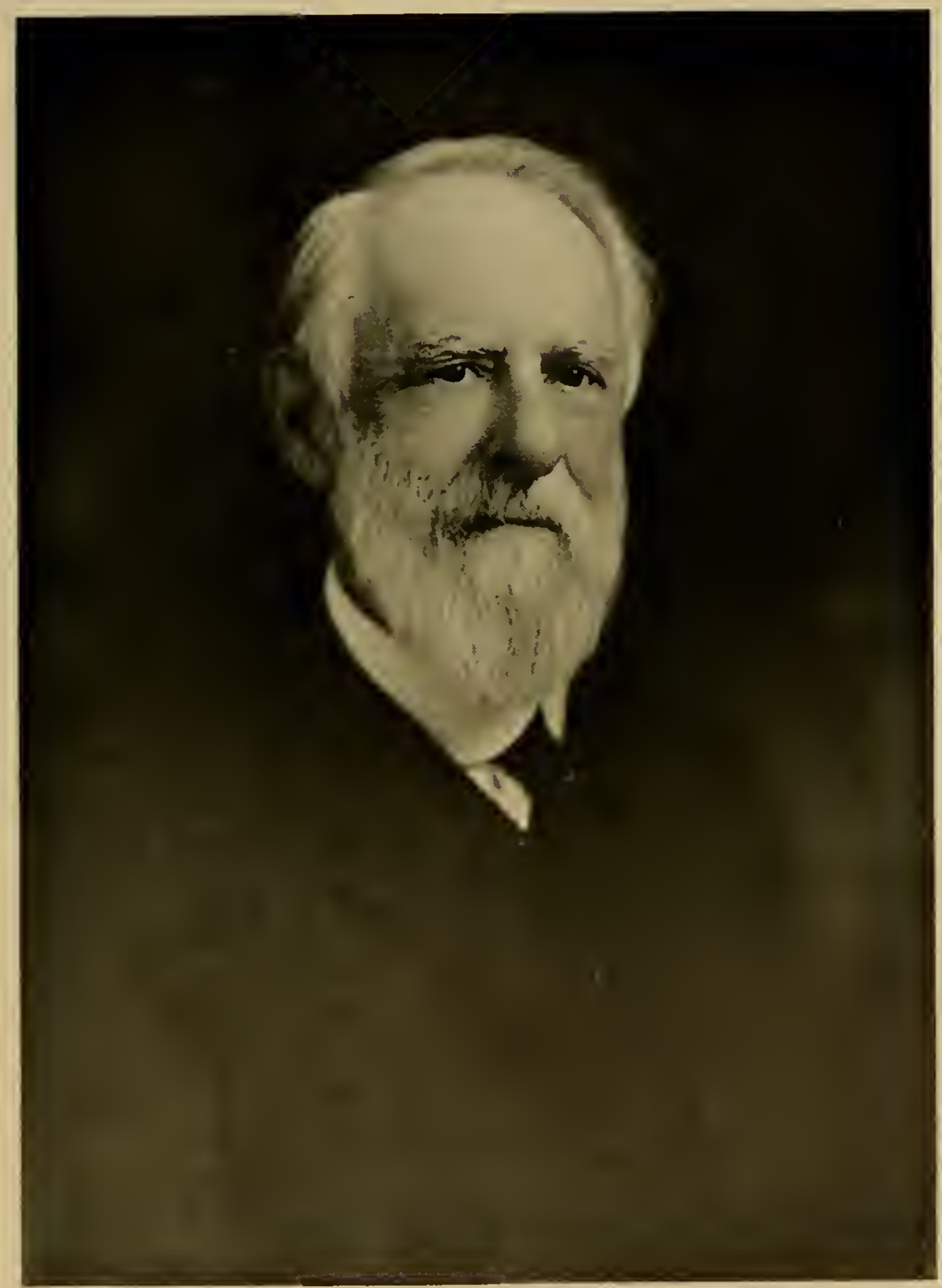

FREDERICK WT. PUTNAM

$$
\text { 1839-1915. Mcmber I } 856 \text {. }
$$

President, May 4, 1887, to May 6, 1891. Second Vice-President, May 5, 1880 , to May 4, 1887. Curator of Ichthyology, May 4, 1859 , to May 4, 1870. 


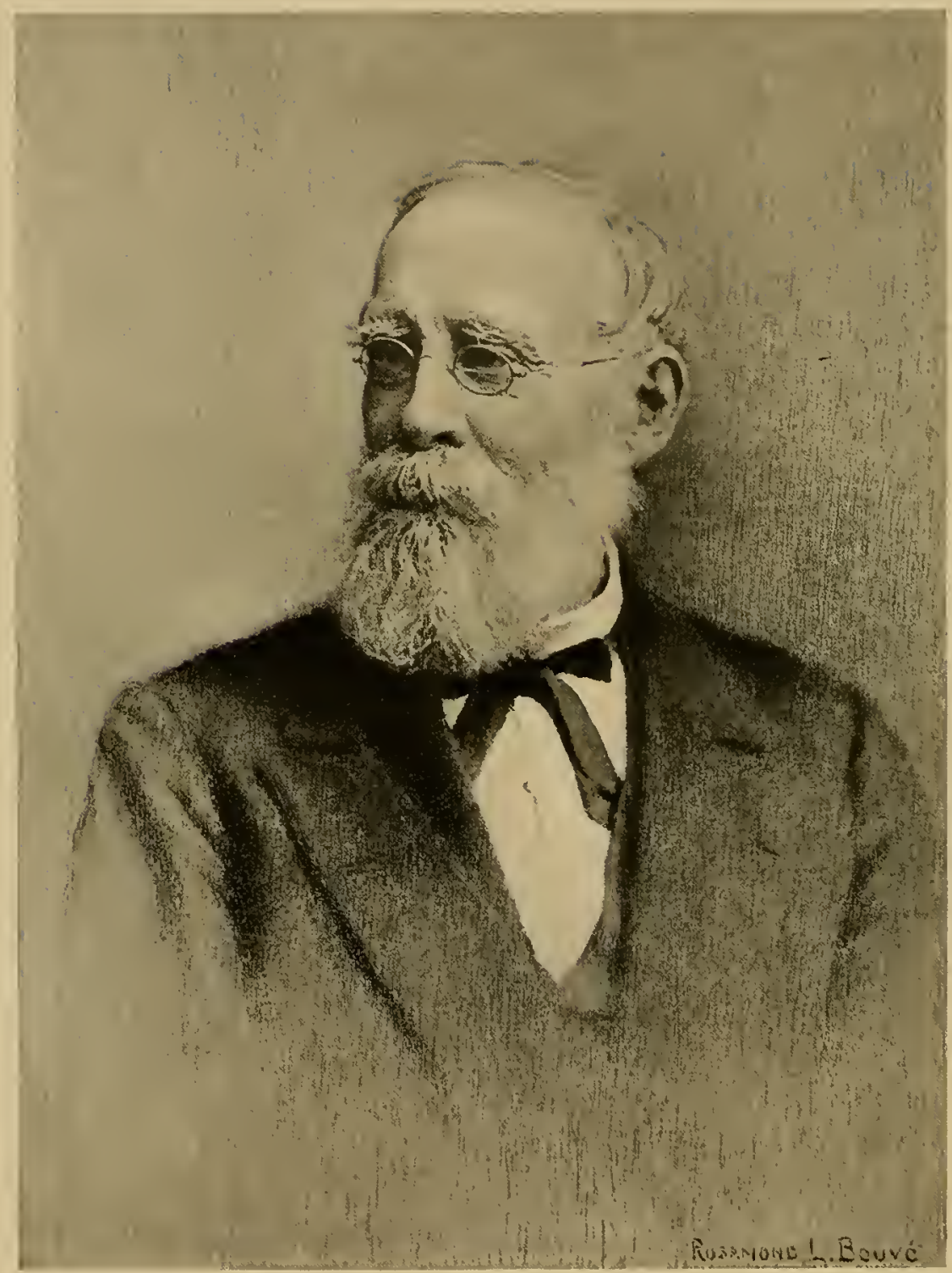

THOMAS T. BOUVÉ

I $815-1896$. Member i 834 .

President, June 15, 1870 , to May 5, 18so. Curator of Geology, May 4, 1842, to May 4, 1863. Curator of Geology and Paleontology, May 4, 1863 , to January 2, 1867. Curator of Paleontology, January 2, 1867 , to May 1, 1867. Second Vice-President, November 21,1866 , to June, 1870. 
line of the peerless merchants of Boston-who was little known among scientific scholars, yet contributed from the accumulations of his thrift to a higher culture than his own. And I remember, more than all, that the Commonwealth, which from the days of her founders until now never yet has failed the cause of education among her children, had from the first been the steadfast friend of this Society, giving it incorporation, aiding it in its early years with a modest but saving annual subsidy, and, in 1861, making to it the magnificent donation of land on which its foundations now rest secure-a donation that came not only with the good will and the Godspeed of the Commonwealth, but with all the sympathy and inspiration of the soul of Governor Andrew, who, next to his derotion to human rights and hate of human wrongs, cherished the love of that enlarging learning which he knew is from the meanness of wrong to the nobility of right, the slow but sure highway.

And so as one of the many citizens of Massachusetts, and also as one in official station representing her, I am emboldened to unite my roice in the acclaim that hails this fiftieth amiversary of your existence. Mcmory and imagination - those exquisite poets of the human mind - memory that looks tenderly back over the past, and imagination that idealizes and yet in all its mounting knows that it fails to picture or command the future - are making this occasion not the mere boast of fifty years' success, but a tribute to what man has done, and a stimulus to what man yet a thousand times more shall do in behalf of the happiness, the delight, the knowledge, the ennobling of his fellow-men, unlocking from every nook and comer of the eirth, and displaying in every form and motion of life, the beneficence of God. 
'This Society has two distinct objects: (1) the promotion of Natural History by stimulating and aiding ad vanced study and original research, and ( $\boldsymbol{2}$ ) the enlightenment of the common people concerning animate and inanimate nature. What I have to say touches each of these two objects.

It would carry us into a discussion too solemn for this occasion to attempt to state the primary reasons which should induce men to study Nature devotedly, although no tangible benefits could ever flow from that study; for I have never been able to find any better answer to the question - what is the chief end of studying $\mathrm{Na}$ turc? - than the answer which the Westminster Catechism gives to the question, what is the chief end of man? - namely, "l'lo glorify God, and to enjoy him forever."

I shall ask your attention to a proposition which contains only a secondary, though sufficient, reason for fostering the study of Natural History - to the proposition that the human race has more and greater benefits to expect from the successful cultivation of the sciences which deal with living things than from all the other sciences put together. I by no means forget what mechanics and physics have brought to pass within a hundred years. 'They have already reduced the carth to one-tenth of its former size, as regards the carriage of persons and goods, and for the transmission of thonght, will, and fact, they bid fair to make the whole surface of the globe as one room. They have made it easy, on the one hand, to concentrate population in dense masses, and on the other to reach new soils and shores, and to distribute to all countries the peculiar productions of each. These wonderful achievements of mechanies and physics, aided by chemistry, produce indirect effects upon the wellbeing of man, some good effects and some bad, with a probable pre- 
ponderance of good; but their direct influence upon human character and happiness is not large. 'The reduction in size of our earth, our country, or our town, which railways, telegraphs, and telephones have brought about is in itself no satisfaction. Rapid locomotion is not an object in itself. Does the average man get any more happiness out of his little span than he did one hundred years ago? or does he have a longer span? And if he does, have the inventions of the past century in mechanics and physics been a direct cause of the improvement? 'The answers to these questions are not ready and clear. WVe hesitate to gire an affirmative reply. 'The fact is that mechanics and physics deal only indirectly with human miserynamely, climatic influences, not understood, and, therefore, not to be guarded against, violent and umpredictable extremes of heat or cold, wetness or dryness, ravages of noxious plants and animals, diseases both of men and of useful animals, and untimely deaths. All these evils belong to the domain of Natural History, and for ultimate deliverance from them we must look to the student of Natural Science...

Can we not clearly foresee that by the patient, thorough, cumulative study of Natural History in all its branches, men will gradually arrive at a knowledge of plants and animals, and of the favorable and unfarorable conditions of life for all plants and animals, which will give them control over many evils which they now find wholly mysterious and irresistible? ...

Antiquity had its great students of nature, but they lacked the means of diffusing, preserving, and accumulating their discoveries. The past four centuries have had abundant means of recording and transmitting from one generation to another all the scientific truth which they became possessed of. It is in this steady, patient and orderly accumulation of facts concerning living things that the hope 
$36 \quad$ Boston Society of Natural History

of wimning for man new powers over the gravest natural evils really lies. This Society has a part in making that pregnant record.

There is another aspect of your work which seems to me very important. You propose to maintain for the public an exhibition of all forms of vegetable and animal life in their wondrous and endless variety. Hither people may come and see their fellow-beings in the widest and trnest sense. Moralists tell us that the best development of an individual man is not to be reached throngh introspection, self-reference, and an overweening anxiety about his own salvation. 'They say to every man, "look out and not in." 'The same exhortation might well be addressed to the human race. Nankind needs to look ont, and not in; to realize that it is but one, though a noble one, among countless races and tribes of creatures which inhabit or have inhabited this atom of earth, and that its welfare is not the sole end of creation or the one absorbing interest of the Creator. A few years ago all men believed that the whole boundless universe centered upon man. That delusion has lost its hold, except perhaps within the well-protected domain of dogmatic theology. But there are still many people who cling to the kindred conceit that this earth, at least, was made for man. It is a belief which will not survive much acquaintance with the vast solitndes of the earth which teem with other life than man's - the everglades, the jungles, the mountains, and seas. It is a belief which a thoughtful man or child will be apt to qualify or resign, as he studiously examines such a collection of Natural History as this Society strives to maintain.

ADDRESS OF DOCTOR AIEXANDER AGASSI\%

The scientific man should be without nationality, ready to welcome progress from any quarter. Science is bound neither by country 


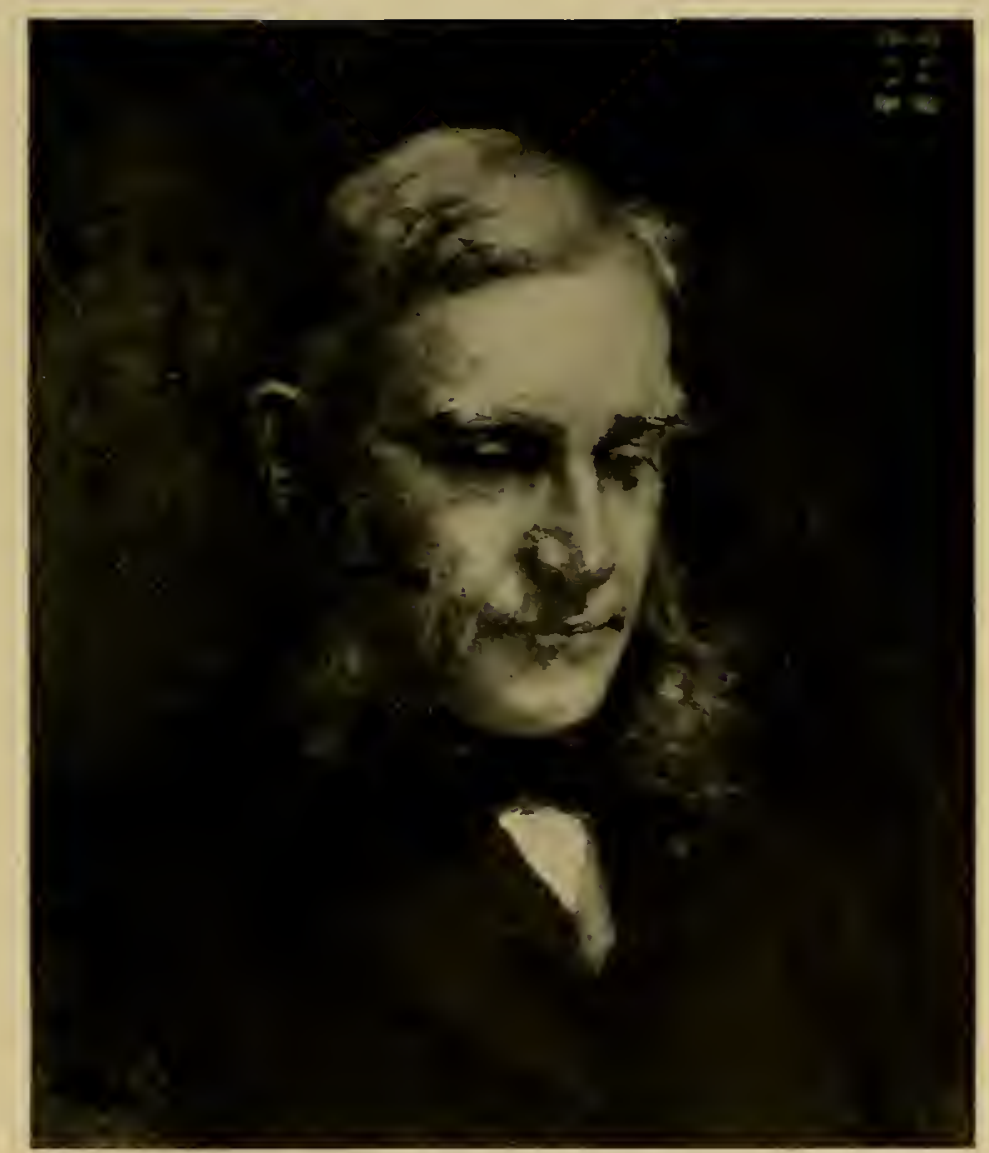

SAMUEL H. SCUDDER

1837-191 1. Member I855.

President, May 5, 18s0, to May '4, 1887. Curator of Entomology, March 16, 1859, to May 4, 1870 . Recording Secretary, May 7, 1862, to May 4, 1870. Librarian, May 4, 186t, to May 4, 1870. Custodian, May 4, 1864, to May 4, 1870. 
nor creed in its relation to new information. An important publication, a new line of research, a brilliant hypothesis, should appeal to us, not because it is American, German, French, or English, nor because it is on the wimning side in the questions of the day. It is, of course, natural that a country comparatively young in scientific culture should turn to older institutions for its standards, should be constantly tempted to compare its orn learned societies and their doings with those of more ancient date and established influence. But, while measuring our progress by theirs with honorable emulation, let us not make the mistake of also measuring our scientific men by a reflected light only, making our own recognition of them wait upon that from the other side of the water. Every nation should be proud of its great men, and may be excused for overrating them, but it should also add to an excusable national vanity, an independence capable of recognizing, appreciating, and sympathizing with the men who are raising the intellectual standard of their country to that of the older ones. The pioneers of Science in this country were neither remote imitators nor simply commentators; they have not only laid the foundations of Natural Science in this country, but they have extended its boundaries on many fields. Nor should we assume that they had need of a kind word of recognition from the other institutions or individuals. Let me not, however, be understood, for a moment, as disparaging the intelligent criticism of Press or colleagues at home or abroad. I only wish to distinguish between that and the notoriety so easily gained by constant appeals to the public either in person or through scientific quacks.

Since, however, the true investigator rarely has either the time or the disposition to become the expounder of his own work, it is not always possible for the public to draw the line between those 


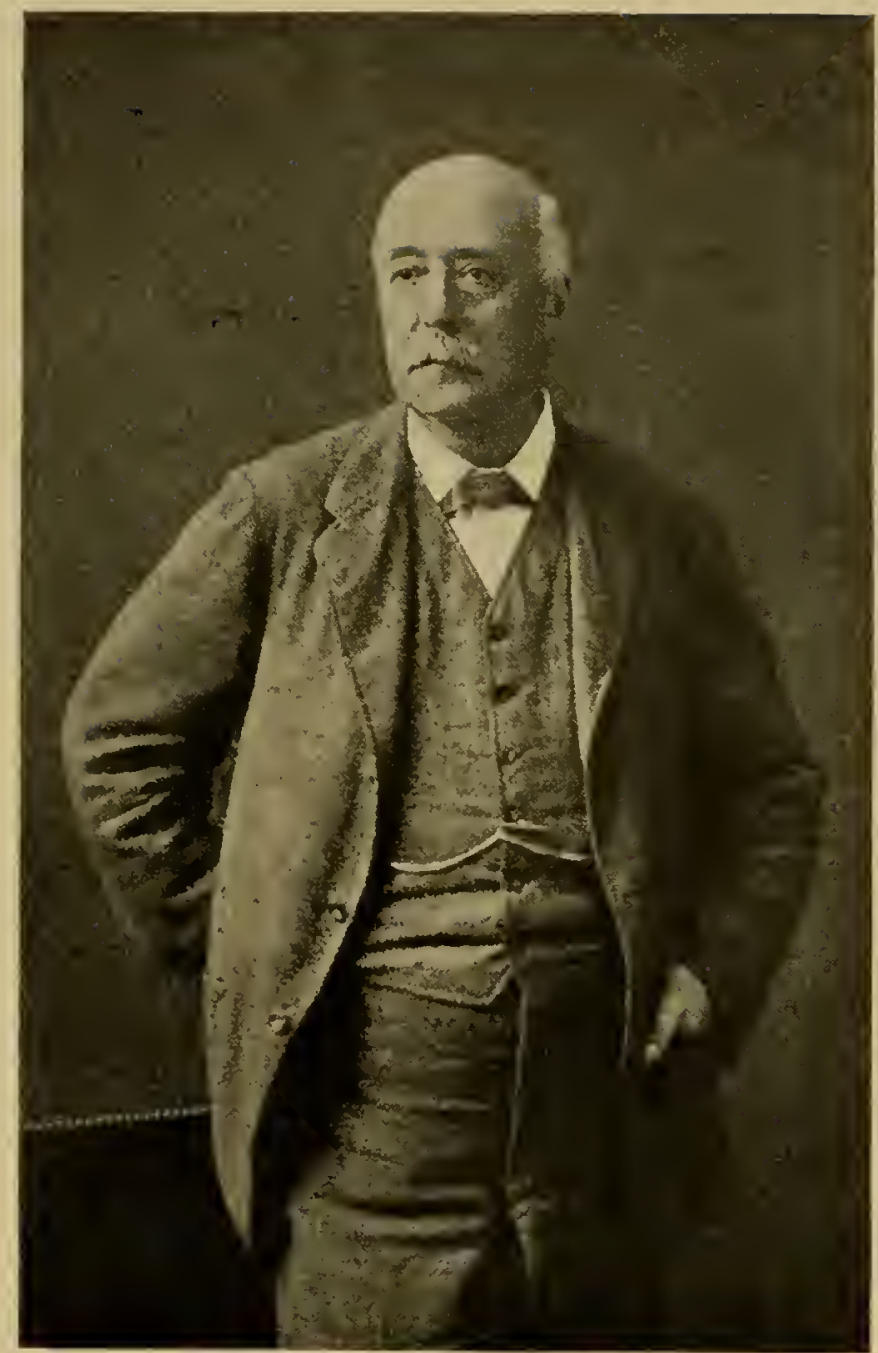

ALEXANDER AGASSIZ

Curator of Entomology, 185S-1859. Curator of Crustaceans, 1870. 


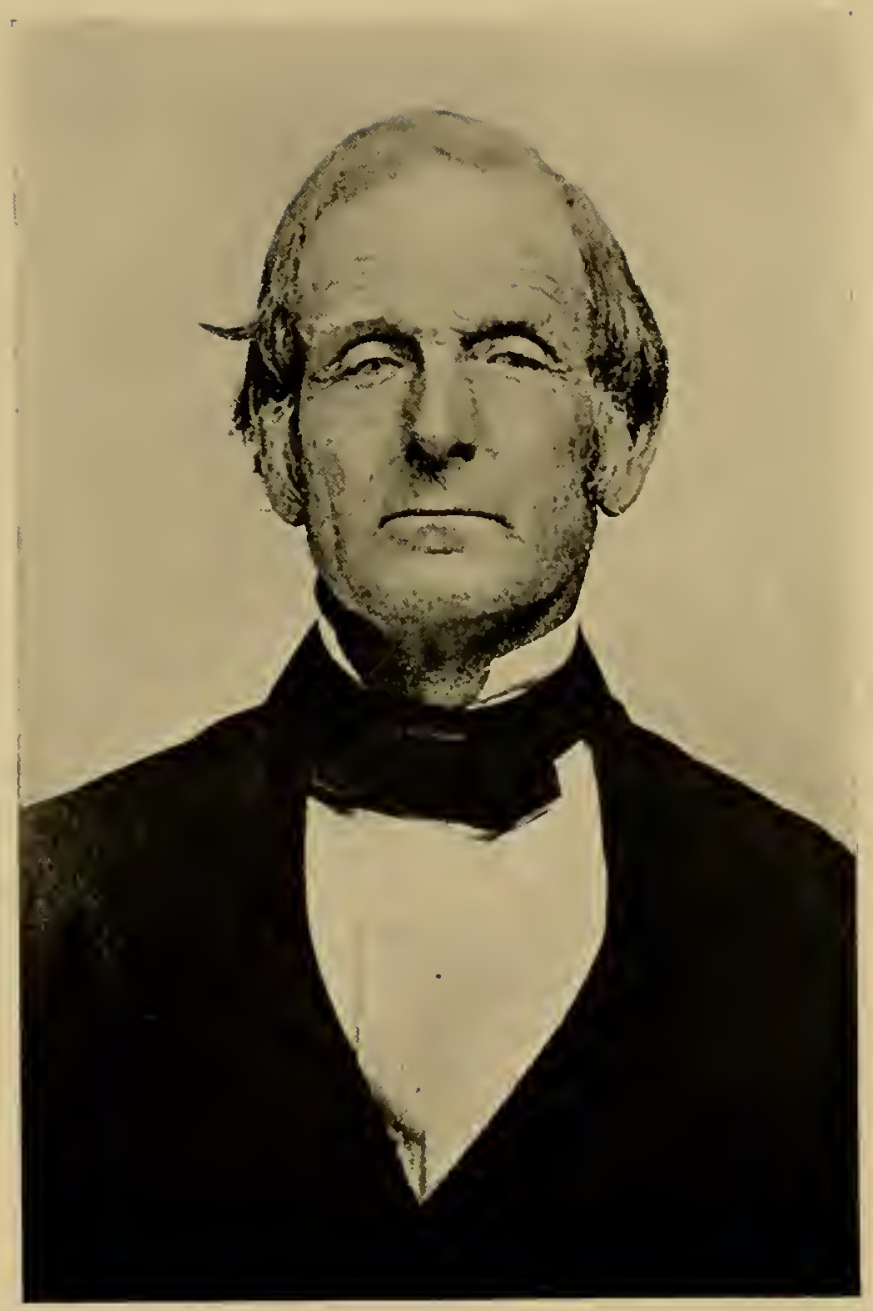

NATHANIEL E. ATWOOD

Member 1847.

Curator of Ichthyology, December 17, 1856, to May 5, 1858. Carried on the first fish hatchery in Massachusetts. 


\section{Milestones}

who speak from their own knowledge and the scientific litterateur. who forages in any field where booty is to be gained. We have met to-day to honor the pioneers of Science in this country by a grateful recognition of what has been accomplished from the small beginnings of fifty years ago. Taking up some of the more prominent names of the early days of the Natural History Society. we must reward the highest place to men like Wyman, Harris, Bigelow, Gould, Storer, and Binney, whose investigations have paved the way for their successors of the present day. They were men of no ordinary stamp. 'They were men who in any country wonld have been recognized as leaders in Science, and whose fame will live when many of us are forgotten.

\section{ADDRESS OF THE REV. ROBER'T C. WATERSTON}

'Teachers and pupils may often be seen together, thoughtfully pursuing their investigations from hall to hall, some with artistic skill making drawings, others taking notes, and many more lost in astonishment and filled with admiration and delight.

But, added to this, regular classes have been formed to which systematic instruction has been given. The study of Natural History having been definitely introduced into the public schools, a new zeal has been awakened among the teachers. With some teachers, additional knowledge is a necessity, while with all it is evidently a pleasure. The different branches are pursned under the guidance of able professors in connection with this Society. What is known as the "T'eacher's School of Science" has acquired positive importance. Professor Hyatt. the Custodian, has been unceasing in his efforts, and has been gratified at the extraordinary success which has followed his labors. This special work has been going on for the last ten years, but never with such marked results as during 
the past year. The number of applicants for admission to these lectures las been four times larger than in any previous period. Orer six hundred persons recorded their names as students, while the average attendance on each pleasaut day was five hundred. 'There have been distributed among these students more than one hundred thousand specimens. Yes, during the present year there has actually been given away - not one thonsand, or ten thousand, or fifty thonsand specimens, but (though one can bardly credit it): one hundred thousand specimens, all of which may be studied by the teachers at their homes or used for illustration in their schools.

We talk of the wonders; yet here is a still more felicitous method of communication; six lundred intelligent teachers, going forth from this place to convey the knowledge thus gained to thirty thousand young people, full of life and eager to lean. 'Thus has this Society become more emphatically than ever before, an educational power in the community.

Dr. Samuel Eliot, Superintendent of the Boston Public Schools, in his address said:

"I think, as I stand here, of the scenes that I have looked upon in this and the adjoining building where the teachers in our public schools hare gone at the invitation of this Society and through individual genius and the teachings of the friends of this Society have received lessons which they in their turn have given to their children. And when I think of all that this involves of nearness to Nature. which forms so truc an essential of education, and which, without such help as this Society has given would be to-day little more than a name anong our teachers and pupils, I feel that I have the right, in behalf of the public schools of Boston and of the whole community, to thank the Society of Natural History for the help which they have given us." 


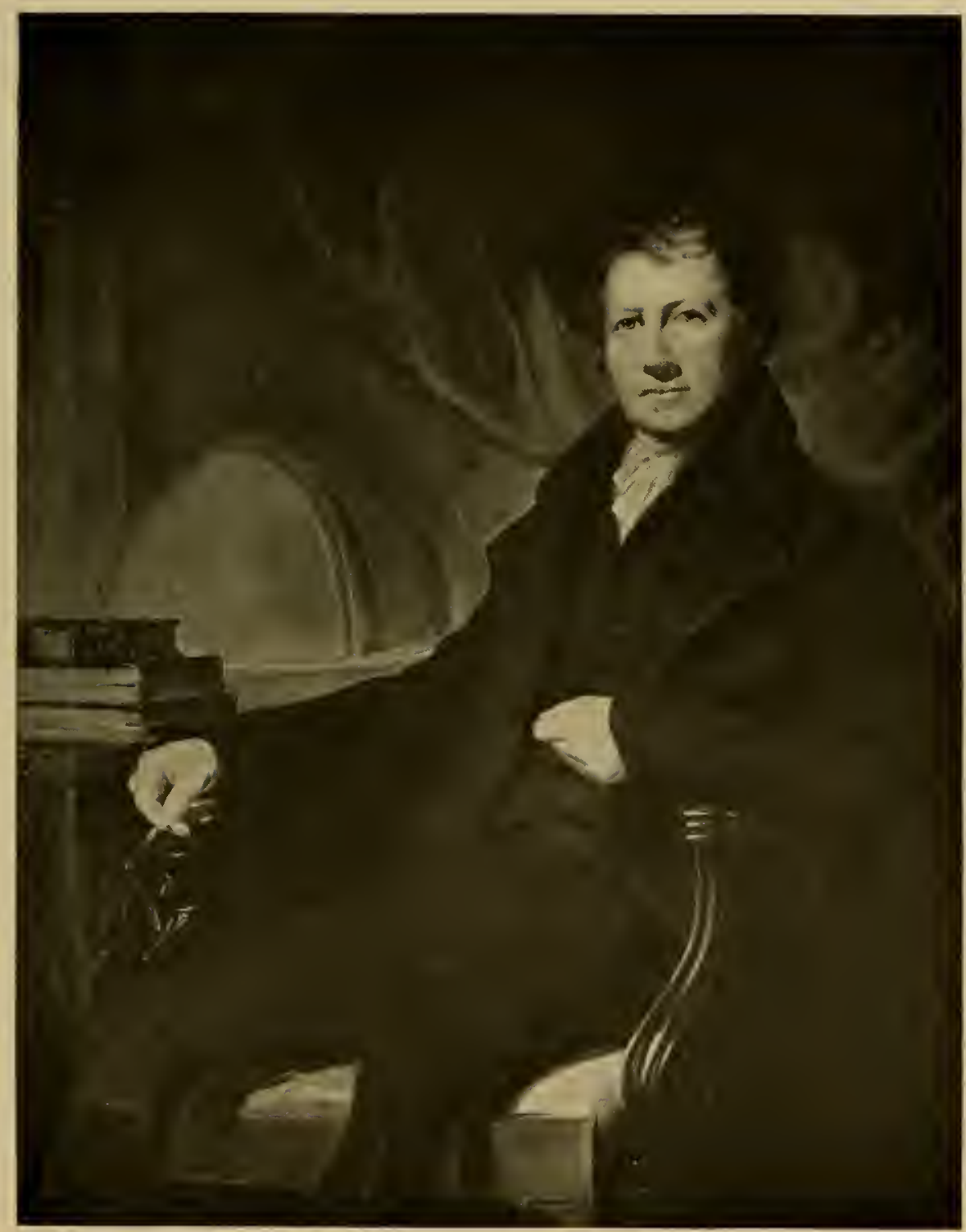

THOMAS M. BREWER

I 8 I 4-1880. Member I 835 .

Cabinet Keeper, May 3, 1837, to May 2, 1838. Curator of Ornithology, May 2, 1838, to May 6, 1840. Curator of Oölogy, July 2, 1851, to May 4, 1870.

This portrait was painted by John Woodhouse Audubon, son of John James Audubon, and given to the Society by Miss M. E. Andubon. 


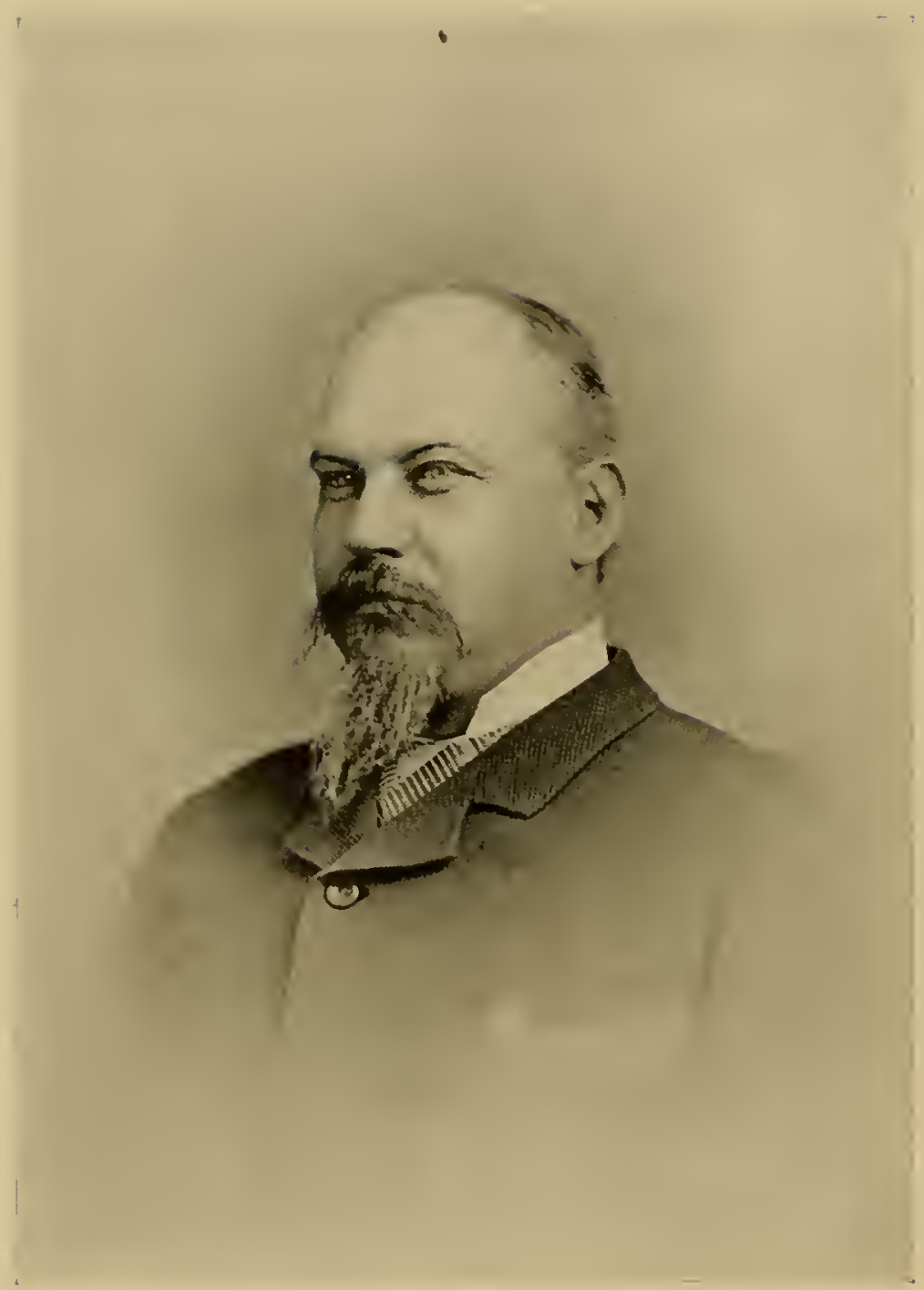

ALPHELIS HYATT

1838-1902. Member I 860 .

Curator of Conchology, October 21, 1863, to May 1, 1867. Curator of Paleontology, May 1, 1867, to May 4, 1870. Custodian, May 4, 1870, to January 15,1902 (died in oftice). Organized the 'Teachers' School of Science. 
At the end of the first fifty years the hopes of the Society for the future were thus outlined by 'Thomas ' $\mathrm{I}$. Bouvé:

"Of its aspirations for the future, they are such as all will commend who recognize that progress is a duty, riz.: that it may be able to meet the increasing call from a growing community for instruction in Natural History for such as cannot arail themselves of the advantages afforded otherwise, by an expansion of its laboratory and other facilities; that it may, before a long period has elapsed, be able to add an aquarial garden to its collection, both for the study of the habits of a portion of the animal kingdom and as an additional attraction to visitors of the Museum; that as these desires cannot have full fruition without more extensive accommodations, the day may not be far distant when it shall possess the ability to enlarge the Museum building so as to serve best its designs and purposes; and that it may also be able to publish the increasing researches of its members with the illustrations they require, which it is now by no means able to do, many memoirs being diverted to other channels of publication which would naturally be offered to the Society were it able to do nore than at present."

\section{The Fifty-Second Milestone I $\delta \& 2$}

7 OLLOWING our plan of allowing those who played a great - part in building up our Society to speak for themselves, we will now introduce Professor Alpheus Hyatt who occupied the responsible post of Curator of our Museum. His views were expressed in annual reports. They reflect indirectly the lack of funds which prevented the Museum from keeping its place as one of the leading scientific institutions in the world, the rank claimed for it and con- 
ceded to it in its early days, a rank to which it devolves upon us to restore our historic Museum. He says:

"The experience of the past ten years $(\mathbf{1 8 7 2 - 8 2})$ has demonstrated the futility of any attempt to inpress the community with an aldequate sense of the public importance of the Museum without the aid of illustrations sufficiently perfect in themselves to show exactly what we intend to do. These must not only exhibit the general interest of the information which is to be made arailable, but also prove, that a Museum is capable of becoming an instrument of public culture unequalled in the power of awakening intelligent appreciation of the usefulness of its work in the minds of those visiting its collections.

"It is possible to so arrange, and subsequently conduct, a Museum that it will be much more effectual in this way than any Art Gallery, or Library, as Nature herself is greater and more instructive than any imitations of her erer set in frames or between the corers of books."

In a later report Professor Hyatt said:

- Last year (1894), special attention was called to the scientific investigations of Professor Crosby in the Department of Geology. and to the need of keeping up and providing for such a class of work, if we desired to do our part in the history of Science in New England. We are essentially a local society and ought to strive to do a large share of the local work of investigation. For the past year this Society has paid one of its salaries to this investigator and permitted him to count his purely scientific work in the field and in this building as a return for the money paid him. The amount expended has been very small and the returns, as seen by this report, large. So far as I linor, hocerer, this Socicty is the first institution 


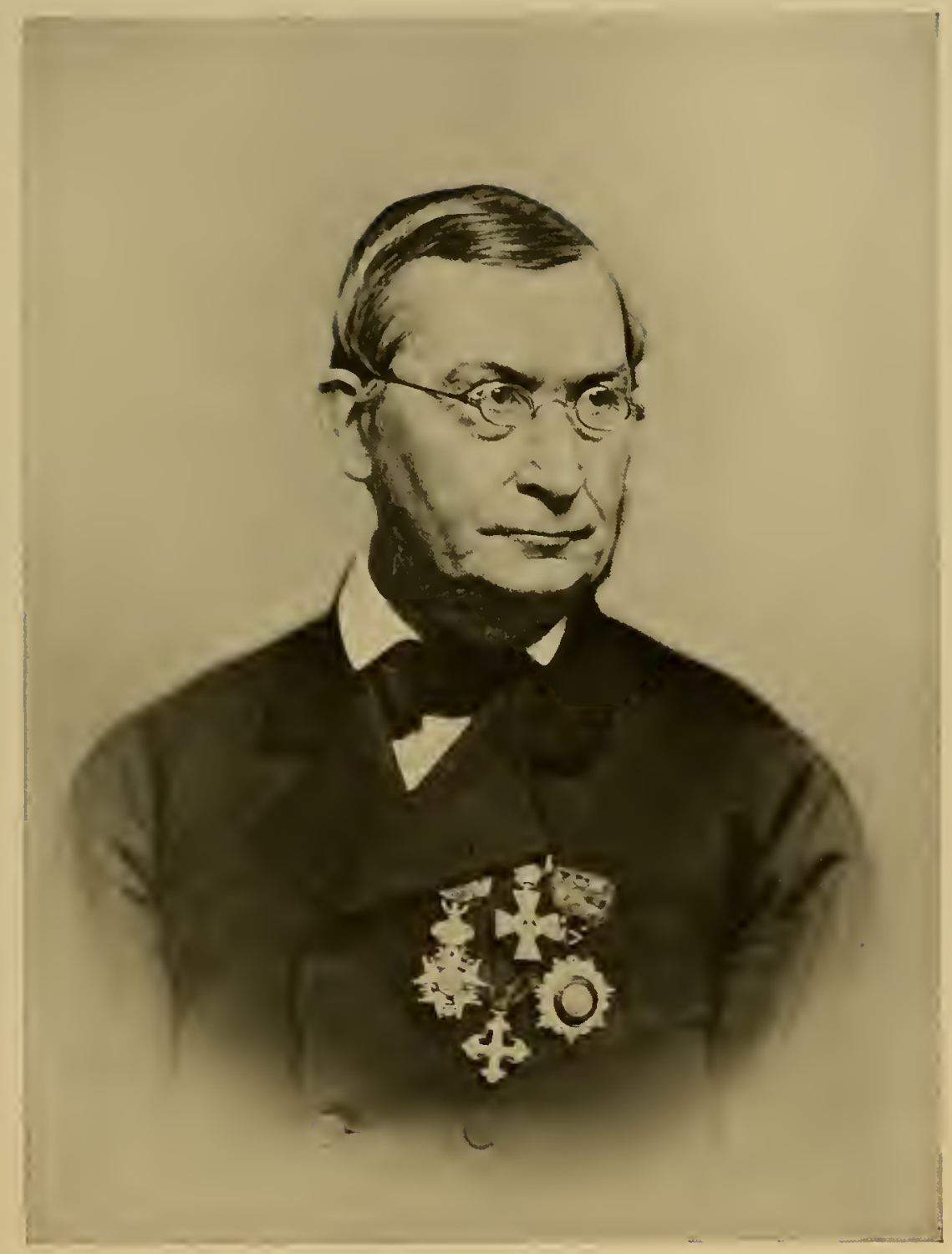

CHARLES T. JACKSON

I $805^{-1} 880$. Member I 832 .

Curator, May 1, 1833, to May 2, 1838. Curator of Mineralogy and Geology, May 2,1838 , to May 5, 1841. Second Vice-President, May 5, 1 841, to May 17, 18+3. First Vice-President, May 17, 1843, to May 6, 1874 . 


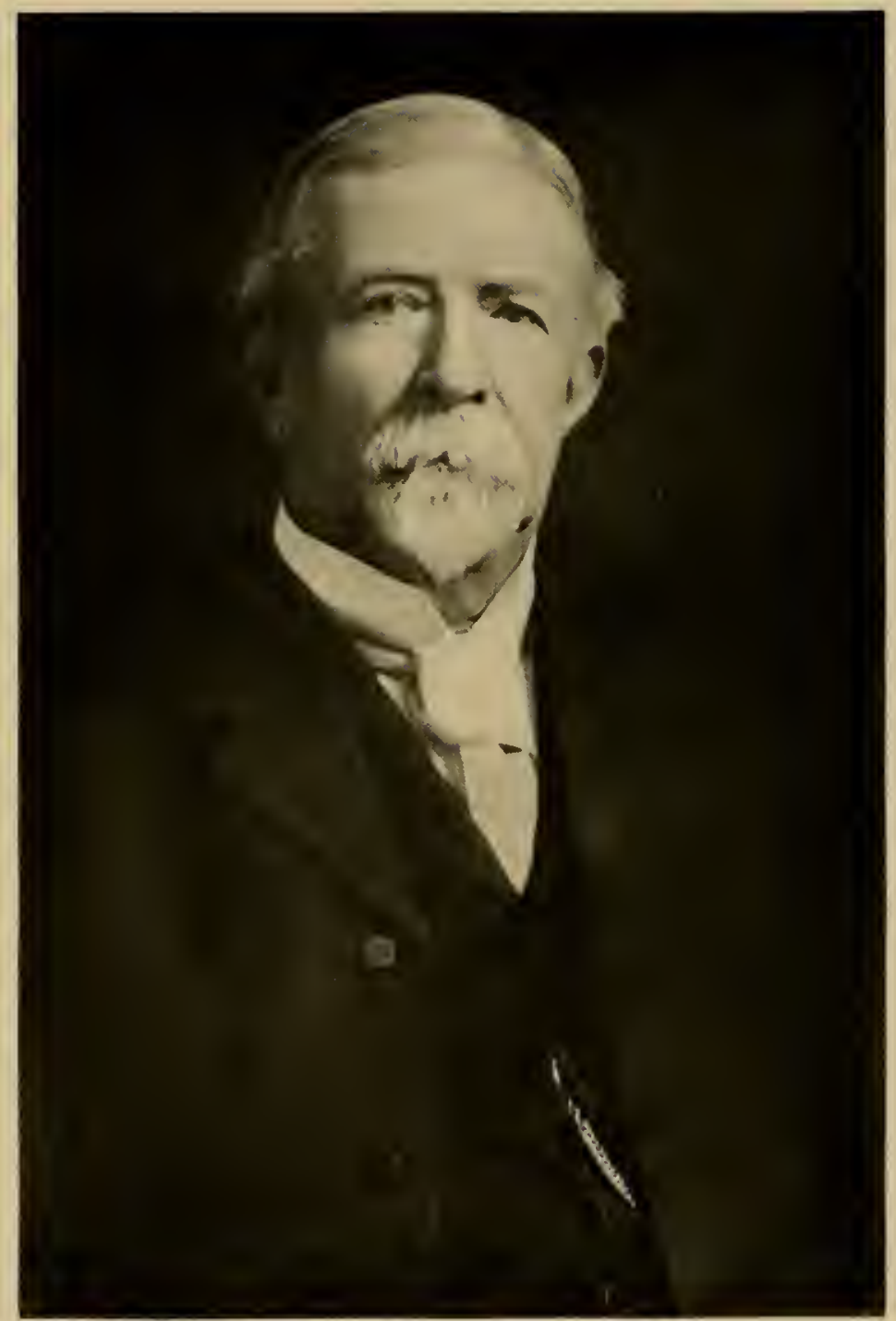

GEORGE LINCOLN GOODALE 1839-1923. Member I 875 .

President, May 6, 1891 , to May 4, 1892. Second

Vice-President, Mlay 4, 1887, to Nlay 7, 1890. 
of its class in this country to grent a salary, even though it be a small one, for investigation....

"I wish I could feel confident that in the years to come there would be a salaried investigator in every department of the $\mathrm{Mu}$ seum, working as Professor Crosby now does in Geology. My only remaining desire, in that case, would be that they might be paid in proportion to their deserts and not, as now, in proportion to our limited income.

"The first duty of an institution like ours is to provide for the safe keeping of the collections committed to its care and to exhibit them in proper shape for the instruction of the public. Its income may be, as ours at present is, hardly sufficient for these practical purposes, but if it has no higher aim its progress rcill necessarily stop aith the final reports on each department, and its museum will specdily, fall far behind the perpetnally progressing standards of other institutions.

"If, on the other hand, it aims to foster and cultivate investigattions which are appropriate and which naturally follow, after the practical work of caring for and exhibiting its collections is either partially or wholly completed in the different departments, it may pass by degrees to this higher level of occupation and possibly, finally make investigation its chief object. 'The entire museum will reflect such a spirit as this, and it may be safely asserted that its future will be better assured than by any policy of a more practical nature, which simply aims at the so-called completion of departments."

Again, in 1896, Professor Hyatt said:

"There is but little prospective benefit in attempting to build up New England collections which are simple masses of specimens that any man can collect and label. Each of the New England collec- 
tions should have a character of its own, derived from the investigations of the person who made it. 'They will then possess a teaching capacity and an influence derived from the labors of the investigator's who made them, that will extend widely throughout the community. The Geological department is an excellent illustration of what may be done. 'This, in combination with the work of the 'Teachers' School of Science in the same direction, has created a general interest which fills our lecture rooms whenever this subject is being taught. 'The number of original publications issued, and the interest felt in them and in the Geological collections are greater to-day than they have ever been, and are steadily increasing.

"The same effect may be produced in every department by the use of the same methods that have been so successful in the teaching and investigation of the Geology of this neighborhood, and the most important of these steps has been the last, the payment of a salary for the investigation of the Geology of the Boston Basin."

\section{The Fifty-Seventh Milestone I 887}

TE'T us pray in aid an independent witness of the fibre and temper $\perp$ of our early predecessors who lavished their enthusiasm on our Museum. A writer of a very illuminating article in the Sunday Herald of April 17, 1887, bears this testimony:

"The Society is significant in its origin as having numbered among its founders and active members the men who laid the foundations of the present earnest study of Nature in our community. One may read with a certain glow of enthusiasm of those public-spirited citizens, professors in colleges, physicians in practice, business men with large interests at stake, teachers with successful schools, very 


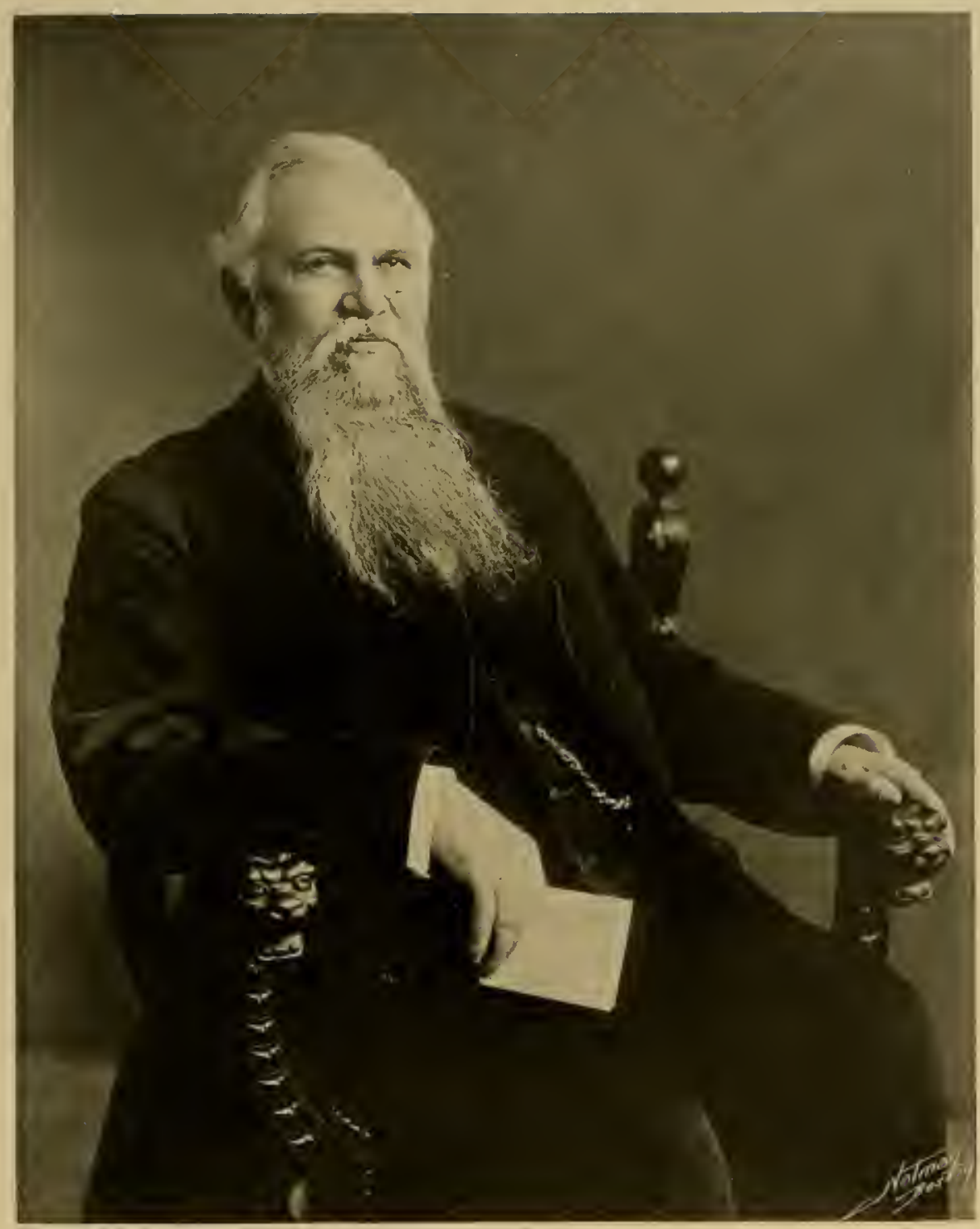

WILLIAM HARMON NILES

1838-1910. Member 1862.

President, May 4, 1892, to May 5, 1897. First

Vice-President, May 7, 1890, to May 4, 1892. 


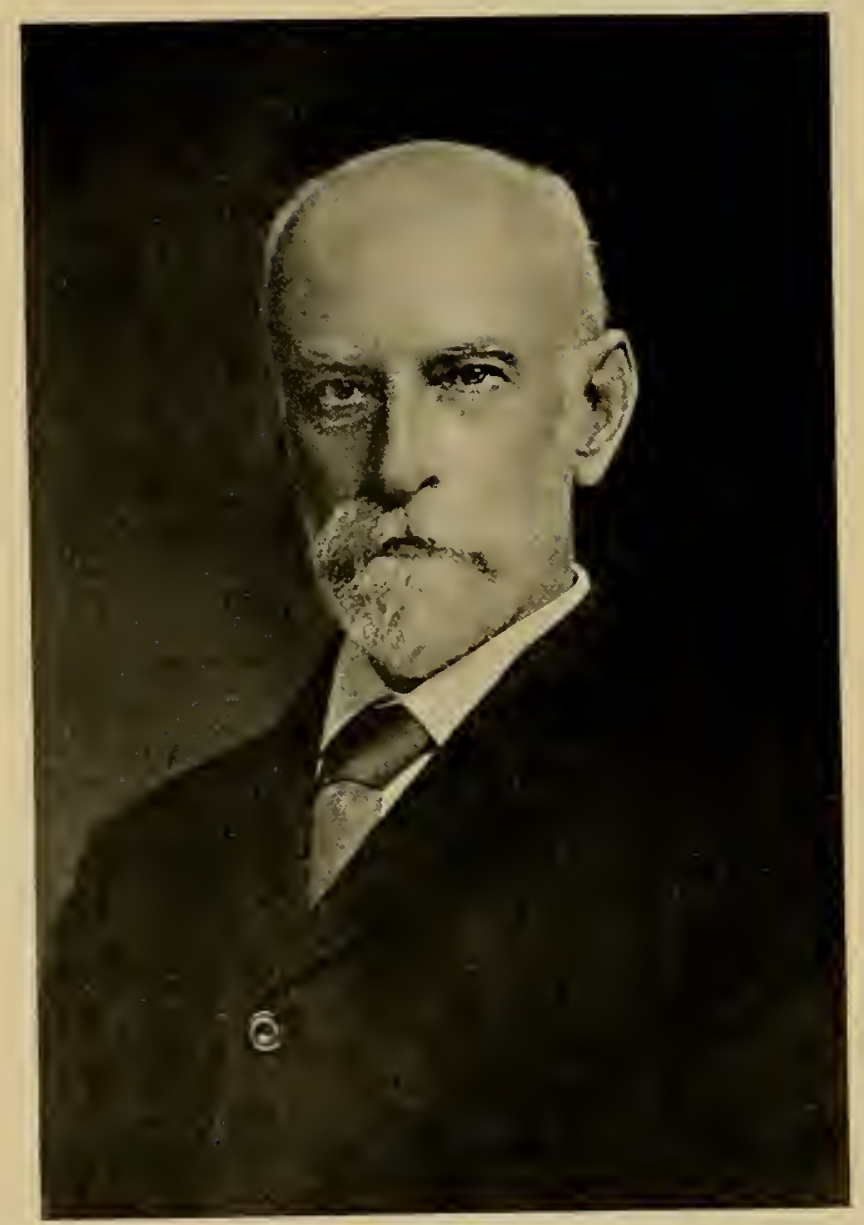

CHARLES SEDGWICK MINOT 1852-1914. Member 1868.

President, May 5, 1897, to November 19, 1914 (died in office). Third Vice-President, May 4,1892 , to May $3,1893$. 
few, if any, of whom were able to derote themselves exclusively to the study of subjects which were of essential interest in such a society, and yet were its founders. 'The story of their struggle is one well worth the study, and cannot fail to excite wonder at what was accomplished. In those times, the social organism had not reached the high pressure point of specialization which now forces all men of ability to concentrate themselves more than is, perhaps, best for their own fullest mental development and the enjoyment of life. A man, it would seem, should have a profession for recreation as well as for work. 'These men had, in addition to their usual avocations, a profession for recreation, and to such good purpose was it followed out that the present Socicty, its fine building on Berkeley Street near Boylston, adjoining the Rogers Building of the Institute of Technology, and all it has donc, directly or indirectly, have flowed from their exertions. . .

"Some of the members, as Mr. Bouvé informs us, came to the rooms habitually at five o' clock in the morning during fine summer weather, and finished a day's work in science before going to their own offices which was at an hour in the norning before that at which many people nowadays get out of bed."

\section{The Eighty-Ninth Milestone}

rgrg

GOR many years it had been the policy of the Society to open the 1 Museum free to the public on two days in the week and to charge a small admission on other week days. In 1907, the Society opened the Museum for three hours on Sunday afternoon and was gratified at the large attendance of people who showed their appreciation of this privilege. In 1919 it was decided to throw the 
Inseum open to the public free of admission fee, and this policy has since been maintained. Commenting on this departure, Dr. Edward Wigglesworth, Chairman of the Executive Committee, in his annual report for the year 1919 said:

"A new arrangement has been instituted during the year. For the first time the Museum has been open without charge every day of the week. 'This makes the collections available to everyboly at any time and therefore increases the usefulness of this Society,many fold. 'This policy of being open free at all times is the one now adopted by most Museums in the country. As a result and also in part due to the improvements and excellent condition of the Museum, the attendance has greatly increased during the past few months. On Sunday afternoons we now frequently have over one thousand persons where formerly only four hundred to fire hundred came."

\section{The Last Thirty Years}

FreER Professor Hyatt's death the Musenm found itself at
the turning of the ways. The old building was fearfully orercrowded and for years stress had been laid upon supporting research work, since the available funds would not allow both this to be done and, at the same time, permit the exhibits to be decently kept up.

There was much to be said in defense of this policy. The prestige of the Society abroad was well maintained and many important papers were published but the Museum became literally a "chamber of horrors." From this period dates the still prevalent idea that the Museum consists of a lot of overcrowded, mouldy rooms filled to overflowing with natural objects, good, bad, and indifferent. 'The shortage of storage space had, with the passing of many years, caused 


\section{Milestones}

every sort of object to be jammed into the exhibition cases. The IIuseum still, even at this date, accepted the care of material of every sort. The result was a fearful hodge-podge of ill-cared and often repulsive exhibits which belonged by right in a medical school or some repository other than a public exhibition.

At about this time it likewise bec:me erident that the fields of the MIuseum in Boston and the University $\mathbf{I}$ useum in Cambridge were both being cultivated in much the same way. This should never have been allowed to occur, but the group of young men who began to take their places on the Council, from fifteen to twenty years ago, were faced with a fact and not a theory, and "taking the bull by the horns," the Society's Museum, and, indeed, the Society itself, was completely reorganized. The Boston organization devoted itself entirely to the exhibition and study of the geology, faluna, and flora of New England while the Museum in Cambridge accepted the care of the general exotic collections and transferred its New England material to Boston.

After this difficult and laborious task was accomplished, the modernization of the Boston Musemm began, and it is to-day a crying shame that so large a part of the intelligent public of Boston does not realize that they have a Iuseum which, considering the means available, is a gem and an asset of which the City should be highly proud. Although starved and neglected, it is now clean, attractive, well labelled, and astonishingly rich in specimens of unique value.

We have reason to believe that a misapprehension exists in the public mind in regard to the sources of our finaucial support. Many people think that our Museum is supported by State funds. Such is not the case. The land on which our Museum stands was kindly granted by the State in 1860 , but our M I useum has been maintained through the generosity of a comparatively small number of public- 
56 Boston Society of Natural History

spirited citizens. In our hundred years of history, our Socicty has not made a public appeal for finds.

Among the well-known men who have belonged to our Society, in addition to those mentioned elsewhere, the following names occur:

\author{
Spencer F. Baird \\ Alexander Graham Bell \\ Charles W. Eliot \\ Ralph Waldo Emerson \\ Edward Everctt, Governor of Massachusetts \\ Edward Everett Hale \\ 1)r. Oliver Wendell Holmes \\ Josiah Quincy, President of Harvard 1829-4.5 \\ Professor Willian B. Rogers, Founder and \\ First President of 1I. I. T. \\ John Sargent \\ Henry D. Thoreau \\ Edward Tuckerman, famous botanist for \\ whom 'Tuckerman Ravine, Mt. Washing- \\ ton, was named
}

The following members have belonged to our Society for over fifty years. The date of joining is given after each name:

Dr. William L. Richardson

1864

Mr. Augustus Hemenway

1869

Mr. J. Henry Blake 1870

Dr. William N. Bullard

1870

Mr. James H. Emerton

1870

Mir. Samucl Henshaw

1871

Dr. George Dimmock

1874

Miss Jennie MI. Arms (now Sheldon)

$18 \% 6$

Miss Harriet E. Freeman

$187 \%$

Miss Susan Minns

Miss Eliza D. Boardman

1879

Prof. Mary A. Willeox

1879 
Names which constantly occur in our membership during the last hundred years:

\begin{tabular}{|c|c|c|}
\hline Abbot & Copeland & Lawrence \\
\hline Albbott & Curtis & Lee \\
\hline Adams & Cushing & Lodge \\
\hline Agassiz & Dana & Loring \\
\hline Ames & Dane & lothrop \\
\hline Amory & Dexter & Lowell \\
\hline Appleton & Draper & Lyman \\
\hline Ayer & Eliot & MacMillan \\
\hline Bangs & Emerson & Macomber \\
\hline Bartol & Endicott & Mann \\
\hline Baylies & Everett & Minot \\
\hline Bemis & Forbes & Motley \\
\hline Bigelow & Foss & Oliver \\
\hline Blake & Frothingham & Ordway \\
\hline Blanchard & Gardiner & Packard \\
\hline Blaney & Gay & Page \\
\hline Bowditch & Goodwin & Paine \\
\hline Bradford & Gould & Parker \\
\hline Brewster & Green wood & Parkman \\
\hline Brooks & Guild & Pealoody \\
\hline Bulfinch & Hale & Perkins \\
\hline Bullard & Hayward & Peters \\
\hline Burgess & Ifemenway & Phelan \\
\hline Cabot & Higginson & Procter \\
\hline Cheever & Holmes & Putnam \\
\hline Choate & Homblower & Quincy \\
\hline Clark & II unnewell & Rockwell \\
\hline Clarke & Jackson & Russell \\
\hline Codman & Jeffiries & Saltonstall \\
\hline Coleman & Johnson & Sargent \\
\hline Coolidge & Kidder & Shattuck \\
\hline
\end{tabular}


58

Shaw
Shurtleff
Sprague
Stearns
Storrow
Strong
Thayer
Thomson

Boston Society of Natural History

Townsend
Treat
Tuckerman
Wadsworth
Walcott
Walker
Ware
Warren

Wrashburn

IVebster

Wreld

Wigrglesworth

Wild

Williams

Winslow

Wolcott

\section{The Hundredth Milestone}

$$
\text { I9) } 30
$$

$\bigvee \begin{aligned} & \mathrm{E} \text { wonder what l'rofessor Wyman and our other illustrious } \\ & \text { predecessors would say if they were on the scene to-day, of }\end{aligned}$ the amazing growth in the study of Natural History and of the present demands upon the capacity and resources of our Musemm. It is a fir cry from the hall orer the Savings Bank in 'Tremont Street, one hundred years ago, to our present handsome building which we must double in capacity if ace are not to fail in performing the functions achich our past achiecements impose upon us and achich the public hece a right to cxpect. Natural History has long since emerged from the status of a hobby, or a Science for the few, to a vital factor in the programme of any well-educated person. 'The easier access to Nature won by increasing facilities of transportation, the greater lcisure which people of all stations in life now enjoy, and our growing population throw an added, if pleasant, burden on our Socicty; for every town-dweller can to-day be a student of Nature at first-hand.

The peep into the past which we have taken in this little book reveals with a clearness which none may gainsay the nature of the work and responsibilities which lie ahead. 'The aims of our Society are founded in the rision and public spirit of its pioneers. As this 


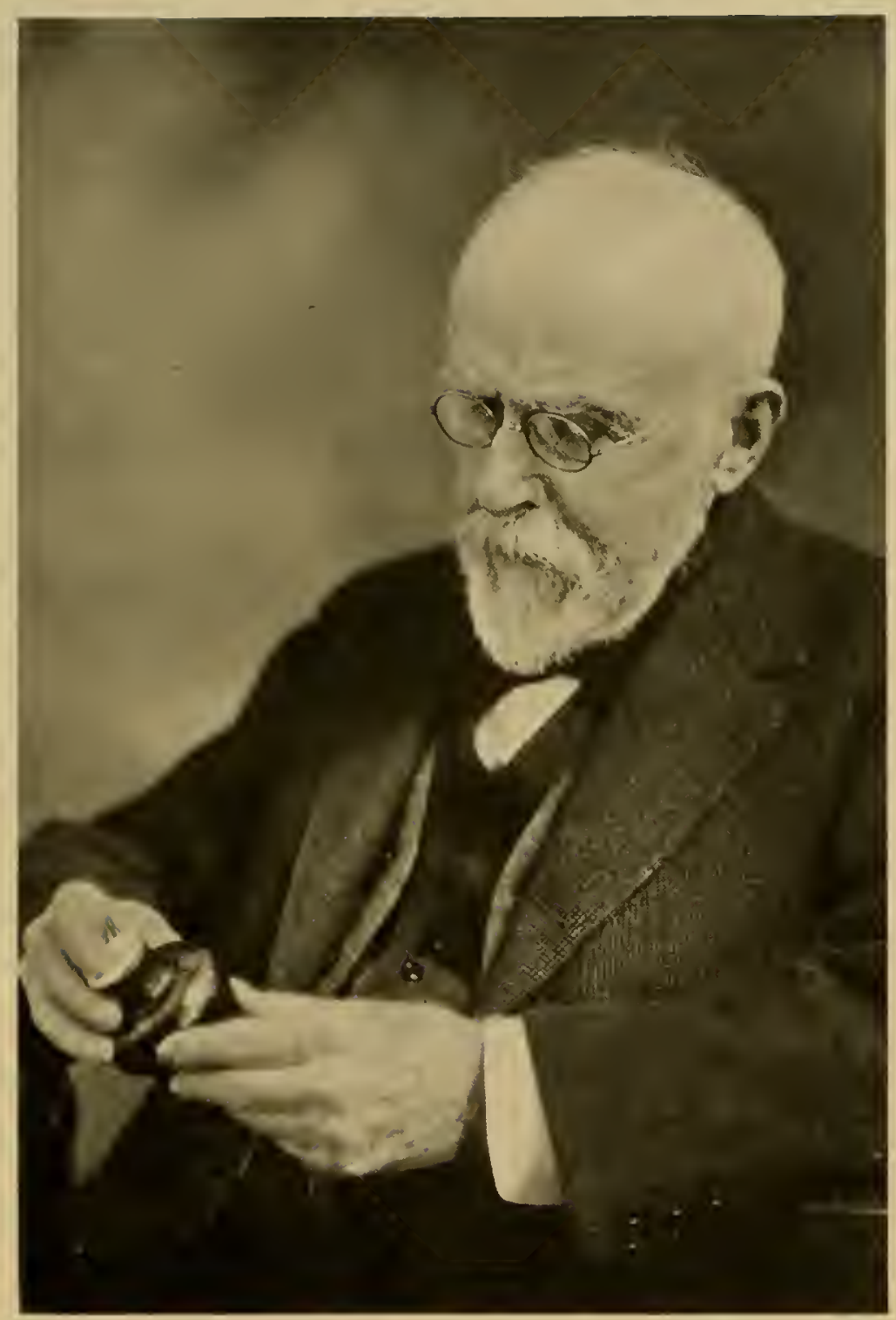

EDW ARD S. MORSE

$1838-1925$. Member 1859 .

President, December 16, 1914, to May 5, 1920. Curator of Conchology, May 1, 1867, to Mlay 4, 1870. Second Vice-President, May, 1898, to May, 1899. Third Vice-President, May, 1896, to May, 1898. 
brief retrospect shows, these aims have never varied. They are the warp and woof of our Society to-day, so that the problem before us is plain and straightforward. In order to live up to the ideals of our forebears we have to organize the expansion of plant, facilities, and personnel, for which the development of New England calls. It is up to the present generation to raise our Society to a standard of efficiency in the twin causes of Science and Education which will win for it a place second to none among kindred Institutions.

Our Society, as we have seen, decided, most wisely, to concentrate its efforts on a study of Nature's work in New England, a policy which is perhaps mique among kindred institutions. New England is a field large enough and rich enough to need an institution wholly devoted to the study of its natural phenomena. The foundation of our work is thus laid on lines which only call for expansion-not demolition or alteration - to bring our Museum into line with the need for the greater service and facilities which are now overdue.

We have for some time been carrying on with inadequate financial resources, but we have cheerfully struggled along with cramped means because we felt that our Hundredth Milestone was the point at which it was in every way appropriatc that we should ask for help to carry us on past many another Milestone.

As our forefathers, in founding the second oldest Natural History Society in America did their duty by us, so we are bound in the same spirit to do likewise by posterity.

Our Centenary, as it happens, coincides with the Tercentenary of our State, so the urge to show our gratitude to the men who hewed Massachusetts out of the wilderness. by doing in our turn a work for which posterity will thank us, is doubly stimulating for those of us who reverence the mighty part which Massachusetts has played in the development of our country. 


\section{Milestones}

"They builded better than they knew." May those who come after say the same of us. What story will they lave to tell at the two-hundredth milestone?

O Lord, how manifold are thy works! In wisdom thou hast made them all: the earth is full of thy riches. So is this great and wide sea, wherein are things creeping inmumerable, both small and great beasts... Thou sendest forth thy spirit, they are created: and thon renewest the face of the earth. 


\section{JOHN JAMES ALDLIBON}

Audubon spent the winter of 1832 and 1833 in Boston. His closest friends in Boston were among the members of the B. S. N. H., such as Dr. Thomas Brewer, Dr. 13. 1). Greene, Dr. George C. Shattuck, Dr. John C. Warren, Dr. Augustus Gould. It was during this winter that he became a member of the Society. He was also in Boston during part of 1836 . The B.S. N. H. subscribed to Audubou's Birls of America, various members each subscribing so much toward its purchase. Col. 'Thomas H. Perkins, who was one of these subscribers, later gave the whole work (consisting of four folio volumes) to the Society, who sold its copy on receipt of this gift. The cost of these books to-day could hardly be estimated, and the Society's set is kept in a special locked case. Much material used in these books was obtained from the Society's members.

During the winter of 1832-33, Audubon became critically ill because of overwork, and was nursed back to health by Dr. George Parkman, Dr. George Shattuck, and Dr. John C. Waren. The last two were active members of the Society.

Healy, in his Reminiscences of a Portrait Painter, says of Audubon's portrait:

"When I was in London as a very young man, in 1838, the great naturalist Audubon visited the British metropolis. He was received with delight by all the American colony, and I naturally took part in that demonstration of enthusiasm.

"Audubon was of French extraction, born in New Orleans, but his family for two generations had been American citizens. He was a very simple man, a little rough in appearance, with long shaggy black hair, and the most piercing eyes I ever saw, - real eagle eyes.

"I called upon him and asked him to sit to me. He assured me that though he was greatly Hattered, he could not possibly spare the time. He had come to London to bring out his big book on birds, and was too much absorbed by this work to think of sitting. 'Then, as he was a kindly man, he added: 'I have but my evenings to offer to you.'

"Doubtless he thought to escape me in that way. But artists are perserering: I am peculiarly so.

"'The very thing, my dear sir! I shall make an original portrait by gas-light."

"The great man was caught, and very graciously accepted his defeat.

"I painted him in a costume he wore when he went in search of his birdsa sort of backwoodsman's dress. The portrait was a curiously bright one, as though it had been painted in full sunshine.

"In the course of conversation Audubon discovered that I was in love with a young English girl; he became at once very firiendly and communicative, assuring me that a good marriage was the only real happiness one could hope for in 


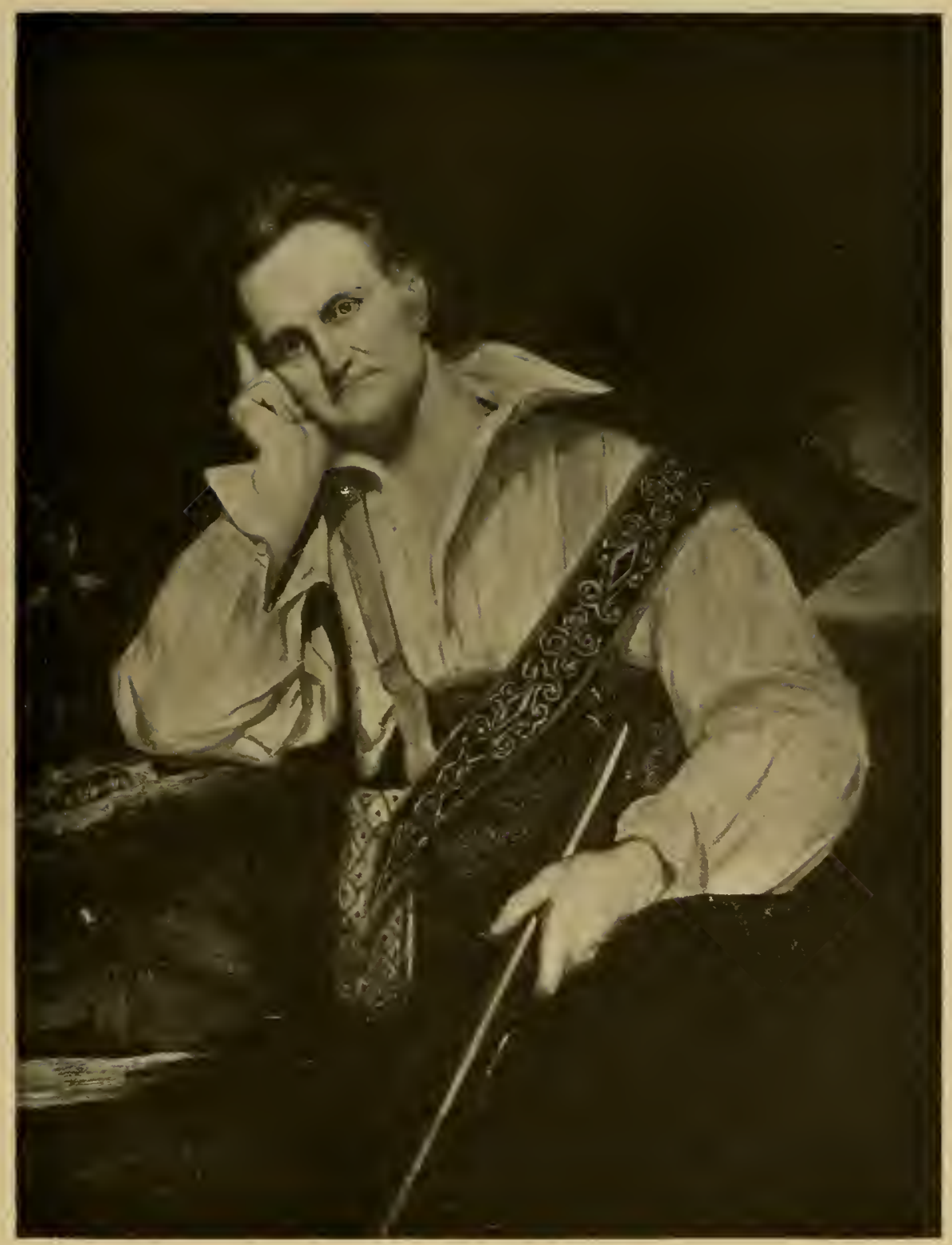

$$
\begin{gathered}
\text { JOHN JAMES AUDUBON } \\
\text { 1780-185 I. }
\end{gathered}
$$

Elected to Corresponding Membership in the B. S. N. H., December 5, 1832. Elected Honorary Member, November 3, $18+1$. 


\section{4 \\ Boston Society of Natural History}

life. And he told me how he had married a governess, as poor as lie then was himself, and how absolutely happy they had both been, in spite of all the material difficulties they had encountered. High culture and a loving heart are the only treasures that are not subject to ruin. He found me a willing listener, and easily convinced of the truth he so eloquently preached."

'The following letter from Audubon to D. I Imphrey Storer (the original manuscript of which is in the Library of the Boston Society of Natural History) is of interest:

Mr Dean Sir.-

New Tork, Fcby. 10th 1843

My Son Victor brought me, this evening Your letter dated Jany 2 ith, where it has traveled is more than I can tell.-

I am a good deal astonished at what $m y$ good Friend $\mathrm{Wm}$. Farrell says to you; for I can assure you, that when I left England in all probability for the last time, Thrce Iears ago, he never gave me any Book or any letter for you! Ind he done so, you would have received them long since.

I am sorry for the disappointment this may occasion to you but cannot help it, and I can only say to you, that your only remedy is to write to Mr. Farrell to send you, another Copy of the same papers. - It is curious after all that in his last letter to me received by the last steamer from England, My Friend does not allude to what he says to you on this subject. -

I shall not leave this City on my way to the Rocky Mountains until the 10th or 12 th of next month.

$$
\text { Believe me ever, My Dear Sir }
$$

With great sincerity Your Friend \& Servant

Јонх Ј. Audubon

P.S. On speaking of your letter to my family, they all observed that we started from Edinburgh and that we did not see Mr. Farrell for one year previously to our departure.-

To D. Humphrey Storer, Esq., M.D. 


\section{II \\ THE MLISELIM AS IT STANDS $T O-D A Y$}




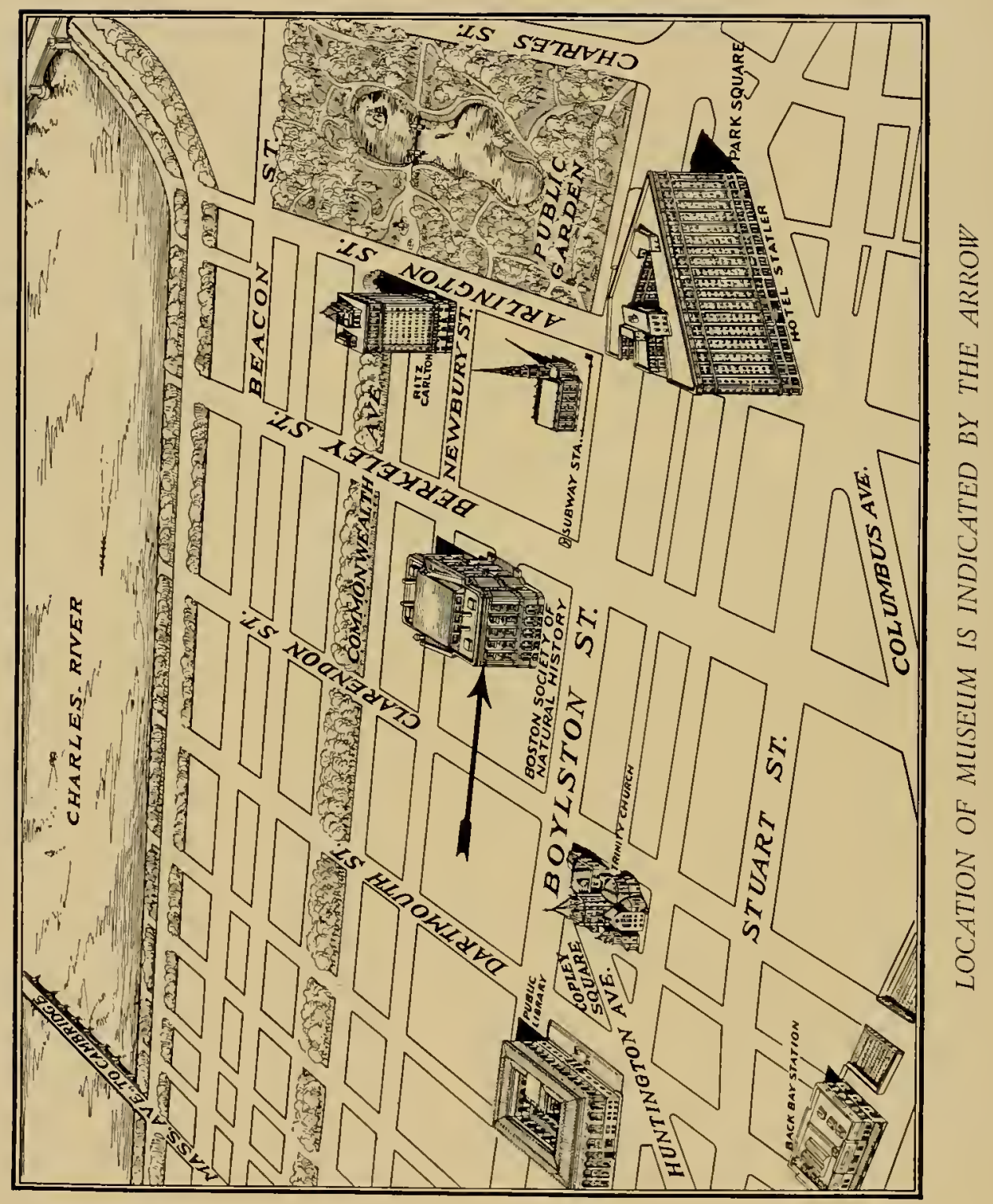




\section{OFFICERS}

PRESIDENT

Charles H. Taylor

VICE-PRESIDENTS

Nathaniel T. Kidder

Glover M. Allen

William M. Wheeler

SECRETARY

TREASLRER

Clinton V. MacCoy

Augustus P. Loring, Jr.

DIRECTOR

Edward IVigglesworth

BOARD OF TRUSTEES

Glover M. Allen

Thomas Barbour

Joseph A. Cushman

Laurence B. Fletcher

Frederic H. Kennard

Nathaniel 'T'. Kidder'
Augustus P. Loring, Jr.

W. Gordon Means

John C. Phillips

Charles H. Taylor

William M. Wheeler

\section{MUSETM}

Charles IV. Johnson, Curator of Insects and Mollusks

Edward Wigglesworth, Curator of Geology and Mineralogy

Robert T. Jackson, Curator of Paleontology

Harold L. Babcock, Curator of Reptiles and Amphibians

S. N. F. Sanford, Curator of Marine Invertebrates

John D. Smith, Preparator

Isabel Hoopes, Assistant in Herpetology

\section{LIIBRART}

Mary B. Cobh, Librarian

Calista Harris, Assistant
PUIBI,ICATIONS

Glover M. Allen, Editor

Dores P. Underhill, Assistant 


\section{The Museum as it stands To-day}

$A_{\text {woven of the spirit and mind of those who have labored faith- }}^{\text {MIUSEUM is an essentially human organim whose soul is }}$ fully to unfold the marvels of Nature. Even in these machineryridden diys, so human, so fine, and so individual, is the contribution which builds the growth of a Museum that the mind of man cannot invent a machine to supplant the necessity of his personal efforts. A soul of a Museum is a thing of slow and gradual growth, a thing which in course of time creates its own enrironment and atmosphere. It is beyond the wit of man or the resources of wealth to improvise a Museum of Natural History.

We have a background of one hundred years of the patient selfsacrificing work of many whose names stand on our roll of honor and of many whose names are forgotten, but who labored faithfully and well in the cause of Science and of Education. At the end of a hundred years we may from our hearts hail with grateful remembrance the devotion of those who have gone before, and of those who are still with us, which has made our Museum what it is to-dayan institution of which Marssachusetts and New England may be proud.

We are entitled to claim that our Museum contains really valuable collections of the Natural History of New England. These collections are scientifically arranged and attractively displayed in logical order. They are all in first-class condition. But our material considerably overflows the space available, and the urgent necessity for a much larger building confronts us in every Department. There is, besides, much ground in every branch of the Natural History of New England, excepting, perhaps, Ornithology - still to be explored. It will take years of scientific effort to make our collections 


\section{The Museum as it stands To-day}

complete and thoroughly representative of the whole New England field. We will let the following descriptions of our different Sections speak for themselves.

\section{The Library}

$\mathrm{O}$ UR Library is the second oldest of its kind in American and without seeking to draw invidions comparisons we may say that its growth during the one hundred years of its existence has been characterized by a high standard in the quality of its contents.

Our Library contains 52,110 volumes and 47,149 pamphlets, besides a large number of incomplete volumes of serials. We are so fortunate as to possess works which are not to be found in any other library in New Englend, and which are eagerly sought by students in different lines of scientific research.

The founders of the Society recognized at once the importance of having a library of reference works ready at hand for consultation, and voted in January, 1831, to appropriate funds for a "library of works," consisting of the best elementary books in various branches of Natural History. At that time there were comparatively few dealing with American Natural History, so that it was not always easy to find literature concerning the native animals and plants. In 1834 was issued the first number of the Society's Journal which became al medium for the publication of original researches by its members. At once an exchange list was established, and many other scientific bodies sent their publications in return for the Journal. 'Thus began an ever-increasing list of scientific transactions until, with the addition of new exchanges as other institutions for the study of Natural History arose, the total number has now reached about five hundred and continues to be not only a means of diffising the latest results of study, but also a large factor in the steady growth of 


\section{0

the Library, which now includes sets of the publications of the world's leamed societies extending back over many years. The second chief source of books in the Library has been through the generous gift of members and friends who latre from time to time made valuable donations or have bequeathed their private libraries. There are many such, as in $\mathbf{1 8 4 5}$, a gift of fifty volumes from Dr. Francis Boott of London; the bequest, in 1855, of the library of Jimes Brown, who, long a generous benefactor, left to the Society his splendid collection of expensive works on birds; the fine library of Amos Binney, a former president of the Society, was donated by his widow; and in 1863 came similarly the large botanical library of Benjamin D. Greene, comprising over fifteen hundred vol umes. In its earlier years, too, came the help received from an organization known as "A Republicun Institution," which, in 1849, not only gave the Society the use of income from one-lialf of its fund of $\$ 2,500$ for buying books, but later deposited in the Society's Library its other books on travel and Natural History. When in 1864, Samuel H. Scudder became Librarian, he devoted great energy to increasing the number of exchanges, and during a visit to Europe did much to perfect the series of publications thus received. At his death he left his wonderful private library of entomological works to the Society. More than any one else he was the means of putting the Library in the high place it now holds. His work has been continued by his successors, and his generous eximple has been followed, so that although the amount of money annually spent for books lias been very small, the exchanges and bequests receired have sufficed to keep our standard high. Yet more and more, with the annural increase of literature and the growing demands for binding, it becomes difficult to keep pace with bare necessities.

The Library is devoted to Natural History in its wider sense and 


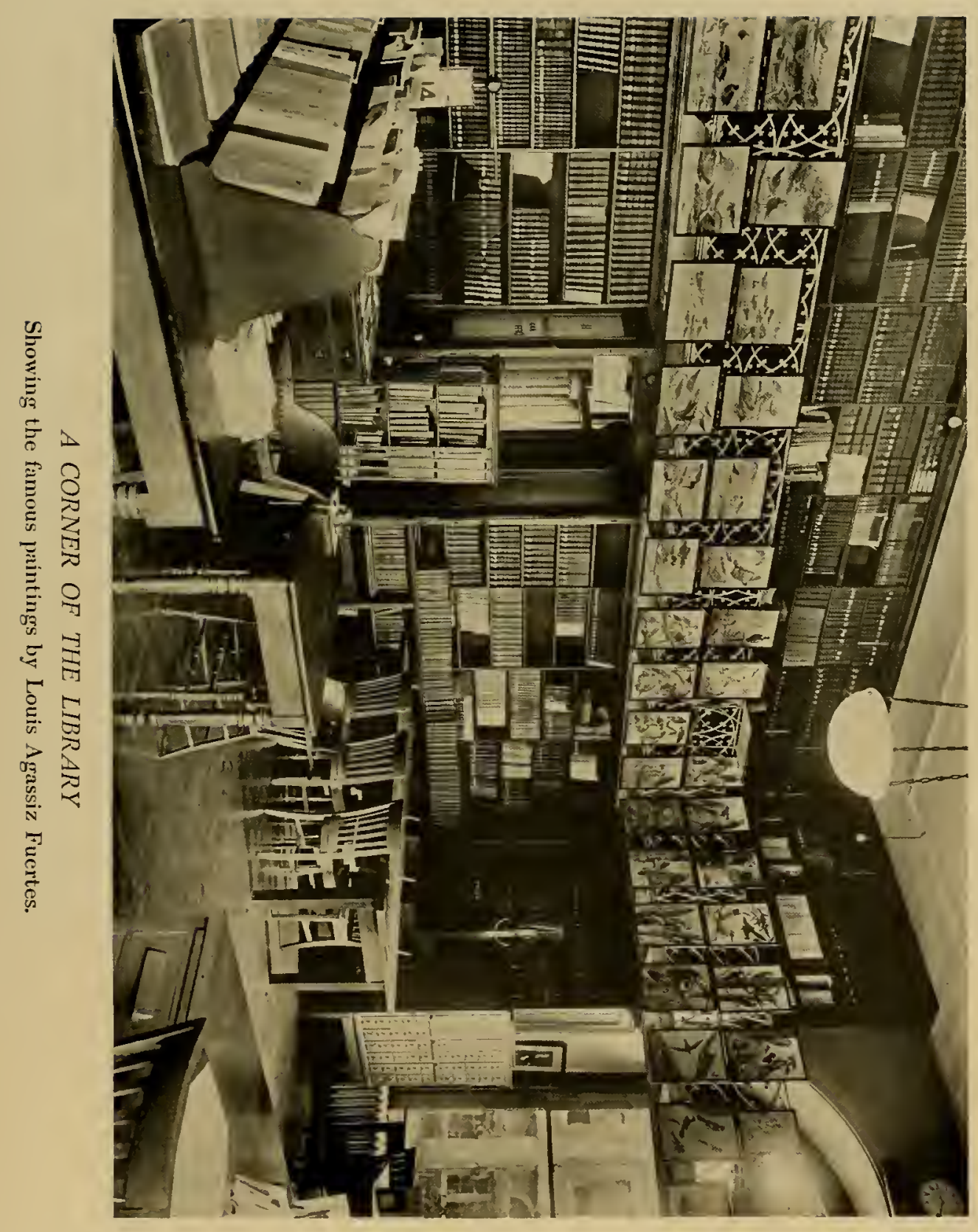




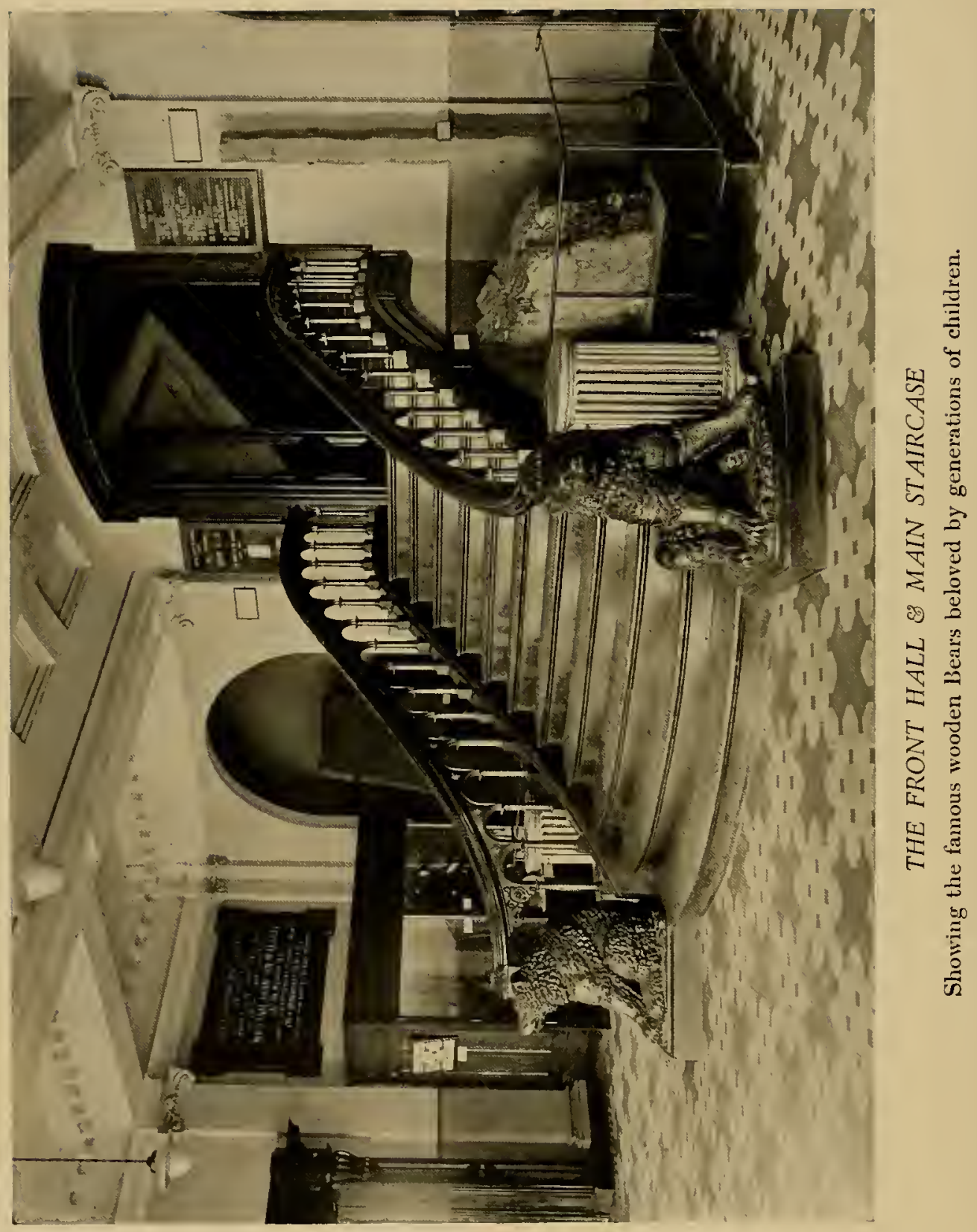




\section{The Museum as it stands To-day}

contains many sets or single volumes, notable for their rarity, value, or beauty. Among the last are the beautiful sets of original elephint-folio plates of Audubon's Birds of America and the Quadrupeds. Hardly less elegant are the complete works of Gould, including sumptuously bound monographs on various groups of brilliantly colored birds, such as the hummingbirds and the toucans, illustrated by magnificent colored plates in folio size. There is also a copy of the rarer volume on the Odontophorine or quails, and a set of the Birds of Australia. The earlier classic works of Wilson and of Catesby, the former on birds, the latter on plants and animals of the Carolinas, are also represented. Several volumes of colored figures by Abbot, illustrate the birds and insects of Georgia, and are exceedingly rare if not almost unique. Other older works include beautifully illustrated volumes on shells, such as the series of Reeve's Conchologia Iconica and the Conchyliornum Cabinet of Martini and Chemnitz. More modern works of great beauty and value are the series of volumes of the Biologia Centrali-Amcricana, the Flora of Brazil, Sargent's Sylva, and others too numerous to name in a brief paragraplı. Then there are many sets of the transactions of learned societies, some of whose publications extend back for a century or more. Special efforts have been made to complete the more valuable of these, so that some at least are more nearly perfect than are to be found elsewhere in the vicinity. Others are less ancient but rare in this neighborhood, such as the fine series of illustrated volumes of the Bombay Society of Natural History. Numerous old works of a bygone day are represented, whose value lies in their quaintness or other historic importance as source books, or records of the beginnings of a more exact knowledge of Natural History. Among these are the great volumes of Gesner's Natural History, written in Latin and Greek, with quotations from 
the writers of antiquity conceming the animals known in a past century, for it dates from 1555; while a second work of the same date and of equal importance is the volume on birds by the French savant, Belonius, almost the first treatise on this group of animals. 'There are numerous works on insects that are equally valuable through their rarity and historic association. Examples are the little book by Bilberg on the insects of Scandinavia, and one by the German, Hiibner, on butterflies, while another almost unique copy in this part of the world is Koch's series of hand-colored plates and text issued on separate sheets of small size, monographing the mites and allied types, nearly a century ago. Several of the rare works of Peter Pallas, an illustrious pupil of the great Linnaeus, are here also, and include the results of his early investigations in the Natural History of Siberia and northern Asia.

For a good many years the Society has made a special effort to secure all publications relating to the Natural History of New England, for some of these date back to early times. Thus, John Josselyn's New England's Rarities Discovered is with its comments one of the most fruitful of our slender sources of knowledge concerning the natural conditions here in the years immediately after the settlement. IVe have a modem reprint of this. The older geological reports of the New England states are full of interesting notes, while some of the publications of the earlier scientific societies such as that of the Hartford Natural History Society, are exceedingly rare. Nearly a century ago there was a society at Concord, New Hampshire, whose only publication seems to have been a small pamphlet on the cocoanut. 'The only copy in existence appears to be that in the State Library at Concord, but we have had a photostat copy made in order that it may be represented in our collection. Our "local lists" of birds are unusually numerous. 


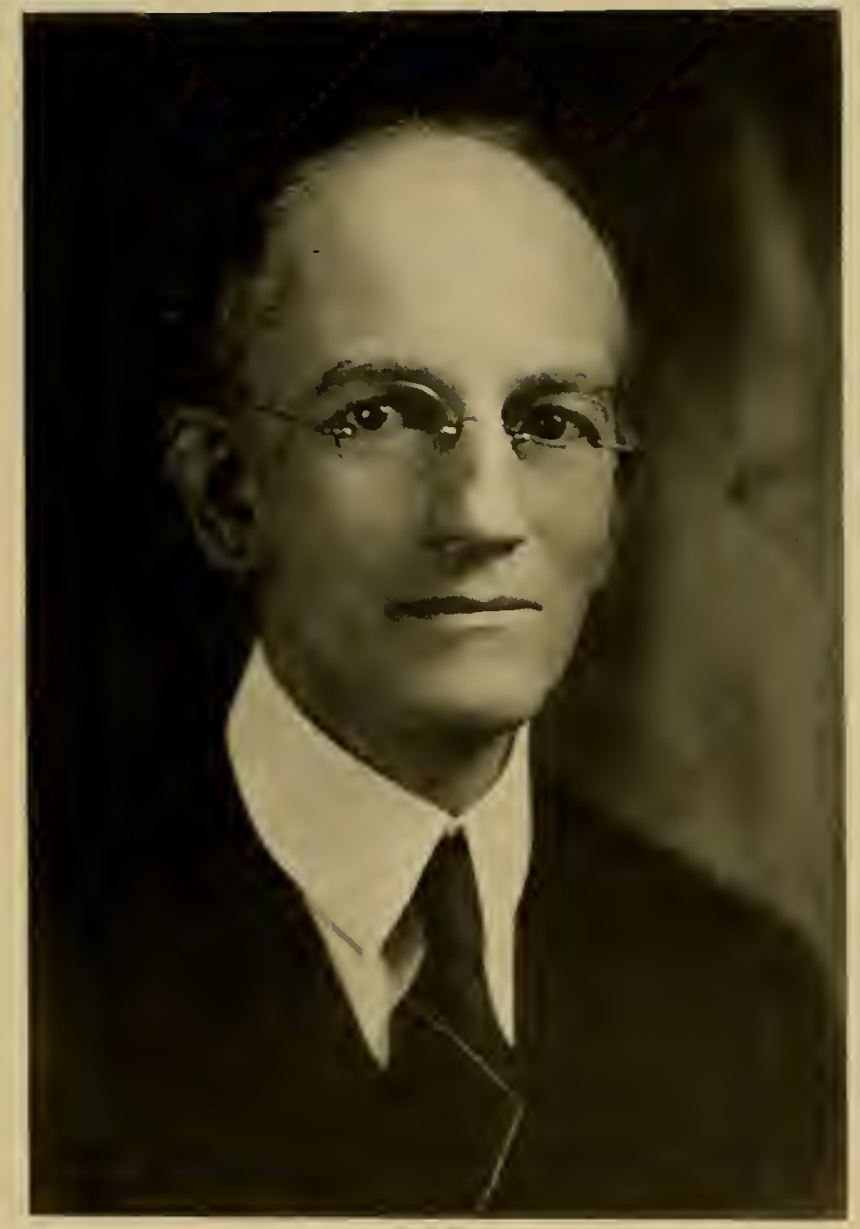

\section{GLOVER M. ALLEN}

Vice-President, 1928, to present timc.

Secretary, 1901-1924. Librarian, 1901-1928. 
The housing problem has, from time to time, become acute, but always there has eventually come some means for relief. In 1839 , the small but growing collection of books was housed in the Librarian's private rooms on'Tremont Row, where its seven hundred volumes might at all times be accessible to members. With the opening of the present building, the space allotted in $\mathbf{1 8 6 5}$ seemed wholly adequate for a generation, but in another thirty years it had ontgrown three large rooms, including the present basement room, reached by a flight of lighthonse stairs. Within the last twenty years, the great valne of the Library and the bope of gaining more room by the installation of less bulky furniture led to the construction of a specially fire-proofed stack room with modern steel stacks. The generous gifts of a few members have of late greatly helped to pay for necessary binding of paper-covered journals and transactions of societies, as well as in recent years to supply attractive tables and chairs for the use of readers in place of the few ancient pieces inherited from mid-Victorian times. Now again, the growth of the Library has reached about the extent of its quarters, the use of it has increased many fold over what it was a few years since, and a wider usefulness is hampered by the need of greater facilities for housing and binding the books and procuring many that cannot be secured except by purchase. Part of this increased use comes from the general public, for whereas in days gone by, the books were for the use of nembers only, a privilege exercised by few, now the public is allozced to consult the Library and its staff and resources already are inadequate to meet the need.

Professors assigu lessons and their stndents come to us eagerly, armed with references. We are told that nowhere else in the vicinity are such books available. With touching confidence the stranger expects us to have all the good books on birds, ferns, or spiders. 
The Museum as it stands To-day

Why not? We occupy the position of leading Natural History institution in a large metropolitan district, a center justly famed for its Art Musenm, its Public Library system, its Symphony Orchestra, its schools and colleges. We are inevitably regarded as the city's official institution, in spite of the fact that we have to rely on private support. The modern youth expects to find in a great city all the opportunities for culture-expects it as unquestioningly as he expects to get good drinking water by turning a tap. Many of his elders are like-minded.

As far as our restrictions pernit and our funds carry us, as fast as we become known to those who need us, the Library is finctioning quietly and steadily. Many of the biological books which are published in this ricinity have been worked out with the help of our resources. Many a graduate student owes the groundwork of his doctor's thesis to our shelves. Artists get up magazine covers from plates in our books. Older people come here to revive the hobbies of youth, and find to their delight a mine of literature in their chosen fields.

\section{Sixty Famous Paintings by Fuertes \\ (Shoun in Pholograph of Library on page 71 )}

IN the reading room of the Library may be seen one of the rare Ireasures in the possession of the Society, namely the watercolor paintings of New England birds by Louis Agassiz Fuertes. Reproductions of these are familiar to a great number of bird students through Forbush's volumes, Birds of Massachusetts and other New England States, for which they were painted. To see the originals is worth a pilgrimage for artist or ornithologist. Both are wont to express indignation at the way they are hmig, for the railing around the balcony is obviously too high, either for close 
78 Boston Society of Natural History

scrutiny of details or for the best artistic effect. In our limited quarters, however, this has actually been the only place where they could be kept safely on view.

Library staff and visitors alike have profited meanwhile in this contingency. To work or read in the presence of these idylls of New England scenery is an inspiration. 'The backgrounds, whether of rocky coast, marshland, hills, or snow-covered meadows, are so characteristic that they bring to each one's mind some well-remembered spot; while the various attitudes of the birds — rising from the water, swooping through the air, strutting along the beach - provide endless diversity.

When, through the intercession of friends, the State Department of Agriculture consented to place these paintings permanently in our keeping, both artist and author expressed themselves as being much pleased at the decision. "I am deeply grateful,"wrote Fuertes, "that the pictures fall into such sympathetic hands as yours." With characteristic generosity he offered to keep them touched up from time to time as they might need it. 'This offer lacked fulfilment only through his tragic death in August, 192\%. We are thus left in possession of the last and in the opinion of Forbush himself the finest work of this prince of bird artists.

\section{Publications}

7 HE first publication of the Society appeared in 1834 , soon after 1 the Society went into operation. This was the Boston Journal of $\boldsymbol{N}$ atural History, "containing Papers and Communications read to the Boston Society of Natural History and published by their direction." These consist of seven volumes published from 1834 to 1863. 'The Journal was modelled by Dr. Amos Binney, and he had a paper in the first number. 


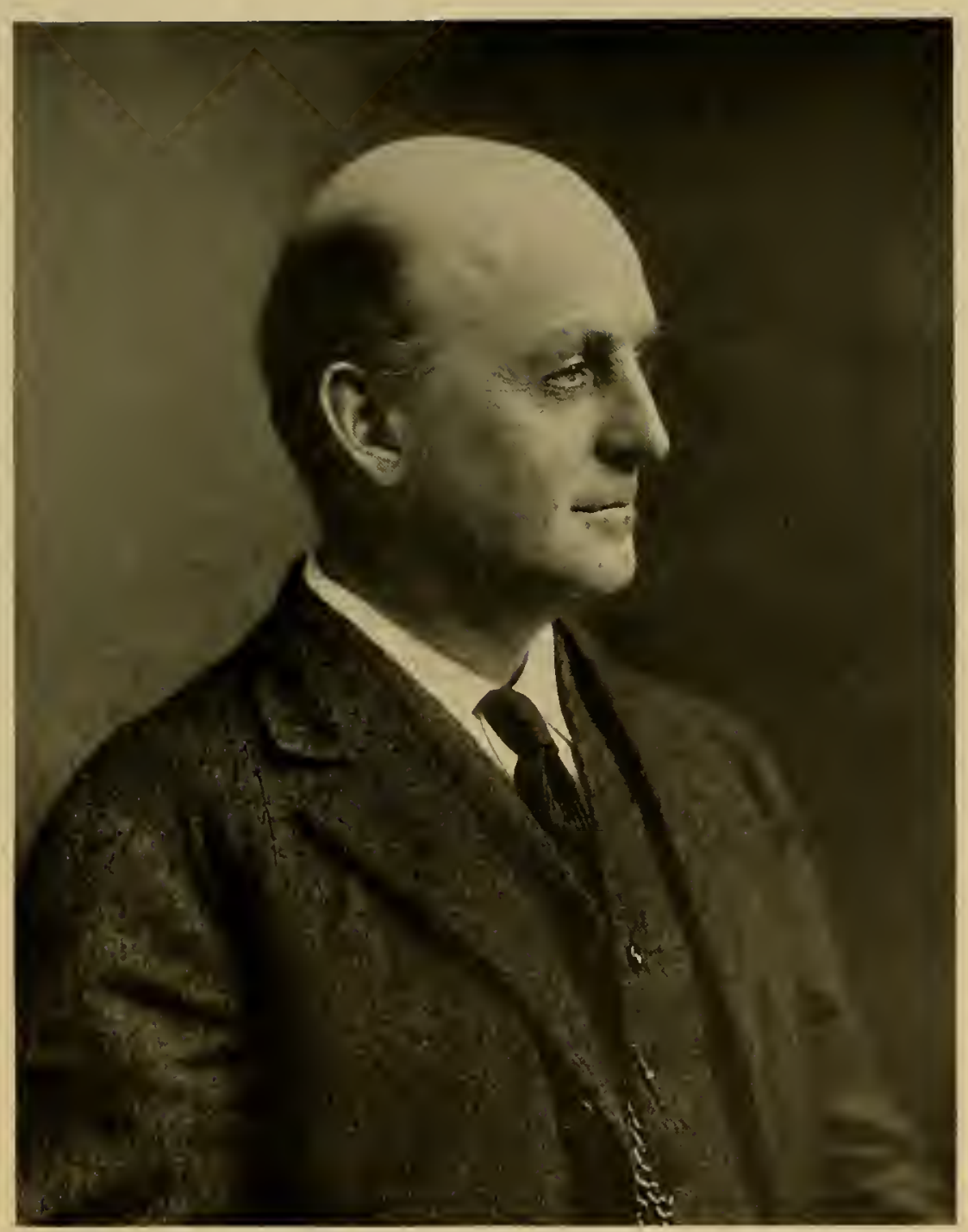

W. CAMERON FORBES

Presidcut, 1920-1925. 
The introduction in the first volume states, "'The Society under whose direction the present publication is made, having been established for the purpose of creating a taste for Natural History, and of affording the means of acquiring and diffusing among their fellow-citizens a knowledge of this branch of Science, have, in pursuance of the object of their institution, considered it advisable to publish such papers and communications as may come into their hands, possessing sufficient interest to entitle them to be laid before the public. Having but small claims to the character of Naturalists, they are nevertheless desirous of contributing something to the common stock of information, and they hope that the succeeding pages will evince the sincerity of their wishes and the industry and zeal with which they have pursued their attainment." And again, "While the Society looks to its own members for the principal part of the mitterials of the work, its pages will be open to the use of scientific men in every part of the country, and their countenance and aid is respectfully solicited." Such is the present policy.

'The first volume of the Journal contained papers by Augustus A. Gould, Charles T. Jackson, W. T. Harris, Thomas Say, D. Humphreys Storer, 'Thomas M. Brewer. Later papers were written by such men as Samuel Cabot, Edward Tuckerman, Samuel G. MIorton, Jeffries Wyman, J. E. Teschemacher, A sa Gray, John Lewis Russell, George Engelmann, Nicholas Marcellus Hentz, W. O. Ayres, John Gundlach, Alexander Agassiz, and Samuel H. Scudder.

A bout one-half of the articles relate to the Natural History of New England, the rest of the papers dealing with many other regions.

In 1842, Augustus A. Gould reported, "It is by its publications alone, that the Society can expect to be extensively useful, diffus- 
ing the facts gathered by its members, and securing to them their honest clue as original observers. The circulation of the Journal is now nearly sufficient to defray the expense of its publication; and the demand for it, especially from abroad, is rapidly increasing.

"The Society has also published and distributed, gratuitously, the discourses given at the annual meeting, by Dr. Walter Channing, Rev. H.Winslow, and.J.E. Teschemacher, Esq. Arrangements have also been made to publish an Abstract of the doings of the meetings in a form to be extensively and promptly circulated, as is now done by most other scientific bodies."

The first rolume of the Procecdings was published in 1844 and contained papers delivered before the Society from 1841 to 1844 . Throngh 1895, those papers printed in the Proceedings were read at the meetings of the Society. These go through Volume xxv1.

From 1896 (starting with Volume xxvi1), papers in the Proccedingsare those dealing with general Natural History. As time went on, the subjects in the Procecdings becane broader in scope. At the present time this publication is composed of more or less extensive papers on all the branches of Natural History. Each volume contains from four hundred to five hundred pages. Illustrations are frequent. Volume xxxix is now in progress.

In 1866 the first volume of the Memoirs was published, this "being a new series of the Boston Joumal of Natural History." The first paper in this was A Revision of the Polypi of the Eastern Const of the Lnited States by A. E. Yerrill. This was read before the Society on November 19, 1862. The early volumes contained papers by Elliott Coues, Samuel H. Scudder, Alpheus Hyatt, H. James Clark, J. A. Allen, Charles Sedgwick Minot, Edward S. Morse, Jeffries W yman, N. S. Shaler, C. R. Osten Sacken. These are 
quartos and contain extensive articles on many subjects, and most are fully illustrated. Volumes vi and viı are now in progress. Each volume contains from five hundred to six hundred pages.

Volume I of the Occasional Papers appeared in 1869. This volume contained largely entomological correspondence. Volume in contained the writings of Nicholas Marcellus Hentz on the Arachnida. Volumes II and iv contain a treatment of the Geology of eastern Massachusetts and the Geology of the Boston Basin by W.S. Crosby. Volume vi is a list of North American Orthoptera by Samuel H. Scudder. Volume vir, now in progress, contains faunal lists of vertebrates and invertebrates of New England. Volume v, now in progress, is devoted to descriptions of new species and shorter reviews of genera, species, etc.

Twenty-three numbers of the Museum and Library Bulletin were published from 1906 to 1914 . 'These contain notes about work in the Museum, progress of the Library, and short popular articles on Natural History.

This function was taken over by the Bulletin in 1915. This is an octavo, popular, illustrated quarterly of New England Natural History. Fach number contains from sixteen to thirty-two pages. 'These are distributed to all members. A new series of publications, the Natural History Grides was started this summer with the appearance of Guide $\mathbf{N}$ o. 1 on The Snalies of $\mathbf{N}$ ere England.'This is a small, popular, low-priced handbook which enables one to identify New England snakes. An extensive list of subjects is planned which will be embodied in future numbers of this series.

'The Proceedings, Mcmoirs, and Occasional Papers, and the Natural History Guides are published at irregular intervals. Publication of the Proceedings was begun in 1841, of the Memoirs in1866, and of the Occasional Papers in 1869. Most of the early volumes of 
these three series are still in print. Publications are furnished gratis to all members except Associates. A complete price list of the Society's publications is published every few years.

Publications are exchanged with about four hundred and fifty foreign institutions and with some two hundred domestic institutions.

\section{The Department of Minerals and Geology}

HE exhibitions in this department are grouped under two
main divisions: Minerals and Rocks. The first division is subdivided into fou parts :

(1) A systematic collection containing all the minerals found in New England arranged according to their composition.

(2) A synoptic collection illustrating the principal minerals of the world, also arranged according to composition. These two subdivisions occupy one whole room.

(3) A collection illustrating the minerals from the three most famous localities in New England and the local minerals found in the Metropolitan Boston district.

(4) A Gem Collection illustrating the little-appreciated semiprecious stones of New England and other gems.

The second division, that of Rocks, is made up of:

(1) A Petrographic collection, illustrating the various rocks of which New Englind is made.

()ㅡ A structural and dynamic Geological series illustrating the way these rocks occur and came into their present condition.

(3) An economic collection showing the various building stones, ores, and other products of the ground useful to man.

In addition to the exhibits a large study collection of minerals and rocks is maintained. Practically all are from New England. 'This is so arranged that any specimen is instantly available for study 
or comparison without reference to the catalogue. This collection has for its aim a representation of every mineral and rock from each locality where it occurs in New England.

The great variety of New England minerals as well as the striking beanty of many species is well brought out in the Systematic Collection. 'This is amplified by the collections from the famous mineral localities, in which are displayed the gorgeously colored tourmalines from Maine and Connecticut, accompanied by the wide variety of quartzes ranging from clear rock crystal to the deep purple amethyst. Many rare and unique specimens are contained in this collection which was described by the Keeper of the Mineral Collections of the British Museum as the best arranged and displayed collection he had seen in Anerica. The New England Gem Collection shows the great beauty and variety of these stoneswhich for some reason or other do not seem to have been discovered and appreciated by the local population. Here one may see a large number of cut stones showing every color-phase, and locality of origin, side by side with the uncut crystals of the same material.

The Economic Collection is usually a big surprise to our visitors, as the six New England states are not generally given due credit for their mineral wealth. 'The non-metalliferous section shows the many varieties of the king of building stones - granite. Our New England quarries have produced some of the most beautiful varieties of this famous building stone in the world. Vermont has been well known for her marble industry, and a complete set of polished slabs of this useful stone in its many colors is here to be seen. Slate and sandstone are also important building stones, while other important products are clay, for brick-making; talc, which has many uses and is extensively mined in Vermont; feldspar, used on porcelain, garnets and other abrasives, soapstone, mica, lime, and many other useful 


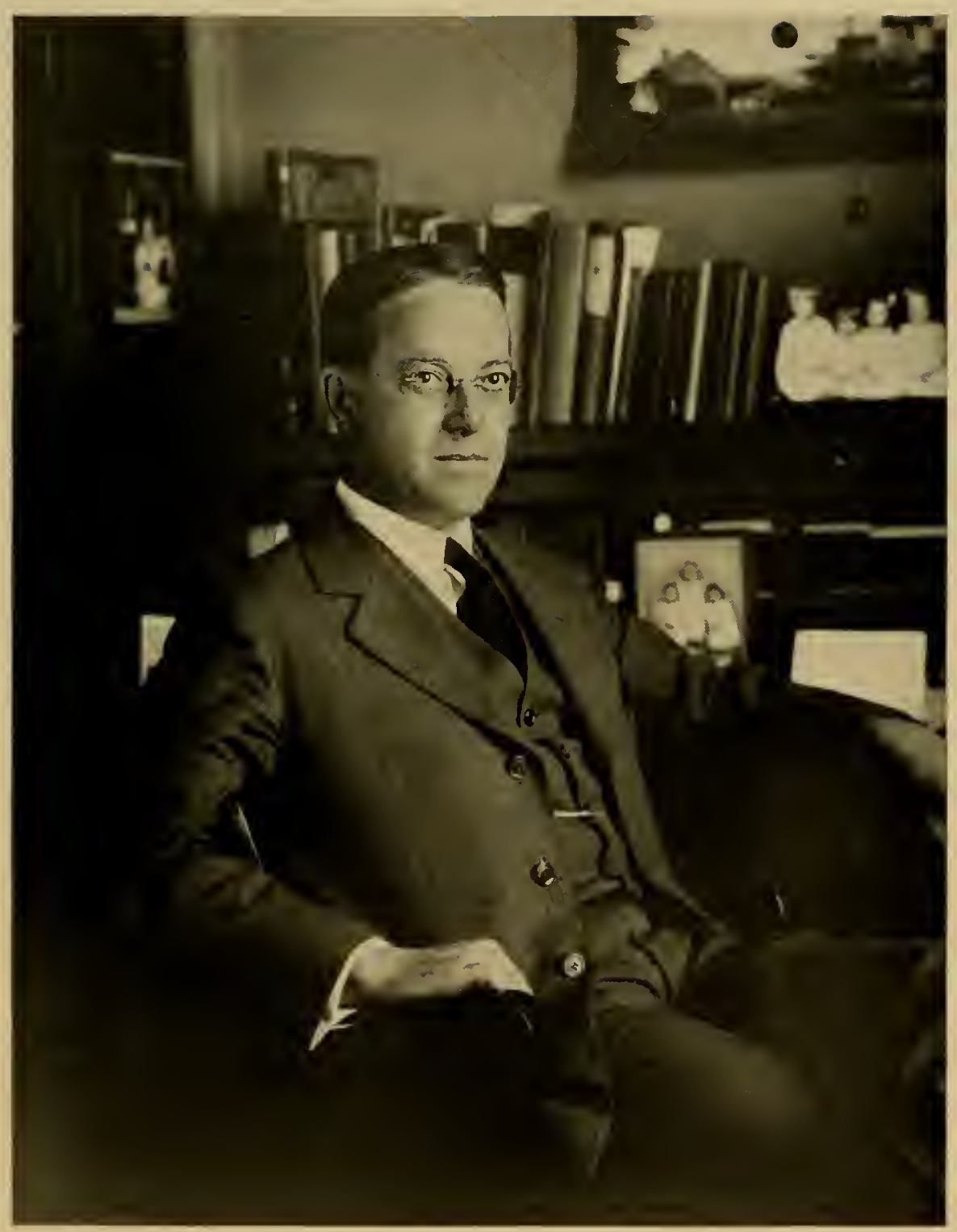

EDW ARD WIGGLESIVORTH

Director of the Muscum. 


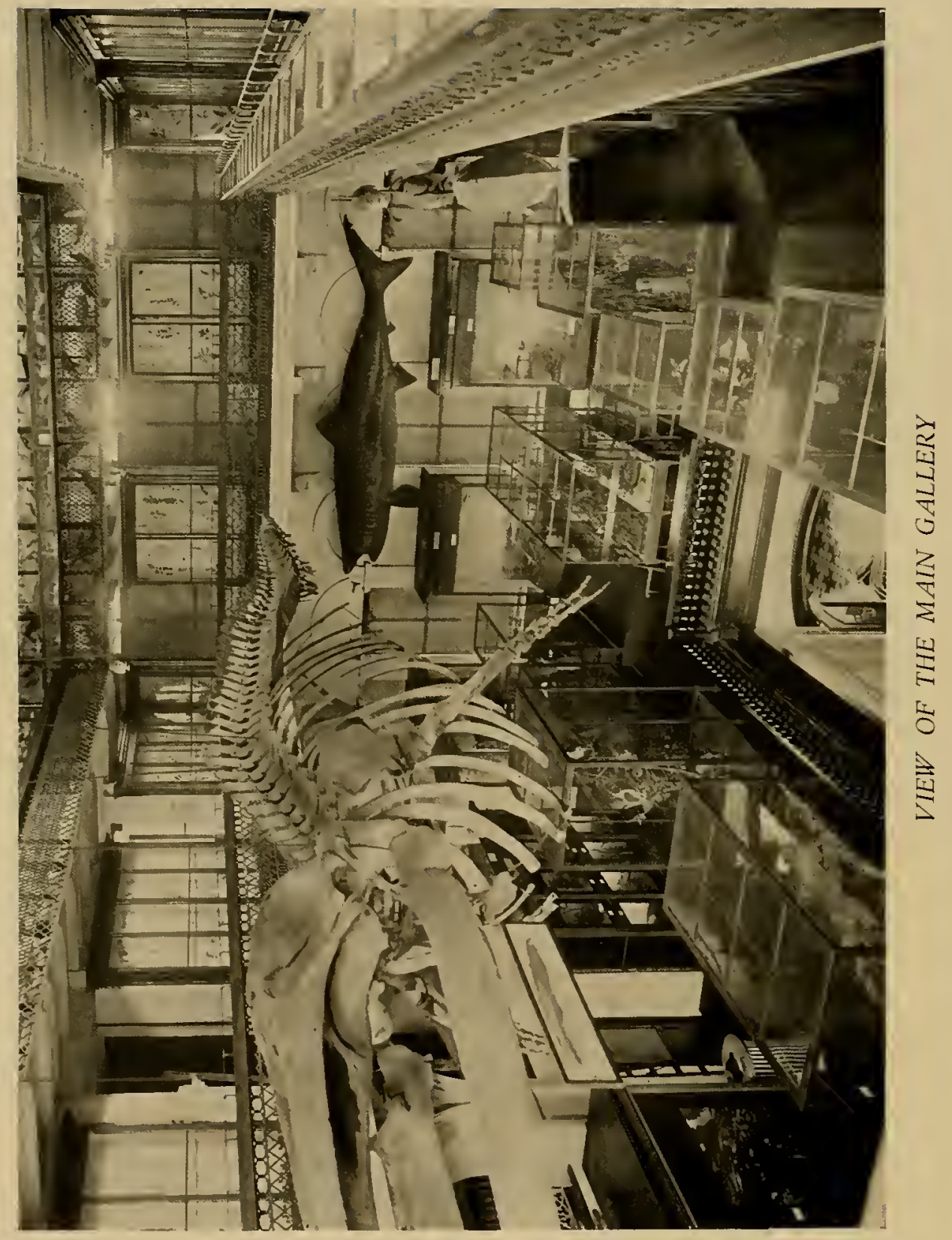


products which make a very imposing total. The metalliferous ores might well be considered as largely of historical interest, as many attempts liave been made in the past to mine various metals. Our iron ore wals once an important product. Copper, tin, zinc, lead, and even gold and silver have been produced at one time or another, although not always profitably. It is our aim to show the ore and, when possible, the finished product, from all the more important mines once operated here.

As regards individual features: our exhibit of Maine minerals is the bestknown and finest collection from this region in any Musem. All amethyst crystal from Denmark, Maine, is the largest and finest ever found in New England. A rose quartz from Maine, showing crystal, is one of very few such specimens. Our specimen from Auburn, Maine, of crystal of apatite is the second largest of this crystal ever discorered. We have a specimen of chrysoberyl which is the largest from New England. Our single beryl crystal from Grafton, New Hampshire, is probably the largest in any Museum.

\section{Fossils}

WEW Exalanus fossils are not spectacular, but are extremely most recent. The collection is arranged chronologically according to geologic age and therefore the development of life in this area can be seen. 'The oldest fossils found in New England are the primitive mollusks from the Cambrian rocks of Nahant and Cohasset, and early forms of trilobites from Georgia, Vermont. These are followed closely by the famous large trilobites from Haywards Creek in Braintree, a fine series of which is exhibited here including the original type specimen of the species. 'These fossils are no longer obtainable, as the locality has been used for commercial develop- 
ment. Other fossils of the same period are from Newport, Rhode Island.

'The succeeding periods known as the Ordovician and Silurian are represented by several forms of life including large cephalopods and small brachiopods from western Vermont, whose shells somewhat resemble clams or scallops of our present time. Most of these brachiopods became extinct ages ago, but it is interesting to note that a few have persisted until to-day, practically unchanged. 'Trilobites are also found in this period and the Society has one specimen, the only one of its kind ever found. 'This came from the Chapman Plantation in Maine. Another unique specimen is a fossil starfish from New England.

'The next great age is often called "The Age of Fishes," as it was at this time that the first vertebrate animals appeared. 'This is represented in New England by the fossil ferms from Perry, Maine, and a number of more lightly developed brachiopods from the same state. 'The succeeding coal-forming period, known as the Carboniferous, is represented in the collection by the giant rushes and tree ferns from Attleboro and Mansfield, in Massachusetts, and Narragansett, Rhode Island. From the next great period, the " Age of Reptiles," we have a most remarkable series of fossil footprints from the Connecticut Valley. Most of these were made by the dinosaurs, which attained, in some cases, tremendous size, but wc also have some rery small tracks thought to have been made by insects, and several "fossil showers" recorded by raindrop impressions on the same slabs of rock as the great dinosaur footprints. One of the rare dinosaur bones from this region is also in our collection. From rocks of the same period, also in the Connecticut $V$ alley, we have a large collection of fossil fishes.

The more recent "Age of Mammals" is represented by the fossil 
fruits and wood from Brandon, Vermont, and the shark's teeth, while bones, and crabs, from Gay Head on Marthas Vineyard.

The Glacial Period produced many mollusks from several localities, as Portland, IIaine, and Nintucket. The fossil tooth of a mastodon found during the excavation of the Cape Cod Canal is one of the striking specimens. From the Recent Period is a collection of bones found in the Indian shell heaps. 'These include at least three extinct animals, the Great Ank, the native Indian dog, and the giant mink.

\section{Botanical Department}

$A \begin{aligned} & \text { SIIALL collection of plants, presented by Amos Binney, was } \\ & \text { one of the first five contributions to the Museum of the Bos- }\end{aligned}$ ton Society of Natural History, according to the earliest accession book, which was started in 1830. This was the beginning of the present herbarium, which now contains many thousands of specimens, not only of flowering plants. but mosses, lichens, algae and fungi.

IIany early botanists of note were associated with the development of this herbarium, and some of them presented their collections to the Society. Noteworthy special accessions are the Spragne and the 'Thomas Taylor collections of lichens: the John A. Lowell collection of flowering plants. and many sheets from the collection of William Boott. More recently, the Reginald Heber Howe, Jr., collection of lichens, also the C. C. Kingman and the Joseph A. Cushman collections of miscellaneous plants have been acquired. The Society also owns a rare set of mounted algae, prepared and issued by Holden, Setchell \& Collins, consisting of many bound volumes of mounted plants.

These plants, with the numerous specimens collected especially for the Museum by Dr. Joseph $\mathrm{A}$. Cushman and others, are filed in steel and wooden cabinets, the New England plants being kept 
in separate cases. 'The flowering plants are arranged according to the sequence followed by Gray's Manual of Botany, edition 7 , and are filed by states, counties, families, genera, and species. Descriptions and pictures are useful for the identification of plants, but a collection of actual mounted specimens for comparison furnishes an invaluable aid to the serious study of botany.

The herbarium is open to members who are sufficiently familiar with dried specimens to receive benefit from their study, and to visiting botanists, research students, and authors, many of whom have drawn valuable information from the collections.

In addition to the herbarium, there is an excellent popular exhibit of selected, pressed specimens, painted in their natural colors. 'These plants are in the wall cases, on the gallery of the third floor, and in the rail cases bordering that gallery. The coloring was done by Mr. Frederic W. Grigg, and the arrangement is both useful and artistic.

\section{A Review of the Collection of Mollusca}

$\mathrm{T}$

HE department of mollusca was also blessed in the early days of the Society by having as officers two of the leading conchologists of that tine, Amos Bimey and Dr. A. A. Gould. 'Thework of these men, combined with the generous bequest of Miss Sarah $P$. Pratt, made the collection a very fine one for that time (1867). To this were added in 1891, the E. R. Mayo collection, and in 1899 , the E. W. Roper collection. 'These, with other additions, bring the catalogue number at the present time to 26,869 . From this number was selected the beantiful exhibit shown in the six glass cases in the synoptic room. A prominent feature of this exhibit is a series of 180 Blaschka models of cephalopods (squid, etc.) and nudibranchs (sea slugs). These, together with models of other marine invertebrates, 


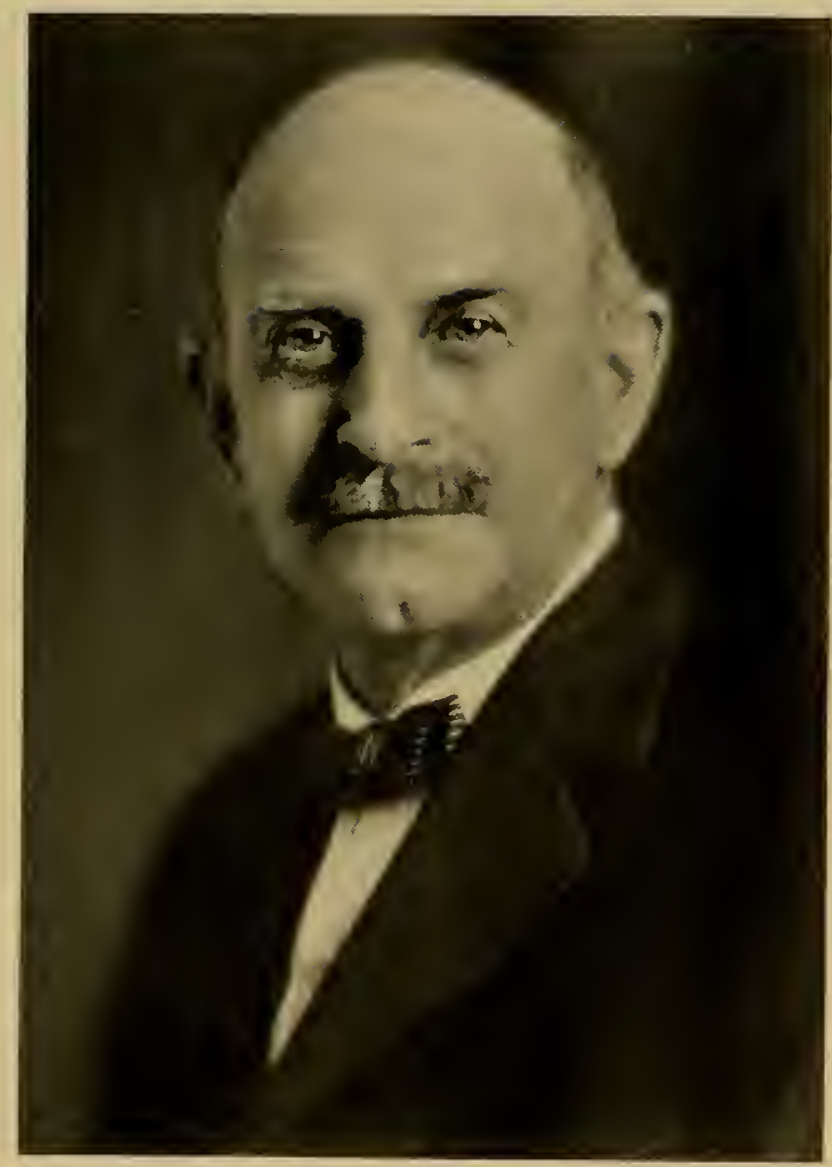

CHARLES W. JOHNSON

Curator, I 903, to prescht time. 
constitute the largest collection of this type of Blaschka models in any museum. One of the most interesting species is Argonauta compressa, $10 \frac{3}{8}$ inches in diameter, the largest specimen of this species of paper nautilus known. A study series was also arranged, most of the other extra New England material being sent to the Museum of Comparative Zoölogy at Cambridge.

There are on exhibition in the New England collection, about four hundred species, including thirty Blaschka models. 'This exhibit is supplemented by over one hundred beautiful colored drawings from life of some of the animals, by Mr.J. Henry Blake. The study series is represented by over 3,500 entries. 'The collection of New England mollusks from waters not exceeding fifty fathoms in depth is almost complete. What is now greatly needed to complete the series is a collection from depths ranging from one hundred to two hundred fathoms.

\section{A Review of the Insect Collection}

$\mathrm{T}$ HE Society, since its origin, has had among its officers and members some of the most prominent entomologists of the country. Dr.' Thaddens IV. Harris was one of the founders and gave lectures on insects before the Society as early as 1831. He was the first curator of insects in 1838. Dr. Samuel H. Scudder was curator of insects from 1859 to 1870 , and president from 1880 to 1886. Prof. A. S. Packard, Jr., was curator of crustaceans from 1863 to 1870. Edward Burgess was Secretary and Librarian from 1893 to 1900, and added many species to the collection.

A collection of great value is that made by Dr. Harris during a period from 1820 to 1838 . 'This is of special interest, as it gives some knowledge of the insect fauma in the vicinity of Boston one hmdred years ago. This collection was the basis of Dr. Harris' classic 
work, The Inscets of Mrassachusetts Injurions to Vegetation, published in 1841, with a second edition in 1852 and a third illustrated edition in 1862 . The collection was purchased by the Society in 1858 . It has always been kept apart from the other collection of insects, and contains about 4,660 species and about 9,750 specimens. It represents the oldest insect collections extant in the United States and contains the types of about 140 species.

In regard to his collection of insects, Dr. Harris, on March 8, 183\%, wrote to Mr. C.J. Ward as follows: "My object in making a collection, and for this purpose asking the aid of my friends, has not been merely personal gratification; it has been my desire to add something to the cause of Science in this country. ... Even should death surprise me before the results of my labors are before the public, I shall leave an extensive, well-arranged and named collection, which, from the care bestowed upon it, will be in a condition for preservation and will remain as a standard of comparison when I am gone."

In 1903 was hegun a study collection of New England insects, the old collection being largely on exhibition, having been badly injured by the effect of light. Repeated trips to various parts of New England, with intensive collecting on Mount Washington, New Hampshire, IIount Desert, Maine, the Berkshires, and Nantucket, Massachusetts, together with the coöperation of members and others, have been largely responsible for the exceptional status of the Society's present collection.

The only large recent gift was the collection of the late Howard Lee Clark of Providence, Rhode Island, presented to the Society in 1927 by Mrs. Clark. This handsome collection of moths and butterflies contained about 1,100 species, represented by orer 7,200 specimens, mainly from New England. 
The result of this field work, including the assistance from members and others, has been most gratifying, as shown by the following figures:

Coleoptera
Diptera
Lepidoptera
Hymenoptera
Hemiptera
Homoptera
Neuropteroids, etc.
Odonata
Orthoptera, etc.
Total

Coleoptera

Lepidoptera

Hymenoptera

Hemiptera

Homoptera

Neuropteroids, etc.

Odonata

Total

\begin{tabular}{rr} 
Species & Spceimens \\
2,860 & 12,830 \\
2,836 & 22,170 \\
1,725 & 12,145 \\
1,385 & 7,893 \\
377 & 2,777 \\
341 & 2,045 \\
295 & 1,388 \\
123 & 688 \\
101 & 901 \\
\hline 10,043 & 62,837
\end{tabular}

The above figures include about 550 types, but do not include the Harris collection, nor the exhibition series contained in sixtyfour glass-covered cases, $24 \times 30$ inches. In 1880, the New England collection contained 3,000 species and 7,600 specimens.

The introduction of many injurious insects into this country in various ways, the destruction these have caused, and the introduction of their parasites to aid in controlling them, all serve to make a study of Entomology both practical and imperative. We must know our insect friends (and many are not aware that we have insect friends). We must know which to save and which to destroy, when to kill and when not to kill the injurious species, so that the parasite species may have a chance to increase. Millions of parasites are destroyed that could and should be saved. This is a great problem, as it takes years to restore "Nature's balance," when an injurious insect has been introduced into a new region without its natural enemies. 'This is especially true under existing conditions, when the destruction of the forest, clearing, draining, and stream pollution have locally destroyed many of the natural conditions faror- 


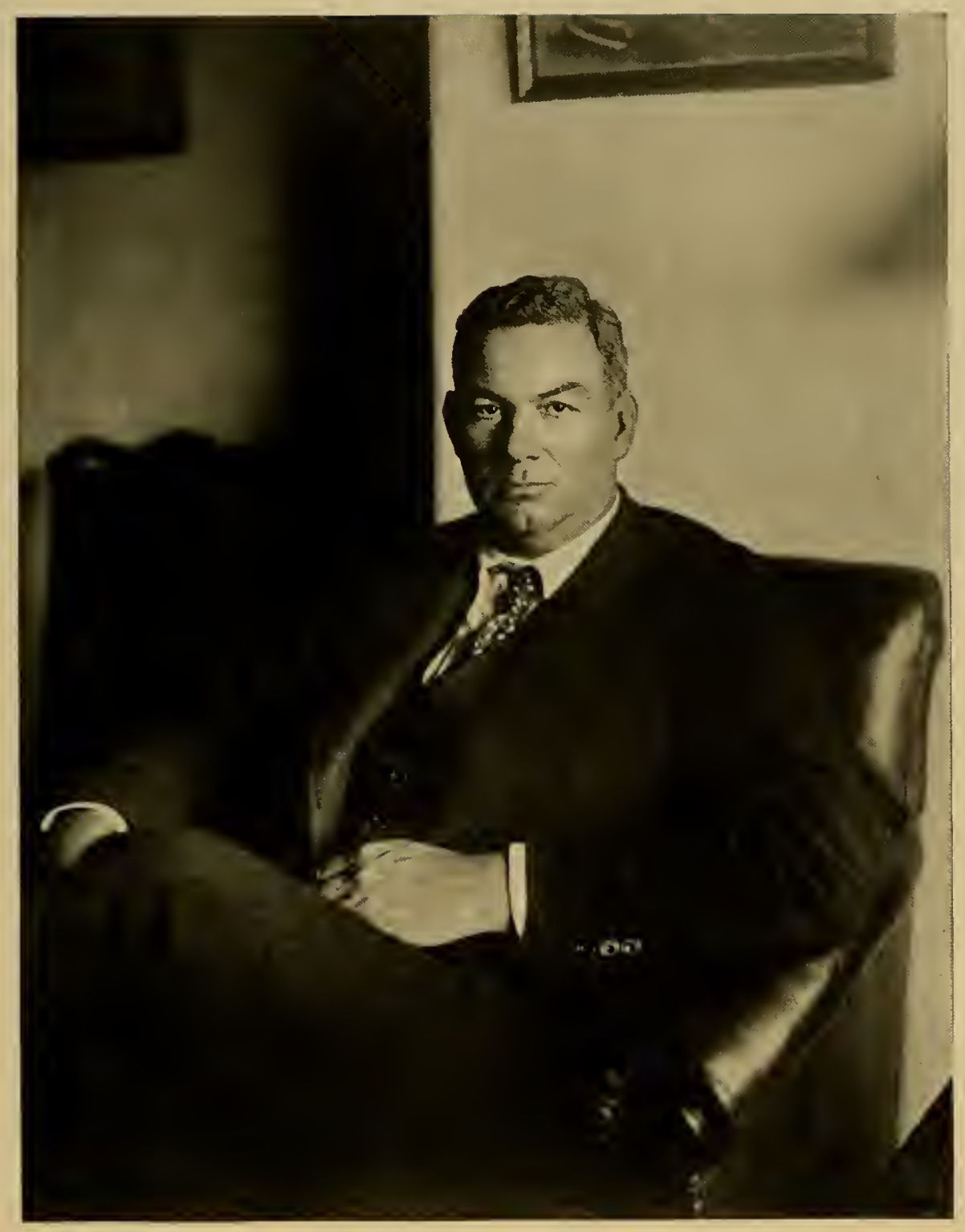

THOMAS BARBOUR

President, 1925-1927. 
96 Boston Socicty of Natural History

able for insect life and have practically exterminated many of our native species.

With these facts before ns, it is erident that we must make as thorougl a study of the insect fauma of our region as possible, and build up a collection that shall meet the demands of the present and future students of Entomology.

\section{Department of Marine Intertebrates}

$W_{\text {land. do not attract as much popular attention as the better }}^{\text {Hile marine invertebrates, especially those of New Eng- }}$ known group of animals. many of them do present a brilliant display of color and a great variety of patterns which appeal strongly to one's interest. The corals, sea-fans, starfishes, and mollusks in the Museum are numerous, and many of the soft-bodied animals are represented by the famous Blasclika glass models. These were prepared by the makers of the famous glass flowers in Cambridge.

As it is the policy of the Musem to emplasize New England life chiefly, one room is deroted entirely to New England invertebrates. Another is devoted to it synoptic collection of specimens including many from foreign waters. This plan allows the study of a limited area as well as a comprehensive riew of related forms from many parts of the world.

The educative value of marine invertebrates is rery great. It is probable that life itself began as a single-celled plant or animal in the watcr, and throughout the long history of the earth, the multitude of invertebrates in the oceans and shallow inland seats has been slowly changing to higher forms, thus presenting a vivid and almost complete picture of the development of animal life. either through living or fossil organisms. The collections are arranged to show these instructive steps and to illustrate the general principles 
of erolution, which, after all, is only the more or less progressive development of low and simple forms to the higher and more complex.

Iarine invertebrates play an important practical part in our industries. Millions of dollars are invested in the culture and marketing of oysters and other mollusks. I cobsters are getting scarce on the New England coast and several species of crabs have come into faror through the shortage. All these, with hosts of other invertebrates, are shown in the Museum.

Foraminifera, one-celled animals which live in great numbers in the ocean, are represented in the cases by many species. 'The discovery that certain fossil foraminifera often indicate the presence of oil in the rocks has added interest in these microscopic animals because of their practical value and curions structure.

Artists and designers may find, in the specimens exhibited, many patterns and useful suggestions which can be incorporated in their work.

Habitat groups, showing crabs and other invertebrates in their natural surroundings, occupy a part of one room. Interesting biological studies, such as the regeneration of lost parts in lobsters and starfishes; the opening of an oyster by its enemy, the starfish; and the peaceful association of several different animals, with common benefit to all, are illustrated in the exhibition cases.

Historically, some of the most noted scientists in the United States have been associated with this department or have taken an active interest in its development, and some of the earliest contributors to the museum, dating back nearly one hundred years, were authorities on marine invertebrates. The elder Agassiz; several of his pupils, such as E. S. Morse, and .J. Henry Blake, as well as Alexander Agassiz, who continued his father's work at Harvard, did splendid work with this group of animal life. 'The names of 


\section{$98 \quad$ Boston Society of Natural History}

Alpheus Hyatt, a former director of the Museum; A. E. Verrill, of Yale University; Van Vleck, Rathbun, A. S. Packard of Brown University, J. A. Cushman, and Miss Mary J. Rathbun, now of the National Museum at $W$ ashington, frequently appear in the records of the Museum and on the labels of specimens which some of them obtained by extensive dredging.

Although two hundred fathoms have been arbitrarily selected as the depth limit for New England work, most of the material in the collections has come from the shore or from water not deeper than fifty fathoms. Dredging operations in from one hundred to two hundred fathoms would undoubtedly produce abundant, valuable, and much desired species, but such work requires elaborate and expensive equipment. As it is, we have several thousand specimens in the various divisions included in the term marine invertebrates, the result of early collections and the work of more recent curators.

\section{Fislies}

THERE are over 340 species of fish in New England of which about 220 are mounted in our collection, leaving about 120 fish still to be acquired. 'Thirty-eight families are represented. Selachians are well represented. 'There are about a dozen sharks excellently mounted, including Basking Shark, 'Thresher Shark, Great Bhue Shark, Man-eating Shark, and Mackerel Shark. 'The Scombridae, or mackerel-like fishes, are represented by about a dozen species, and there are also numerous species of flounders.

The game fish are all represented: salmon, pickerel, perch, bass, catfish, etc., as well as such economically important species as cod, pollock, haddock, halibut, and smelt. 


\section{The Museum as it stands To-day}

There are three habitat groups of fishes: lake, rocky ocean shore, and muddy pond. 'The lake group contains small-mouthed black bass, landlocked salmon, and brook trout. 'The muddy pond groups contain yellow perch, white perch, pickerel, hornpout, and smallmouthed black bass. 'The marine group contains cunner, tautog, cod, and daddy sculpin.

We have also a number of more unusual species, such as the Opah, Lookdown, 'Tripletail, and Filefish, which are of great rarity in these waters. The fish collection is varied and extensive because of the strategic position of the New England states where a northern and a southern fauna overlap, southern species of ten wandering as far north as the south shores of Cape Cod in the Woods Hole region, and northern species coming into the Gulf of Maine.

A bout 140 species are present in the study collection. Many of these were apparently used by D. Humphreys Storer and figured in his classic, Fishes of Mrassachusetts, published in 1867; and in publications of the Society.

From 1843 to 1849 Dr. Jeffries Wyman was curator of fishes; from 1859 to 1870, Dr. Frederick W. Putnam.

\section{The Reptile Collection}

THE number of species of reptiles and amphibians found in 1 New England is not large, owing to the fact that the main habitat of these animals is in the tropies, their number decreasing as they extend northward. The forms recorded from New England include ten salamanders, twelve frogs and toads, eighteen turtles, sixteen snakes, and one lizard. 'The Society's collection contains representatives of nearly all of these species. Until very recently it has been impossible to exhibit reptiles and amphibians in an attrac- 
tive manner, but with the newer methods of preparation, it is hoped that this group can soon be made as interesting to the public as the birds or mammals.

'The study collection, which is increasing in size each year, now contains approximately six hundred specimens, all from New England. There are abont three hundred specimens of reptiles and three hundred amplibians. 'The collection is now of sufficient size to be of distinct vilue to any student of New England herpetology. Perhaps our most famous specimen from an historic and literary standpoint is a shell of a Blandings 'Tortoise, captured in the Concord River and presented to the Society by Henry David 'Thoreatu. Other forms of especial interest are the great Leatherback Sea 'I'urtle, the largest species of turtle now living, specimens of which are occasionally captured off our coast; the Banded Rattlesnake and Copperhead, the only two renomous snakes found in New England; the rare Spade-foot 'Toad, and a Muhlenberg's 'Turtle from Rhode Island, collected by Alexander A gassiz.

We have one habitat group on exhibition. It shows the Snapping 'Turtle, our largest fresh-water turtle, ilhustrating the nethod of laying its eggs.

As the interest of the public lies in these habitat groups and specimens for exbibition rather than in the study collections, our present neccssity lies in the enlarging of this exhibition collection. In the course of time we hope to have a series of groups illustrating the development and growth of various reptiles and amplibians, their structure, their environment, and their habits. 


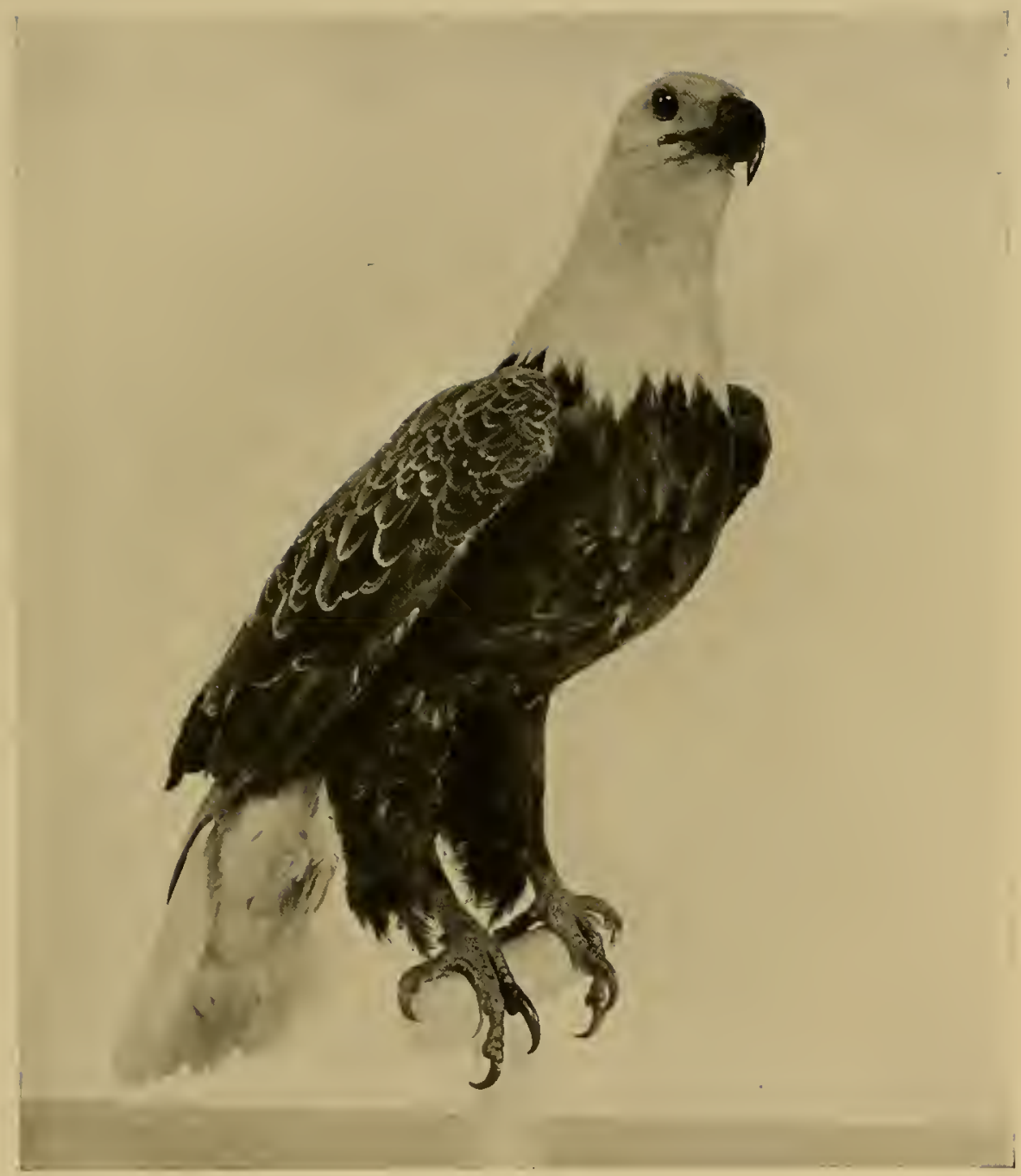

\section{$B A L D$ EAGLE}

Twenty-five years old. Taken from nest in May, 1827, near Bangor, Maine, and presented to Mr. George Read, of Roxbury, who kept her twenty years. Selected by Audubon for the model for his painting in his "Birds of America." 


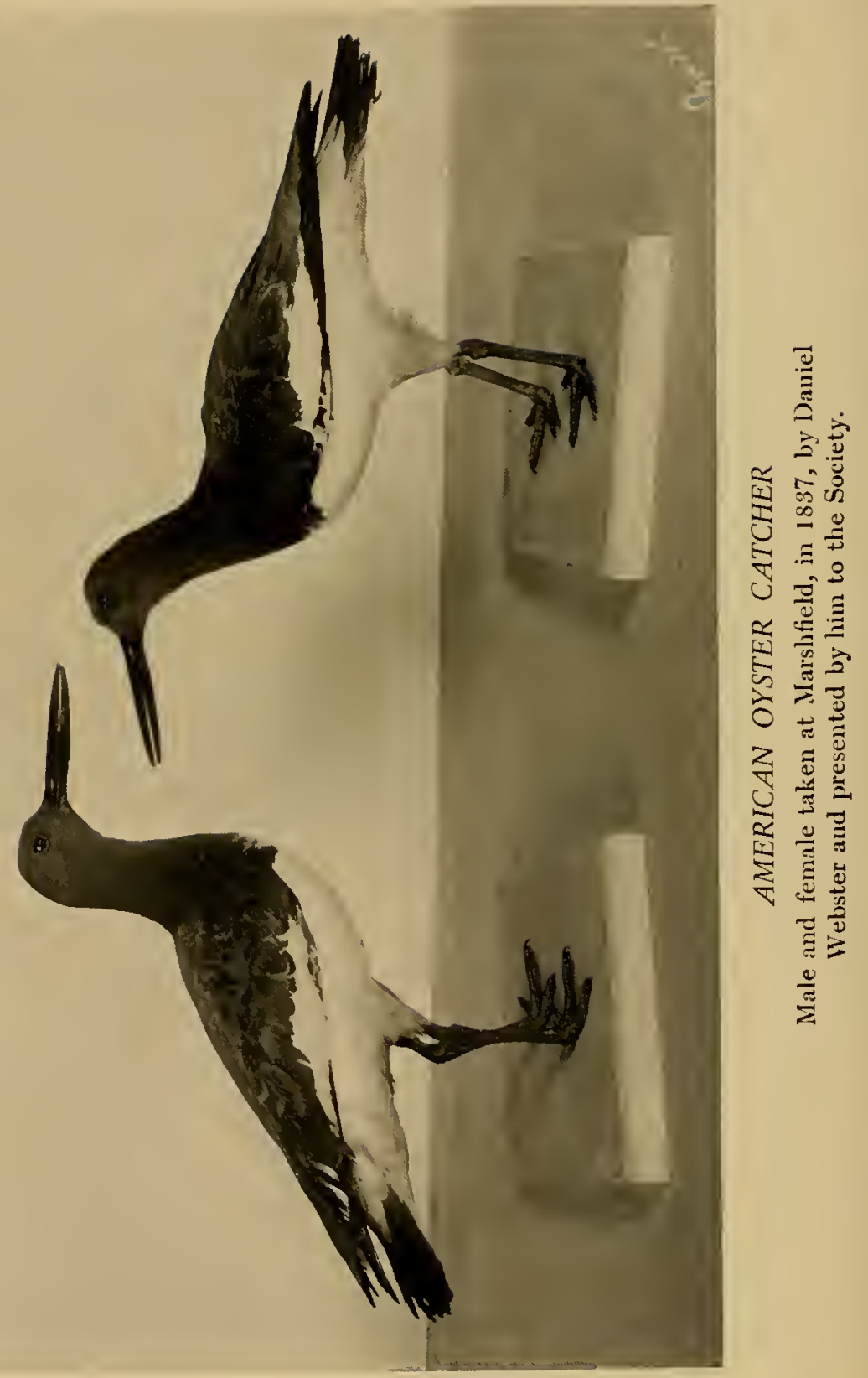




\section{The Museum as it stands To-day \\ The Ornithological Department}

103

1 HIS department, with its mounted birds, its habitat gromps, the most complete department of the Museum.

Some 350 species momnted and on exhibit in the bird room form a collection second to none in its arrangement, display, completeness, and excellent taxidermy. Among these are all the breeding birds of New England and most of the migrants and accidental visitors, some of them unique, such as the WV hooping Crane, Eskimo Curlew. Passenger Pigeon, Barnacle Goose, Labrador Duck, Mountain Plover, Black-capped Petrel and Pink-footed Goose. Also exhibited are the only New England records of Lark Bunting, Blackthroated Gray $W$ arbler, Audubon Warbler, and Varied 'Thrush. In most cases several individuals of each species are on exhibit. 'This offers opportunity for quick comparison of plumages which vary with the sex, age, and color-phase of the bird.

Over seventy of the commoner birds of the New England region are demonstrated in habitat groups. About half of these are in wall cases, artificially illuminated, and each accompanied by a label giving necessary data relative to the bird exhibited. These comprise the birds which one meets in almost any ramble through the comntry, such as Brown 'Thrasher, Rosc-breasted Grosbeak, Barn Swallow, Scarlet 'Tanager, Kingfisher, House Wren, and Red-breasted Nuthatch. A habitat group of winter birds of the Massachusetts coast illustrates such visitors as Murre, Dovekie, Razor-billed Auk, and Purple Sandpiper. 'Two other habitat groups, representing the birds on fall migration through the marshes and beaches of Ipswich, Massachusetts, show birds such as Semipalmated Plover, Yellow- 
104 Boston Society of Natural History

legs, Hudsonian Curlew, and, in fact, all the common shore birds which visit the coast of New England in autumn.

The study collection, carefully kept in insect-proof and dust-proof cases, contains almost seven thousand skins, representing about 350 species, including nearly all the birds known to visit New England. This collection is unique, and is particularly valuable for any one engaged in the scientific study of the birds of this region.

A collection of about 1,450 sets of birds' eggs representing 243 species is maintained by the Society. It contains the eggs of practically all the breeding birds of New England, ind, so far as possible, the eggs of those birds which migrate through New England or risit the region only occasionally, as accidental visitors.

Both the egg collection and skin collection are housed in the most modern and efficient of museum cases which are insect proof and dust proof. Each set of eggs is kept in a separate air-tight, hermetically sealed, glass-topped box. Both these collections are of great scientific value, and both collections are available for study to any properly introduced person.

The synoptic collection of vertebrates contains some four hundred species of foreign birds, illustrating the more interesting types of birds and showing variation in form, plumage, and adaptations.

A collection of several thousand mounted foreign birds, known as the La Fresnaye collection, completes the list of the Society's widely varied ornithological specimens.

\section{Mammals}

THERE are about 140 species of mammals in the collection. 1 Of these, sixty came from New England, whose species are almost all represented. About twenty skeletons are on exhibit and 


\section{The Museum as it stands To-day}

a greater number of skulls and parts of skeletons. Practically all the New England mammals are represented in the study collection, some groups, as the mice, shrews, moles, and squirrels, quite completely. This collection is well arranged and easily available for reference. The monnted material is well labelled and there should be no difficulty for a visitor to identify any New England manmal he has seen by inspecting those animals on exhibit.

The mammal exhibits which attract most attention are the artificially illuminated habitat groups placed around the Main Hall. These are particularly instructive and are accompanied by labels giving ecological and other information about each species. These include such species as bats, weisel, woodchuck, muskrat, raccoon, mice, shrew, mole, porcupine, and fox. On the lower floor is a series of habitat groups showing seasonal rariation in mammal pelage. The animal used is the Eastern Varying Hare. Four cases show the coat of the animal in spring, summer, fall, and winter.

A number of the larger marine mammals, the Cetaceans, from New England coastal waters are displayed in the Main Hall. These include Common Dolphin, Blackfish, White Whale, Pigmy Sperm Whale, Grampus, and Common Harbor Porpoise. A skeleton fortyeight feet long of a Finback Whale hangs in the center of the Main Hall.

A whale and whaling exhibit is placed in one comer of the Hall. This includes jaw-bones, whaling instruments, and whale products such as ambergris and baleen. There are also some teeth and a fine collection of scrimshaw work.

One room of the Museum is deroted exclusively to New England furs. About forty skins are demonstrated, showing results from various treatments and dyes, with a label indicating the compara- 
I06 Boston Society of Natural History

tive value of the fur. In most cases a mounted specimen of the animal which provides the fur is represented.

In addition to the economic side, illustrated by the display in the fur room, and ecological data on various habitat groups, all the game animals and those hunted for sport in New England are mounted and on exhibit

\section{The Taxidermy Department}

$\neg$ HIS, strictly speaking, does not have any exhibition. It is one 1 of the "behind the scenes" departments without which the vertebrate animals would make but a sorry display. A wide range of work calling for great versatility is done here by the Preparator and his Assistant, who are constantly on the lookout for new and improved methods. One day, the work may be skinning and mounting a new sparrow to replace a faded specimen, another day, it may be painting a landscape to serve as a background for a new group. Again, plaster casts may be the day's order, or a celluloid iridescent coating may be in process to put the finishing touches on a new fish, or a celluloid cast of a snake may be in the making.

A competent taxidermist for this Museum must have a good knowledge of Zoölogy, must be able to mount birds, mammals, reptiles, and fishes, must be something of an artist and sculptor, as well as a carpenter, plaster worker, and sometimes a good shot with a gun for collecting purposes. Recently the celluloid method of reproducing reptiles has forced us to become familiar with the chemistry involved in working this medium. 'The demand for habitat groups means that thousands of leaves must be cast in wax, one by one, painted, and attached to stems to reproduce faithfully the proper setting for the animal shown in the group. Flowers are likewise needed, and this calls for expert glass blowing. A well-equipped 


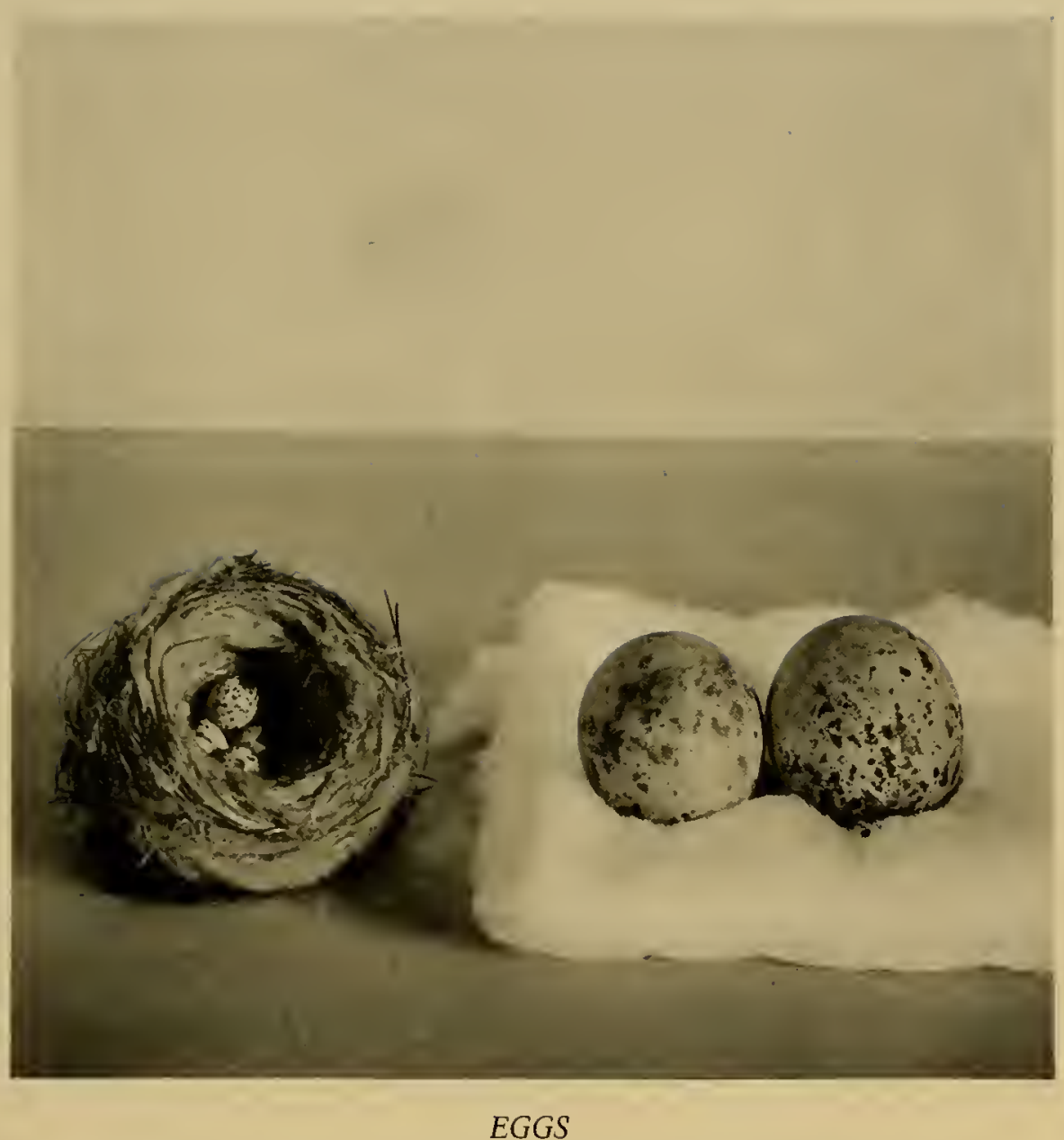

Those in nest are of Yellow Warbler, the other two of Red-tailed Hawk. Found and presented to the Society by Henry D. Thoreau. 


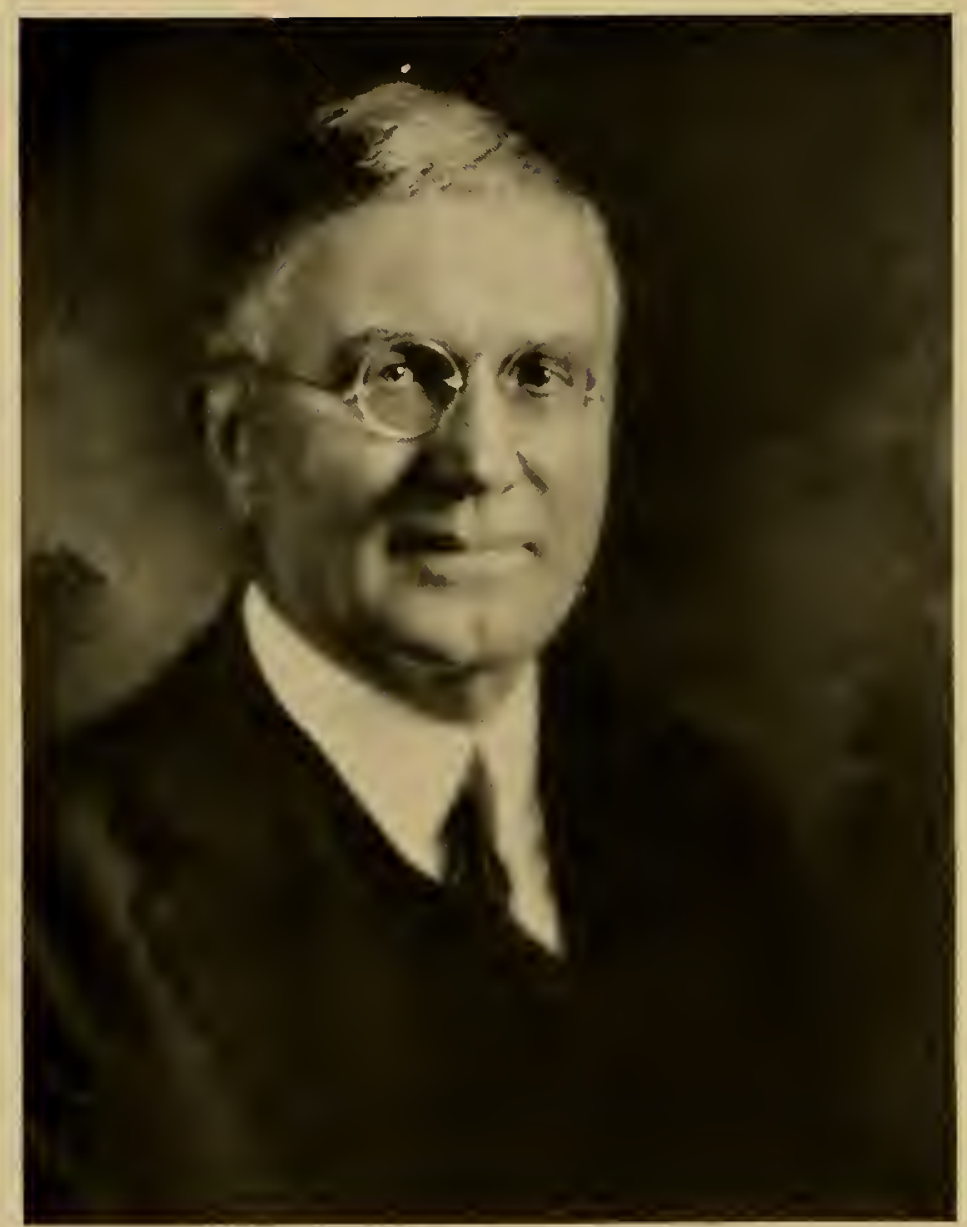

CHARLES H. TAYLOR

President, 1927, to present time. 


\section{The Museum as it stands To-day}

workshop in this department is important, and several mechanical pieces of equipment are in use, such as air brushes, heaters, drying cabinets, electric refrigerator to keep specimens until they can be mounted, fixing baths, and so forth. Versatility and variety are the essence of the taxidermist and, correspondingly, of his tools and apparatus. 


\section{JEFFRIES WYMAN}

Died September 4, 1874

THE wisest man could ask no more of Fate

1 Than to be simple, modest, manly, true, Safe from the many, honored by the Few;

Nothing to court in world, or church, or state,

But inwardly in secret to be great;

To feel mysterious Nature ever new,

'To touch, if not to grasp, her endless clew,

And learn by each discovery how to wait;

To widen knowledge and escape the praise,

Wisely to teach because more wise to learn;

To toil for Science, not to draw men's gaze,

But for her lore of self-denial stern;

That such a man could spring from our decays

Fans the soul's nobler faith until it burn. 


\section{III \\ PLANS FOR THE FUTURE}




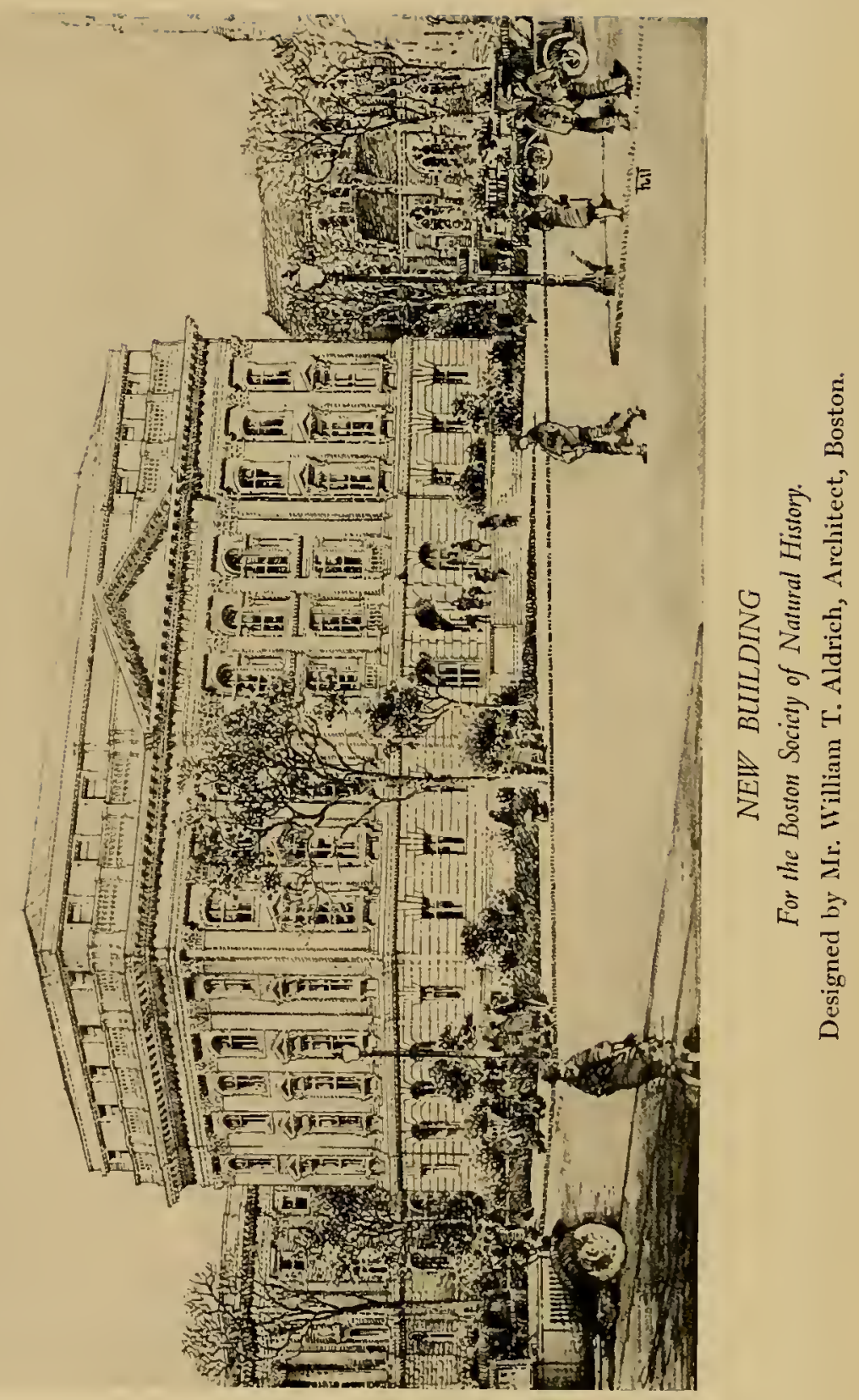




\title{
PLANS FOR THE FUTLIRE
}

\section{(Our Present Building not Fireproof)}

\begin{abstract}
$A$ PAR'T from the grave risk to our collections involved in the $A$ fact that our present building is not fireproof. our immediate task is to escape from the congestion caused through lack of accommodation for our collections and for the students who seek information from them. We are confronted with the vital necessity of doubling the space of our MIuseum. A drawing of our new building, designed by Mr. William 'T. Aldrich of Boston is shown on the opposite page. It may be left to speak for itself.
\end{abstract}

\section{Education}

UR Society, as the reader will have seen, has inherited an important function of lealership in the educational field. Horace MIann, a prominent member of our Society, who, when President of the Senate of Massachusetts, became, in 1837, the first Secretary of the State Education Department, summed up the true nature of Education in words upon the sagacity and insight of which it would be difficult to improve. He said:

"All intelligent thinkers upon the subject now utterly discard and repudiate the idea that reading and writing, with a knowledge of accounts, constitute education. The lowest claim which any intelligent man now prefers in its behalf is that its domain extends over the threefold nature of man; over his body, training it by the systematic and intelligent observation of those benign laws which secure health, impart strength, and prolong life; orer his intellect, invigorating the mind, replenishing it with knowledge, and cultivating all these tastes which are allied to virtue; over his moral and religious susceptibilities also, dethroning selfishness, enthroning 
conscience, leading the affections outwardly in goodwill toward man, and upward in gratitude and reverence to God."

'The crux of the educational problem, as Agassiz so clearly realized, is the supply of thoroughly competent teachers for the schools. The solution of this problem depends upon the discovery and training of the right sort of talent. 'The necessary supply of talent is there but, as far as New England is concerned, this talent is to a very large extent running to waste for lack of encouragement and scientific training. We have to put a stop to this waste and, in so doing, render a vital service to the cause of Education. The fact is that Natural History is a Cinderella among the subjects in the Educational syllabus instead of being, as it should be, an essential part of the foundation of all Education. We have temporarily lost the sense of proportionate value which was so clear to Agassiz, Emerson, Eliot, and many other great Educators.

In a summary of replies to a questionnaire sent by the Committee on School Museum Relations of the American Association of Museums to a number of institutions (classified as museums of art, 23; museums of science, 17 ; museums of history, 9; other or general museums, 12. 'Total, 61), twelve museums report regular arrangements for the help of teachers, but in only one or two instances are the arrangements at all formalized. It is not stated how many of these twelve museums belong to the Sciences and how many are in the categories mentioned above. As far as New England is concerned we maystate with confidence that our educational facilities may be greatly increased by teaching public school teachers how to use the Museum in their work. It would be as practical to attempt to train a Medical student without a hospital as it is to turn out a competent teacher of Natural History without knowledge of how to nse a Museum. 
The new building will give us scope, sadly lacking at present, for many activities.

Our new Auditorium will be in constant use for lectures and kindred purposes. People have to be turned away from our lectures at present, owing to lack of accommodation.

Our Library, greatly enlarged, with well-arranged accommodation for readers, will fulfil a much-needed public service. With increased room it will be possible to add to our list of books the works which are wanted to make our Library complete and up-to-date in every section.

We shall have better Laboratories for our Staff. There should be also class-rooms for instructional purposes where teachers from the Schools may bring their classes and where Museum material may be used for demonstrations. We believe, in general, that this policy is better than many small and inadequate circulating collections.

A new department will be devoted to exhibits bearing on Economic Biology and illustrating the basic industries of New England which depend so largely upon the fauna of the Ocean.

Funds will be set aside for publishing the results of our researches, also New England Guides to Natural History.

Grants will be given for each of the New England states to be awarded to promising young naturalists who show sufficient ability to profit by a thorough course of instruction in the Museum and in the field.

Prizes will be given to encourage original work.

Children's classes will be held.

Radio talks will be given.

Collections suitable for instructional purposes in schools and similar institutions will be provided. 


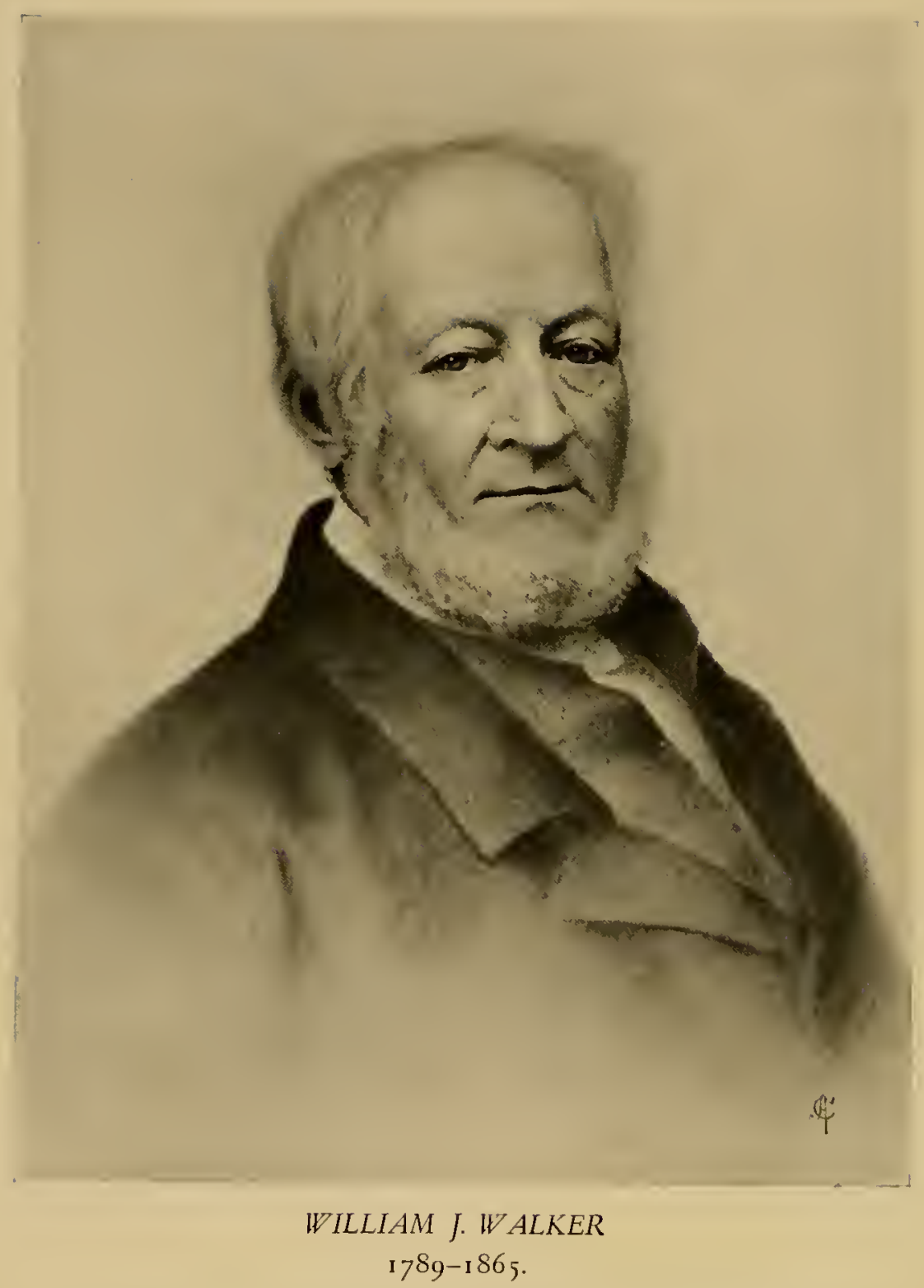

Generous benefactor of the Boston Society of Natural History. 
Dovetailed into our Museum activities will be much exploration work which in many departments is at present incomplete. This work will be entrusted to competent members of our Staff. 'The reader may remember that the first scientific surrey of the State of Massachusetts was undertaken in 1837 at the instigation of $\mathrm{Mr}$. George B. Emerson - then President of our Society - and of his colleagues. At the request of Governor Everett, endorsed by both houses of the Legislature, this survey was carried out under the direction of Mr. Emerson, but, as has been said, a great deal of exploration work remains to be done throughout New England.

We venture to believe that there are few ways in which a man may confer such lasting benefits and such happiness on so large a mumber of people as in providing facilities for an understanding of the wonderful ways of Nature. 



\section{B. LIpdike \\ The Merrymount Press \\ Boston}


- 




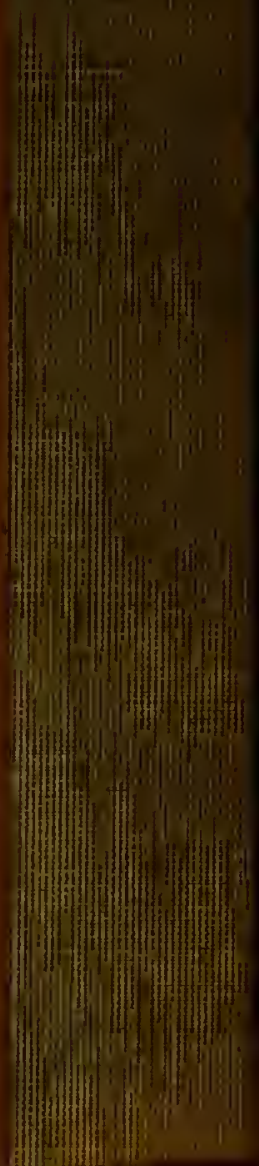

